\title{
Chapter
}

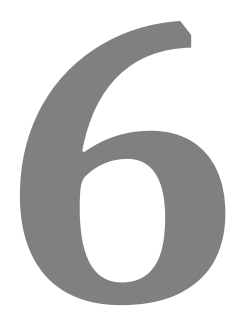

\section{CHIRAL SEPARATION FOR ENANTIOMERIC DETERMINATION IN THE PHARMACEUTICAL INDUSTRY}

\author{
Nelu Grinberg, Su Pan
}

\section{Contents}

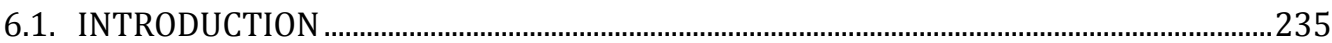

6.2. ENANTIOMERS, DIASTEREOMERS, RACEMATES …........................................................236

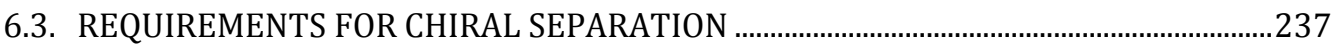

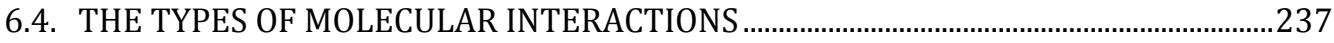

6.4.1. Chiral separation through hydrogen bonding ......................................................237

6.4.2. Chiral separation through inclusion compounds..................................................243

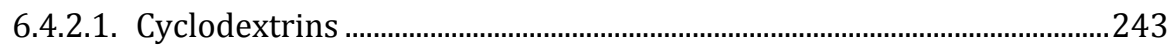

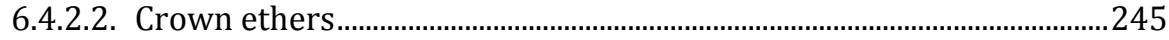

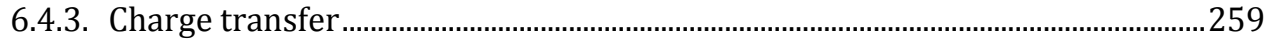

6.4.4. Chiral separation through a combination of charge transfer, hydrogen bonding and electrostatic interactions ..................................................................26 260 


\section{Chapter 6}

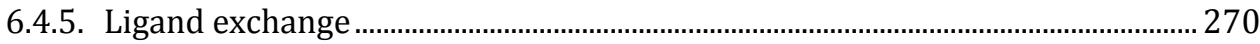

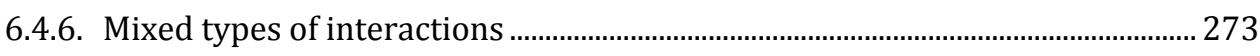

6.4.6.1. Polysaccharide phases ................................................................................ 273

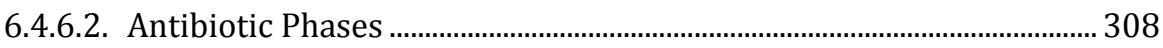

6.4.6.3. Protein Phases .............................................................................................. 312

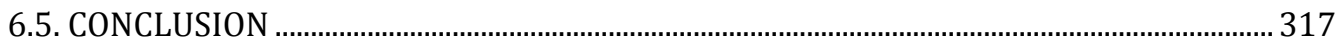

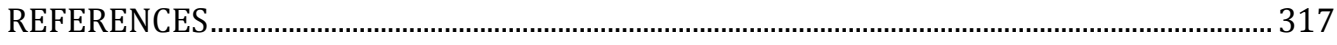




\subsection{INTRODUCTION}

Chirality plays a major role in biological processes. Enantiomers of a bioactive molecule often have different biological effects, as their pharmacological activity may reside in only one enantiomer of a racemic mixture. In some cases, enantiomers may have qualitatively similar pharmacological activity, but different quantitative potencies, while in others one enantiomer can be potentially toxic. Since drugs that are produced by chemical synthesis are usually a mixture of enantiomers, there is a need to quantify the level of enantiomeric impurity in an active pharmaceutical ingredient (API) [1].

The history of enantiomeric separation starts with the work of Pasteur. He discovered in 1848 that the spontaneous resolution of racemic ammonium sodium tartrate yielded two enantiomorphic crystals. Individual solutions of these enantiomorphic crystals led to levo and dextro rotation of polarised light. Because the difference in optical rotation was observed in solution, Pasteur suggested that, like two sets of crystals, the molecules are mirror images of each other and the phenomenon is due to molecular asymmetry [2].

While Pasteur made the historical discovery, subsequent advances in the resolution of enantiomers by crystallisation were based on empirical results. Several attempts to separate enantiomers using paper chromatography were met with unreliable results. In 1952, Dalgliesh postulated that three points of simultaneous interaction between the enantiomeric analyte and the stationary phase are required for the separation of enantiomers [3].

Developments in the field of life sciences and in the pharmaceutical industry brought enantiomeric separation to a new level. In the late 1950s/early 1960s, many drugs were synthesised and used in a racemic form. An example with tragic consequences is the use of thalidomide, a sedative and sleep-promoting drug used in the early 1960s which produced severe malformations in the newborn babies of women who took it in the early stage of pregnancy. Later, it was demonstrated that only the $(S)$-enantiomer possesses teratogenic properties [4].

The introduction of gas chromatography provided a stimulus to the field of enantiomeric separation. In 1966, a group from the Weizmann Institute of Science in Israel reported the first successful separation of enantiomers using gas chromatography (GC). 
In a letter addressed to Emanuel Gil-Av after the publication of the first separation of enantiomers by a chiral GC stationary phase [5], A. J. P. Martin wrote: "As you no doubt know, I had not expected such attempts to lead to much success, believing that the substrate-solvent association would normally be too loose to distinguish between the enantiomers." At the time, there were only a few reports on the separation of enantiomers using chromatographic methods. Later developments in high performace liquid chromatography (HPLC) gave an additional boost to the field. Today, there are over 60 types of rugged, wellcharacterised columns capable of separating enantiomers. Unfortunately, there is a great deal of trial and error involved in choosing a particular column for chiral separation.

Chiral separation plays an important role in the determination of enantiomeric excess of API. The present chapter will present some of the rationale behind the interactions between enantiomeric solutes and a particular stationary phase along with some applications pertinent to each kind of interaction.

\subsection{ENANTIOMERS, DIASTEREOMERS, RACEMATES}

Chirality is due to the fact that the stereogenic centre, also called the chiral centre, has four different substitutions. These molecules are called asymmetrical. When a chiral compound is synthesised in an achiral environment, the compound is generated as a 50:50 equimolar mixture of the two enantiomers and is called a racemic mixture. This is because, in an achiral environment, enantiomers are energetically degenerate and interact in an identical way with the environment. Enantiomers can be differentiated from each other only in a chiral environment. Such conditions are provided during chromatographic enantiomeric separation offered by the asymmetric environment of the chiral column [6].

There are two approaches for achieving enantiomeric separation. The first approach involves a chiral mobile phase along with an achiral stationary phase, when a chiral additive is dissolved in the mobile phase and is constantly pumped through an achiral stationary phase. The second approach consists of chiral stationary phases where a chiral compound is immobilised to a solid matrix (i.e. silica gel, polymers, etc.). The separation of enantiomers using either chiral stationary or mobile phases involves the formation of transient diastereomeric complexes between the enantiomeric analytes and the chiral moiety present in the chromatographic column.

Diastereomers are chiral molecules containing two or more chiral centres with the same chemical composition and connectivity. They differ in stereochemistry about one or more chiral centres. If two stereoisomers are not enantiomers of one another, they can in principle be separated in an achiral environment i.e. using a non-chiral stationary phase [6]. 


\subsection{REQUIREMENTS FOR CHIRAL SEPARATION}

The chirality of the selector (chiral stationary phase) or the selectand (enantiomeric analytes) can arise from an asymmetric carbon, molecular asymmetry or the helicity of a polymer. Also, the bonds between substituents of the selectand and the selector can involve a single bond, but could also involve multiple bonds or surfaces. Such bonds represent the leading interactions between the selectand and selector. In chromatographic chiral separation, they control the retention on a certain column. Only when the leading interactions take place and the asymmetric moiety of the two bodies are brought in close proximity do the secondary interactions (e.g. van der Waals, steric hindrance, dipole-dipole) become effectively involved. Secondary interactions can affect the conformation and the formation energy of diastereomeric associates [7].

The interaction energy of one enantiomer in the active chiral phase can be described as the contribution of the interaction energies of all possible forms of chiral phase/solute associates. These associates are in equilibrium with fast interconversion rates. Each form contributes to the total free energy according to its particular formation energy and its particular molar fraction $[7,8]$. These complexes between the selector and selectand should also be as mutually exclusive as possible, to prevent a given interaction from occurring at multiple sites in the diastereomeric complex [6].

\subsection{THE TYPES OF MOLECULAR INTERACTIONS}

Chiral separations generally rely on the formation of transient diastereomeric complexes with differing stabilities. Complexes are defined as two or more compounds bound to one another in a definite structural relationship by forces such as hydrogen bonding, ion pairing, metal ion-to-ligand attraction, $\pi$-acid $/ \pi$ base interactions, van der Waals attraction and entropic component of desolvation. In the following sections, the most important types of molecular interactions in chiral separation are discussed.

\subsubsection{Chiral separation through hydrogen bonding}

Hydrogen bonding is a donor-acceptor interaction specifically involving hydrogen atoms [9]. When a covalently bonded hydrogen atom forms a second bond to another atom, the second bond is referred to as a hydrogen bond.

A hydrogen bond is formed by the interaction between the partners $\mathrm{R}-\mathrm{X}-\mathrm{H}$ and :Y-R' according to:

$$
\mathrm{R}-\mathrm{X}-\mathrm{H}+\mathrm{:Y}-\mathrm{R}^{\prime} \rightleftarrows \mathrm{R}-\mathrm{X}-\mathrm{H}-\cdots \cdot \mathrm{Y}^{\prime}-\mathrm{R}^{\prime}
$$

where $\mathrm{R}-\mathrm{X}-\mathrm{H}$ is the proton donor and :Y-R' makes an electron pair available for the bridging bond. The strength of hydrogen bonds depends on the solvent 
conditions in which the complex occurs. For instance, in the presence of an ionic medium (which generates an electrical field), the H-bonds of the solvate become polarised and, consequently, their symmetry can change from a symmetrical to an asymmetrical H-bond. The change in symmetry leads to weakening of the $\mathrm{H}$ bonds between solvate molecules [10].

Amide groups and peptide bonds are the most important functional groups involved in designing chiral phases that involve hydrogen bonding. Two configurations of the planar peptide bond are possible; they can be in either in a trans or cis configuration, which are in equilibrium (Figure 6.1). The trans form is energetically favoured, due to less repulsion between non-bonded atoms [11].

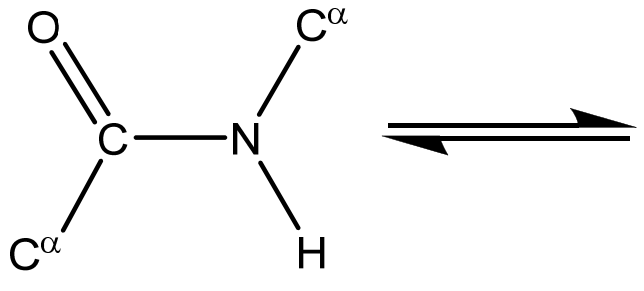

trans

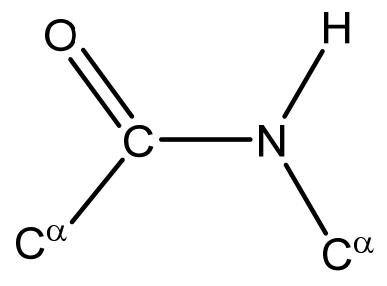

cis

Figure 6.1. Configurational equilibrium of amide group

The amide group is also an integral functional group of the backbone of proteins and determines the secondary structure of $\alpha$-helix and $\beta$-sheet. Preservation of the energy balance in the system necessitates that the backbone polypeptide groups form hydrogen bonded interactions between themselves in the protein folded state. Such requirement has important consequences for protein folding because the peptide carbonyl oxygen and $\mathrm{N}-\mathrm{H}$ groups are regularly arranged along the polypeptide backbone. Extended arrangements having optimum hydrogen-bonded interactions among residues either within or between polypeptide chains reflect the periodic regularity and result in the formation of protein secondary structures [12]. In $\alpha$-helix, the polypeptide backbone follows a path of a rigid right handed helical spring to form an arrangement in which each carbonyl group forms a hydrogen bond with the amide NH group.

$\beta$-sheets are formed when two or more almost fully extended polypeptide chains are brought together side by side, so that regular hydrogen bonds can form between the peptide amide $\mathrm{NH}$ and carbonyl oxygen groups of the adjacent chains. $\beta$-sheets can occur in two different arrangements: parallel $\beta$-sheet and antiparallel $\beta$-sheet (Figure 6.2).

In the parallel arrangement, the two adjacent polypeptide chains can close through hydrogen bonds a $\mathrm{C} 5: \mathrm{C} 7$ ring while in the antiparallel they can close both C5:C5 and a $\mathrm{C} 7: \mathrm{C} 7$ ring (vide infra). 


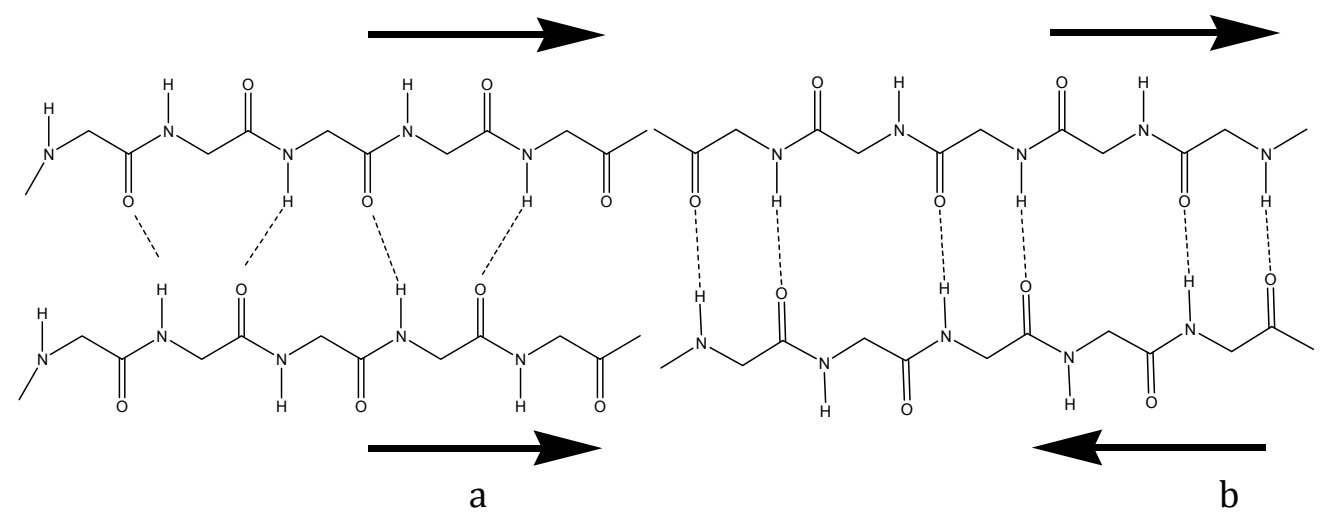

Figure 6.2. Parallel (a) and antiparallel (b) $\beta$-sheets

The first successful chiral phases used under GC conditions were N-trifluoroacetyl (TFA)-L- $\alpha$-amino acid esters. These phases separated racemates of the more volatile members of the same compounds [12]. The diamide stationary phase contained two hydrogen bonding sites, a C5 and a C7 site, where hydrogen bonding selector/selectand-associations could take place [7]:

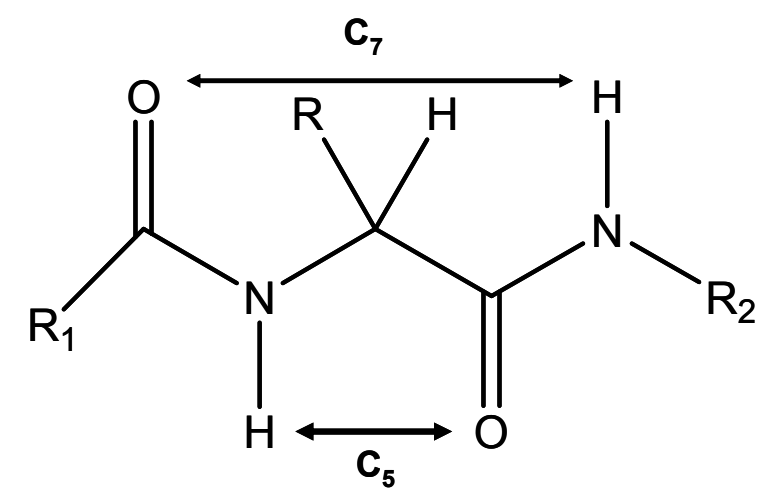

The structure of the diamide phase appeared to be similar to an anti-parallel $\beta$ sheet of poly-L-alanine. X-ray diffraction of the D,L-leucyl derivative showed the $\mathrm{C}_{5}: \mathrm{C}_{5}$ association, while the $\mathrm{C}_{7}$ site involved three molecules in the anti-parallel arrangement, closing a $\mathrm{C}_{5}: \mathrm{C}_{5}$ associate of the L-diamide selector with $\mathrm{L}$ - and $\mathrm{D}-\alpha$ amino acid derivatives [5].

Derivatised amino acids such as N-TFA- $\alpha$-amino acid esters, which can form hydrogen bonds at these sites, can be separated successfully on such types of chiral stationary phases (CSP). Such a chiral phase is known under the trade name Chirasil-Val ${ }^{\circledR}$ and is used for the separation of enantiomers by gas chromatography $[13,14]$. Table 6.1 lists some chiral compounds successfully separated on Chirasil-Val ${ }^{\circledR}$ column. 
Table 6.1. Names and structures of compounds separated on Chiralsil-Val ${ }^{\circledR}$ chiral stationary phase (CSP) consisting of embedded poly(dimethylsiloxane) with valine-tert-butylamide

\begin{tabular}{|c|c|c|c|}
\hline Name & Structure & Conditions & Ref. \\
\hline N,O-HFB-tranylcypromine & & $\mathrm{GC}-140^{\circ} \mathrm{C}$ & [18] \\
\hline 3-Dechloroethyl ifosfamide & & $\mathrm{GC}-195^{\circ} \mathrm{C}$ & [19] \\
\hline $\begin{array}{l}\text { N-Acetyl-4-chlorophenyl- } \\
\text { alanine methyl ester }\end{array}$ & & $\mathrm{GC}-160^{\circ} \mathrm{C}$ & [20] \\
\hline $\begin{array}{l}\text { Di-N,O-ethoxycarbonyl serine } \\
\text { ethyl ester }\end{array}$ & & $\mathrm{GC}-150^{\circ} \mathrm{C}$ & [21] \\
\hline $\begin{array}{l}\text { Di-N,O-PFP-allo-threonine } \\
\text { isopropyl ester }\end{array}$ & & $\begin{array}{l}\mathrm{GC} \text { - Temperature program- } \\
\text { ming: } 65^{\circ} \mathrm{C}, 4^{\circ} \mathrm{C} / \mathrm{min}, 210^{\circ} \mathrm{C} \text {. }\end{array}$ & [22] \\
\hline N-TFA-2-Aminoheptane & & $\mathrm{GC}-100^{\circ} \mathrm{C}$. & [23] \\
\hline
\end{tabular}




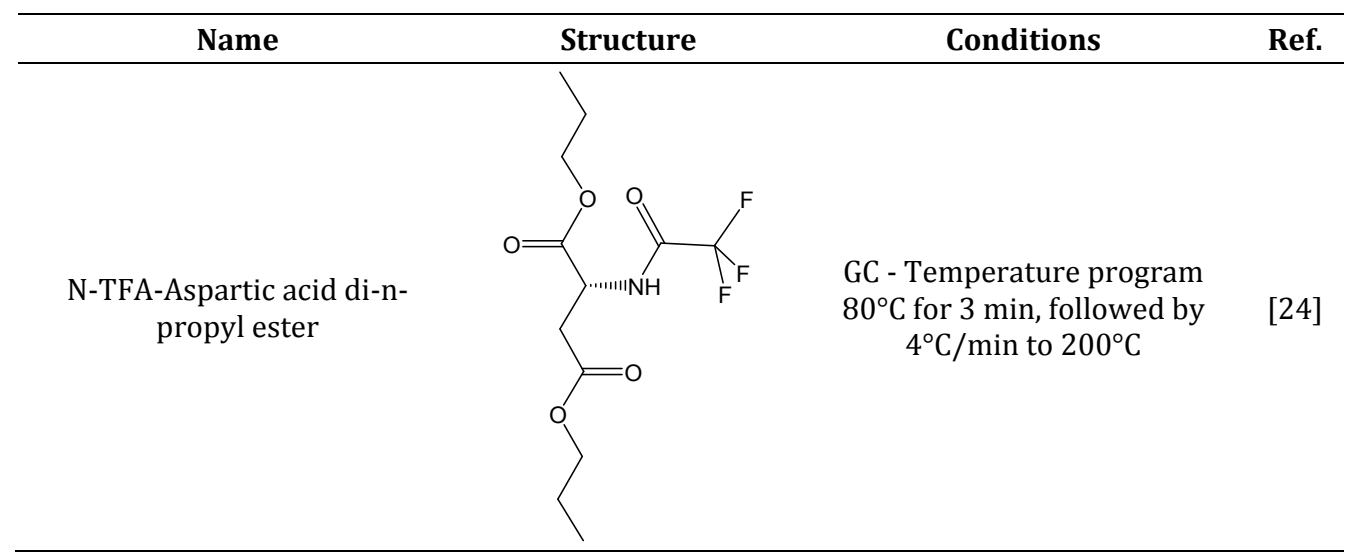

Similar interactions occur in HPLC under normal phase chromatography conditions using hexane with polar modifiers such as alcohols [15]. Another type of chiral phase based on hydrogen bonding interactions is the poly(acrylamide)type phase. Developed by Blaschke, the phase is comprised of poly(acrylamide) that incorporates phenylalanine ethyl ester. The phase has a helical structure, and the interactions are based on hydrogen bonding between the polar groups of the enantiomer and the CO-NH groups of the polymer $[16,17]$. The compounds separated on poly(acrylamide) type HPLC columns are listed in Table 6.2.

Table 6.2. The HPLC conditions and mobile phase used for the separation of listed compounds on poly(acrylamide) chiral stationary phase: Chiraspher ${ }^{\circledR}$

2-Phenyl-2,3-dihydro-
$\begin{gathered}\text { Nenzofuran-3-carboxylic acid } \\ \text { methyl ester }\end{gathered}$




\begin{tabular}{|c|c|c|c|}
\hline Name & Structure & Mobile Phase & Ref. \\
\hline $\begin{array}{c}\text { 8-Chloro-2-(2,6-difluoro- } \\
\text { benzyl)-3-methyl-1,1-dioxo- } \\
\text { 1,2,3,5-tetrahydro-1lambda*6*- } \\
\text { benzo[f][1,2,5]thiadiazepin-4- } \\
\text { one }\end{array}$ & & $\begin{array}{c}50: 50: 2 \text { hexane } / \mathrm{CHCl}_{3} / 2- \\
\text { propanol }\end{array}$ & [28] \\
\hline $\begin{array}{l}\text { 8-Chloro-3-methyl-2-(2- } \\
\text { methyl-allyl)-1,1-dioxo-1,2,3,5- } \\
\text { tetrahydro-1lambda*6*-ben- } \\
\text { zo[f] }[1,2,5] \text { thiadiazepin-4- } \\
\text { thione }\end{array}$ & & 80:20 hexane / 2-propanol & [29] \\
\hline $\begin{array}{l}\text { 5-(2-Dimethylamino-ethoxy)- } \\
\text { 3,9-dimethoxy-7H- } \\
\text { benzo[c]fluoren-7-ol }\end{array}$ & & $75: 25$ hexane / ethanol & [30] \\
\hline Bunitrolol & & $\begin{array}{c}\text { 60:20:20:0.05 hexane / } \\
\text { ethanol / methanol / } \\
\text { (25\%aq) } \mathrm{NH}_{3}\end{array}$ & [31] \\
\hline Cytoxazone & & 95:5 hexane / 2-propanol & [32] \\
\hline $\begin{array}{l}\text { 3-Methyl-3,4-dihydro-2H- } \\
\text { benzo[1,2,4]thiadiazine } 1,1- \\
\text { dioxide }\end{array}$ & & $\begin{array}{l}70: 30 \text { hexane / } \\
\text { tetrahydrofuran }\end{array}$ & [33] \\
\hline $\begin{array}{l}\text { 2,3,3a,4-Tetrahydro-1H- } \\
\text { pyrrolo[2,1-c][1,2,4]benzo- } \\
\text { thiadiazine } 5,5 \text {-dioxide }\end{array}$ & & $\begin{array}{l}70: 30 \text { hexane / } \\
\text { tetrahydrofuran }\end{array}$ & [34] \\
\hline $\begin{array}{l}\text { 3-Methyl-3,4-dihydro-2H-1,2,4- } \\
\text { benzothiadiazine 1,1-dioxide }\end{array}$ & & $\begin{array}{l}\text { 60:40 hexane / } \\
\text { tetrahydrofuran }\end{array}$ & [35] \\
\hline $\begin{array}{l}\text { 2,3,3a,4-Tetrahydro-1H- } \\
\text { pyrrolo[2,1-c][1,2,4]benzo- } \\
\text { thiadiazine } 5,5 \text {-dioxide }\end{array}$ & & $\begin{array}{l}70: 30 \text { hexane / } \\
\text { tetrahydrofuran }\end{array}$ & [35] \\
\hline
\end{tabular}


*SFC - supercritical fluid chromatography;

\subsubsection{Chiral separation through inclusion compounds}

Inclusion complexing partners are classified as hosts and guests. Complexes are structured by contacts at multiple binding sites between hosts and guests. The binding energy at a single contact site is at most a few kilocalories per mole. Contacts at several sites between hosts and guests depends on the complementary placement of the binding sites; specifically, hosts must have binding sites which cooperatively contact and attract the binding sites of guests without generating non-bonded repulsion [36]. There are two types of hosts which have been successfully employed in the chromatographic separation of enantiomers: hosts which have a hydrophobic interior and hosts with a hydrophilic interior. The hydrophilic interior means that the cavity contains heteroatoms such as oxygen, where lone pair electrons are able to participate in bonding to electron acceptors such as an organic cation (e.g., chiral crown ethers). In contrast, a host with a hydrophobic interior cavity is able to include hydrocarbon-rich parts of a molecule [37]. This type of host is found in the cyclodextrins.

\subsubsection{Cyclodextrins}

The most popular are $\alpha$-, $\beta$ - and $\gamma$-cyclodextrin $(\alpha$-CD, $\beta$-CD and $\gamma$-CD, respectively) with six, seven and eight glucose rings respectively, also called cyclohexa-, cyclohepta- and cyclooctaamylose (or CA6, CA7 and CA8). Structures, such as CA6, CA7 and CA8 have a doughnut shape and are able to host small molecules inside the cavity. Similar to amylose, the glucose units in the CAs are linked by $\alpha(1 \rightarrow 4)$ bonds that adopt a ${ }^{4} \mathrm{C}_{1}$ chair conformation (Figure 6.3). They may be considered as rigid building blocks giving fairly limited conformational freedom of the macrocycle in rotation of the C6-06 groups and limited rotational movements about the glycosidic link C1(n)-04(n-1)-C4(n-1). All glucose groups are aligned in cis configuration with the secondary 02 and 03 hydroxyls on one side and the primary 06 hydroxyls on the other side. They have the overall shape of a hollow, truncated cone with the wide side occupied by 02 and 03 and the narrow side by 06 [38].

Empirical rules for successful chiral recognition candidates using cyclodextrin selectors have evolved based on extensive chromatographic data. For instance, in the guest molecule, the presence of at least one aromatic ring enhances chiral recognition with $\beta-\mathrm{CD}$, although two rings appear to be more beneficial, particularly if the chiral centre is positioned between the two rings or between a single aromatic ring and a carbonyl [39]. The enhanced chiral recognition is attributed to increased molecular rigidity [40].

The chromatographic separation of enantiomers using CDs is usually performed using aqueous-organic mobile phases. The apparent $\mathrm{pH}$ of these mobile phases must be carefully controlled in order to handle the charge of the enantiomeric analytes. For example, separation of basic enantiomeric analytes [41] cannot be achieved at a $\mathrm{pH}$ lower than 5 . This is a consequence of the protonation of 
nitrogens in the analyte molecules. At higher $\mathrm{pH}$, complete separation can be achieved, indicating that enantiomeric separation requires the nitrogens to be partially deprotonated. Simultaneously, the hydrogen bonding between the -CD and the analytes occurs through $\mathrm{O}-\mathrm{H}$ to $\mathrm{N}$.
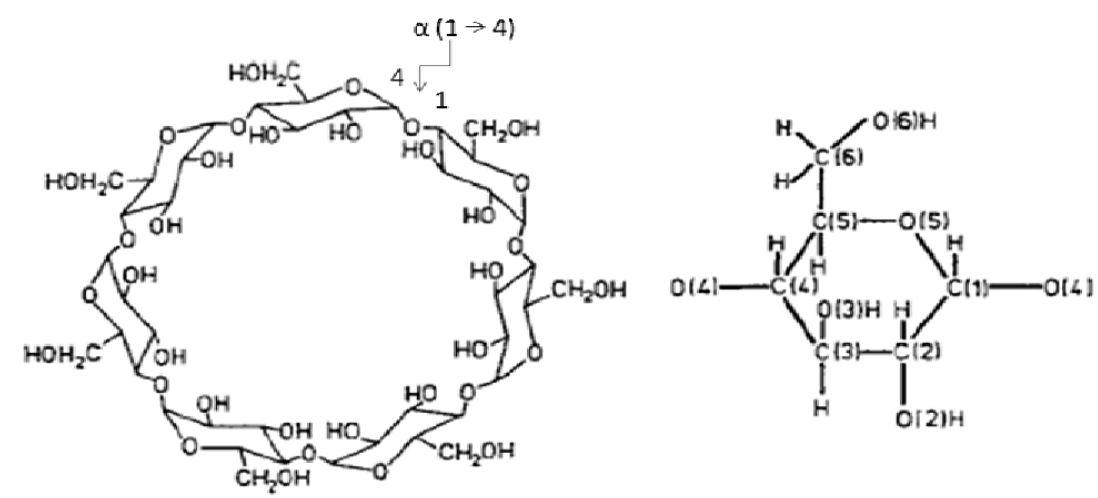

Figure 6.3. Chemical structure of CA7 ( $\beta$-CD) where the numbering of glucose unit (1-7) is performed counterclockwise (left). Atom numbering scheme for a glucose unit (right) (Adapted from [38])

The concentration of an organic modifier in a hydroorganic mobile phase also influences retention. For instance, the retention of analytes decreases as the amount of acetonitrile in the hydroorganic mobile phase increases up to a point, after which the retention starts increasing again. Such behaviour may indicate a change in retention interactions with an increased amount of acetonitrile in the mobile phase. No reversal of elution order was observed, indicating that no change in the enantioselective interactions occurred [41].

Polar organic mobile phases, such as mixtures of methanol and acetonitrile with small amounts of acetic acid, as well as triethylamine, can also be effective for the separation of enantiomers mediated by CDs. Under these conditions, the interior of the CD cavity is occupied by acetonitrile. The overwhelming concentration of acetonitrile renders its displacement by enantiomeric analytes basically impossible. Acetonitrile is a polar aprotic solvent, with limited capacity for hydrogen bond formation. As a consequence, analytes are thought to undergo hydrogen bonding under these conditions, with the secondary hydroxyl groups located at the rim of the CDs. The addition of methanol and traces of acetic acid and triethylamine allow solute retention to be modulated through solvent mediation of the hydrogen bond strength [42].

Derivatised CDs have also been used successfully in HPLC. Armstrong et al. $[43,44]$ synthesised several derivatised $\beta$-CDs and used them as chiral stationary phases under normal phase conditions. Under these conditions, inclusion is unlikely. A number of substituted derivatives were prepared including acetic anhydride, $(R)$ and $(S)$-1-(1-naphthyl)ethyl isocyanate, 2,6-dimethylphenyl iso- 
cyanate and $p$-toluoyl chloride. The presence of aromatic substitution provides possibilities for $\pi-\pi$ interaction with the aromatic substituents of the enantiomeric analytes $[43,44]$. For example, in $(R)-(-)-$ or $(S)-(+)-1-(1-$ naphthyl)ethyl carbamate of $\beta$-CD, the naphthyl ethyl moiety has some $\pi$ donor character. Incorporation of 3,5-dinitro phenyl substituents on chiral analytes promotes the formation of a $\pi-\pi$ complex. At the same time, the carbamate functionality which links the aromatic group to the $\beta$-CD produces sites which are able to undergo hydrogen bonding as well as dipole stacking with the enantiomeric analytes.

Table 6.3 gives HPLC conditions for the enantiometric separation of selected substances using cyclodextrins CSP.

\subsubsection{Crown ethers}

Crown ethers can be described as heteroatomic macrocycles with repeating units of $\left(-\mathrm{X}_{-} \mathrm{C}_{2} \mathrm{H}_{4}-\right)$ where the heteroatom $\mathrm{X}$ is usually oxygen, but may also be sulphur or nitrogen. They can also incorporate aromatic moieties which enhance their lipophilicity. Each oxygen atom possesses two unshared electron pairs. All six oxygens of the cyclic ether are turned inward to provide dipole-to-ion attractive interactions between the host and guest. The main source of interaction is iondipole attraction between ${ }^{+} \mathrm{NH} \cdots \mathrm{O}$ and ${ }^{+} \mathrm{N} \cdots \mathrm{O}$. Three hydrogen bonds can be formed between the protonated amine hydrogens and the crown ether oxygens. The ethylene units of the crown ether are turned outward and form a lipophilic barrier around the hydrogens of the hydrophilic protonated amine ion. While the host molecule is roughly planar, and the nitrogen of the guest is situated slightly out of the plane at the apex of a shallow tripod, it may be argued that the association between the crown ether and the amonium is not really an inclusion complex. The alkyl group attached to the nitrogen extends along the axis perpendicular to the plane of the cyclic ether. The protonated amine can complex at either of the two faces of the cyclic polyether. The counterion, $\mathrm{X}$; in a non-polar environment, ion pairs with positive nitrogen atom from the face opposite that occupied by the protonated ammine [45]. Cram used this principle to design chiral crown ethers. To achieve enantiomeric separation, Cram introduced additional units such as naphthalene rings into the crown ether structure, which provided additional interactions capable of discriminating between enantiomers. The host containing two chiral elements provided the highest chiral selectivity [46]. Shimbo et al. used a chiral 18-crown-6 dynamically coated on a reversed phase stationary phase $[47,48]$. This crown ether is commercially available under the trade name Crownpak ${ }^{\circledR}$. This crown ether is able to resolve a large number of enantiomeric amines, amino alcohols and amino acids using reversed phase conditions.

It was found that additives such as perchlorate ion play an important role in chiral separation. In a series of anions such as $\mathrm{ClO}_{4}^{-}, \mathrm{CF}_{3} \mathrm{COO}-\mathrm{NO}_{3}^{-}$and $\mathrm{H}_{2} \mathrm{PO}_{4}^{-}$, the retention factor of amino alcohols such as cis and trans amino indanol (at a constant $\mathrm{pH}$ of 2 ) increases in the order $\mathrm{ClO}_{4}^{-}>\mathrm{CF}_{3} \mathrm{COO}^{-}>\mathrm{NO}_{3}^{-}>\mathrm{H}_{2} \mathrm{PO}_{4}^{-}$. The selectivity factor, however, is not influenced by the nature of the anion [49]. For 
more hydrophobic analytes, retention can be modulated by the addition of organic modifiers such as methanol in the mobile phase. However, there is not a linear relationship between the amount of the organic modifier in the mobile phase and the retention factor of the enantiomeric analytes, indicating multiple types of retention interactions [50]. A different type of crown ether used to separate enantiomers is derived from 18-crown-6 tetracarboxylic acid, covalently immobilised on silica gel via the reaction between 18-crown-6 tetracarboxylic acid and amino propyl silica gel [51,52]. NMR spectroscopy of the complex between the 18-crown-6 tetracarboxylic acid and phenylglycine or phenylglycine methyl ester showed for the chiral recognition of the more stable complex the following interactions: 1 ) three $-\mathrm{NH} \cdots \mathrm{O}$ hydrogen bonds in a tripod arrangement between the polyether oxygens of 18-crown-6-tetra carboxylic acid and the ammonium moiety of the enantiomer; 2 ) a hydrophobic interaction between the polyether ring of 18-crown-6-crown ether and the phenyl ring of the enantiomer; 3 ) hydrogen bonding between the carboxylic acid of the crown ether and the carbonyl oxygen of the enantiomer [53]; 4) if the analyte contains an aromatic moiety, in some instances $\mathrm{CH}-\pi$ interactions are possible from the carbon adjacent to the carboxyl group and the aromatic moiety.

Table 6.4 gives the HPLC mobile phase composition for the enantiomeric separation of selected compounds on the CSP containing (+/-)-18-crown- 6 ether.

Table 6.3. Compositions of mobile and stationary phases for cyclodextrins-based HPLC enantiomeric separations of selected substances

\begin{tabular}{|c|c|c|c|}
\hline Name/Structure & Stationary phase & Mobile Phase & Ref. \\
\hline Isoproterenol & $\begin{array}{l}\text { Perphenylcarbamate- } \beta \text { - } \\
\text { cyclodextrin covalently } \\
\text { bonded to aminopropyl } \\
\text { silica gel (Kieselgel 100) via } \\
\text { a mono-6-urea linkage } \\
\text { (Staudinger reaction) }\end{array}$ & $\begin{array}{l}80: 201 \% \text { triethyl- } \\
\text { ammonium acetate } \\
(\mathrm{pH} 4.65) / \mathrm{CH}_{3} \mathrm{CN}\end{array}$ & [54] \\
\hline $\mathrm{OH}$ & & & \\
\hline
\end{tabular}




Stationary phase
$\begin{gathered}\text { Amino- } \beta \text {-cyclodextrin } \\ \text { bonded to silica (unknown } \\ \text { spacer) }\end{gathered}$ $\begin{gathered}20: 80 \text { methanol / aqueous } \\ 1 \% \text { triethylammonium } \\ \text { acetate buffer pH 7.0 }\end{gathered}$

2-(1H-Indol-3-yl)-succinic

acid<smiles>O=C(O)C[C@H](C(=O)O)c1c[nH]c2ccccc12</smiles>

$\beta$-cyclodextrin $(S)$ and $(R, S)$ -

hydroxypropyl derivative $\quad 40: 60: 2$ methanol / $\mathrm{H}_{2} \mathrm{O}$ / bonded to silica acetic acid

(Cyclobond RSP)<smiles>O=C1Nc2ccc(Cl)cc2C(c2ccccc2)=N[C@@H]1O</smiles>

$\beta$-cyclodextrin $(S)$ and $(R, S)$ hydroxypropyl derivative bonded to silica

(Beta-RSP-2000)
19:8:73 $\mathrm{CH}_{3} \mathrm{CN} / 1 \%$

triethylamine acetate buffer

(pH 4.5) / $\mathrm{H}_{2} \mathrm{O}$ 


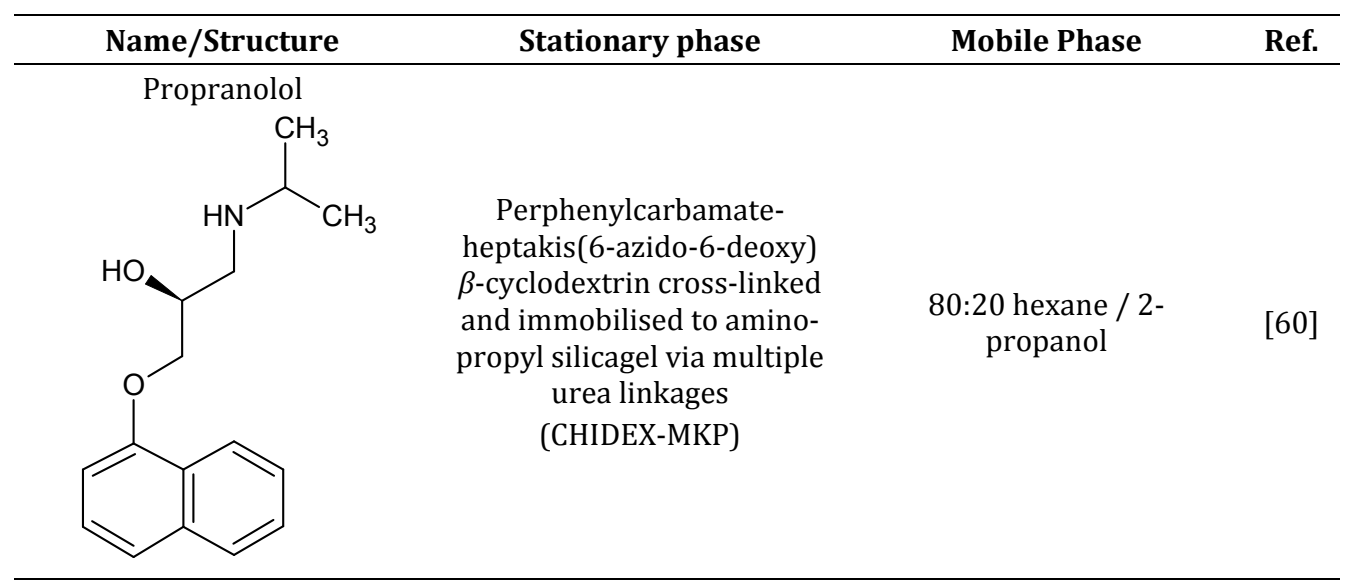

(2-Nonyloxy-phenyl)carbamic acid 1-methyl-2piperidin-1-yl-ethyl ester

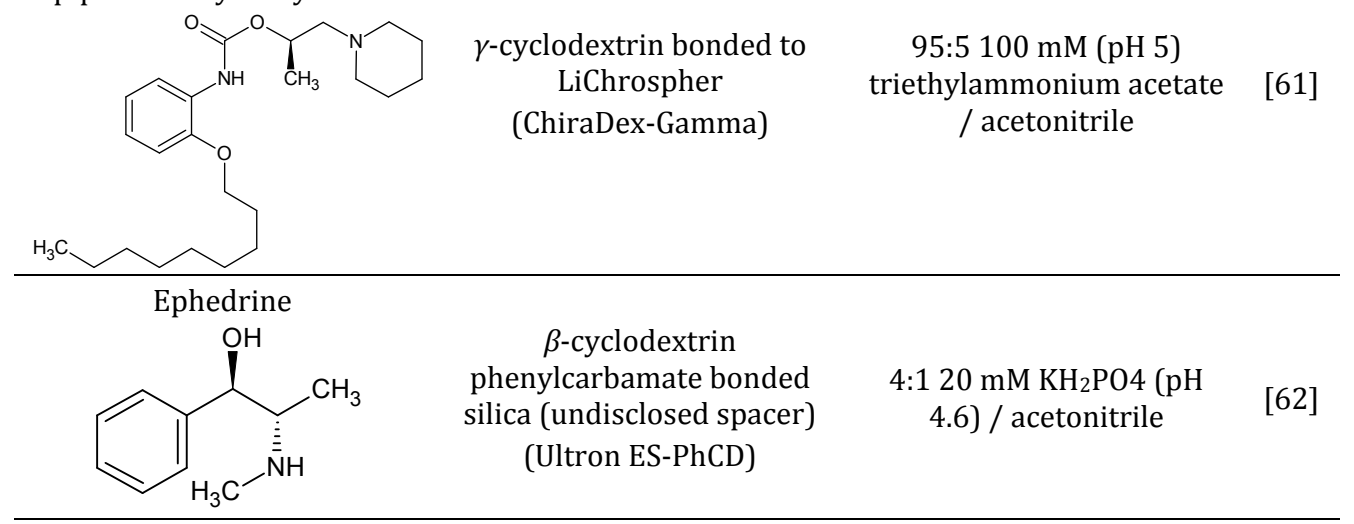

$\mathrm{N}$-[2-(7-Fluoro-1,2,3,4-

tetrahydro-naphthalen-1-

yl)-ethyl]-acetamide<smiles>CC(=O)NCC[C@@H]1CCCc2ccc(F)cc21</smiles>

$\beta$-cyclodextrin covalently bonded to glycidoxypropyl silica

methanol

(Cyclobond I 2000) 


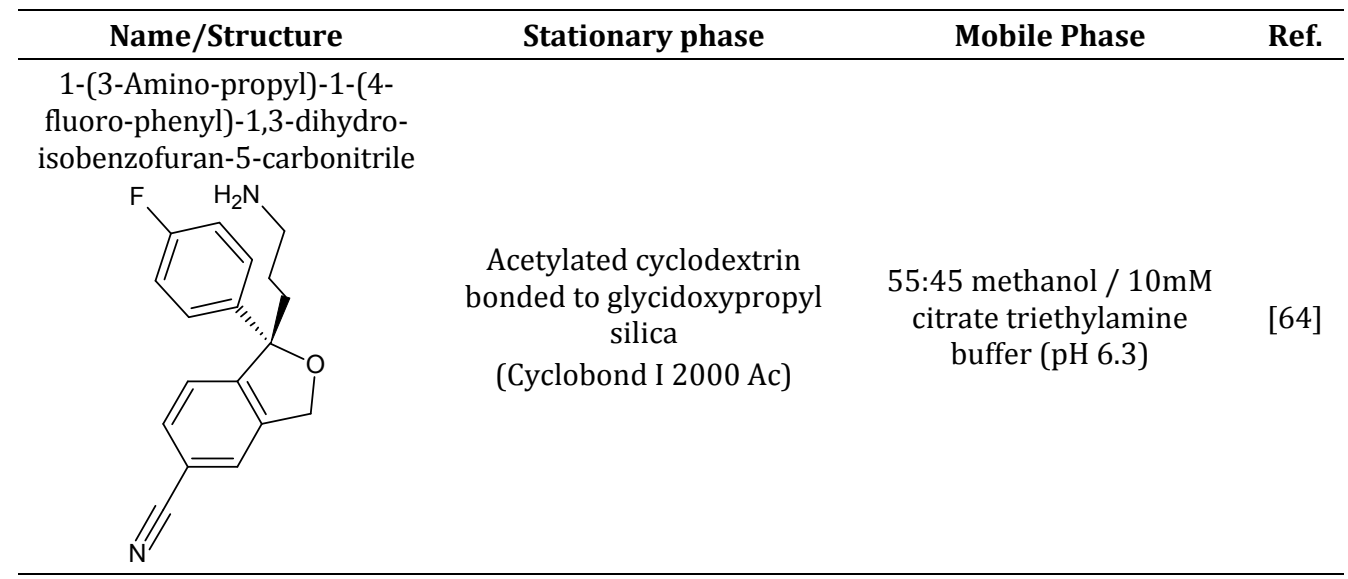

Acetoxy-phenyl-acetic acid

2,2,2-trifluoro-ethyl ester<smiles>CC(=O)O[C@H](C(=O)OCC(F)(F)F)c1ccccc1</smiles>

Permethylated- $\beta$ cyclodextrin covalently bonded to silicagel undisclosed spacer

(Sumichiral 0A 7500)

3-Hydroxy-1-[4-(7-nitrobenzo[1,2,5]oxadiazol-4-yl)piperazin-1-yl]-butan-1-one<smiles>C[C@H](O)CC(=O)N1CCN(c2ccc([N+](=O)[O-])c3nonc23)CC1</smiles>

$\beta$-cyclodextrin phenylcarbamate bonded silica (undisclosed spacer) (Ultron ES-PhCD)

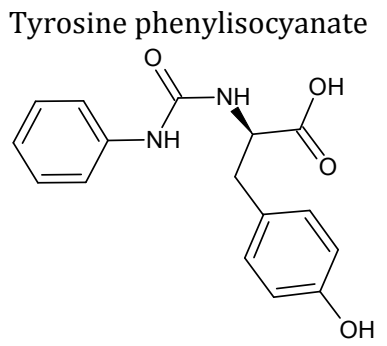

$\beta$-cyclodextrin covalently bonded to glycidoxypropyl silica (Cyclobond I)
490:10:1:3 acetonitrile / methanol / acetic acid / triethylammine 


\begin{tabular}{|c|c|c|c|}
\hline Name/Structure & Stationary phase & Mobile Phase & Ref. \\
\hline 4-Bromo-phenylethanol & $\begin{array}{l}\text { Perphenylcarbamate-hepta- } \\
\text { kis(6-azido-6-deoxy) } \beta \text { - } \\
\text { cyclodextrin cross-linked } \\
\text { and immobilised to } \\
\text { aminopropyl silicagel via } \\
\text { multiple urea linkages } \\
\text { (CHIDEX-MKP) }\end{array}$ & 2-propanol & [68] \\
\hline $\begin{array}{l}\text { Methadone } \\
\mathrm{CH}_{3}\end{array}$ & $\begin{array}{c}\beta \text {-cyclodextrin }(S) \text { and }(R, S) \text { - } \\
\text { hydroxypropyl derivative } \\
\text { bonded to silica } \\
(\beta \text {-RSP-2000) }\end{array}$ & $\begin{array}{c}\text { 90:10 1\% triethylammine } \\
\text { / acetonitrile }(\mathrm{pH} 3.2 \text { with } \\
\left.\mathrm{H}_{3} \mathrm{PO}_{4}\right)\end{array}$ & [69] \\
\hline
\end{tabular}

N-(3-Chloro-benzoyl)alanylglycine<smiles>C[C@H](NC(=O)c1cccc(Cl)c1)C(=O)NCC(=O)O</smiles>

(R)-Naphthylethyl-isocyanate derivatised $\beta$-cyclodextrin bonded to silica (Cyclobond I 2000 RN)

490:10:1:2 acetonitrile / methanol / acetic acid / triethylammine

Phenylalanine phenylisocyanate<smiles>O=C(Nc1ccccc1)N[C@@H](Cc1ccccc1)C(=O)O</smiles>

$(R)$-Naphthyl-ethylisocyanate derivatised $\beta$-cyclo480:20:1:2 acetonitrile / methanol / acetic acid / dextrin bonded to silica (480:20:1:2 $\mathrm{CH}_{3} \mathrm{CN} /$ methanol $/ \mathrm{CH}_{3} \mathrm{CO}_{2} \mathrm{H} / \mathrm{Et}_{3} \mathrm{~N}$ )

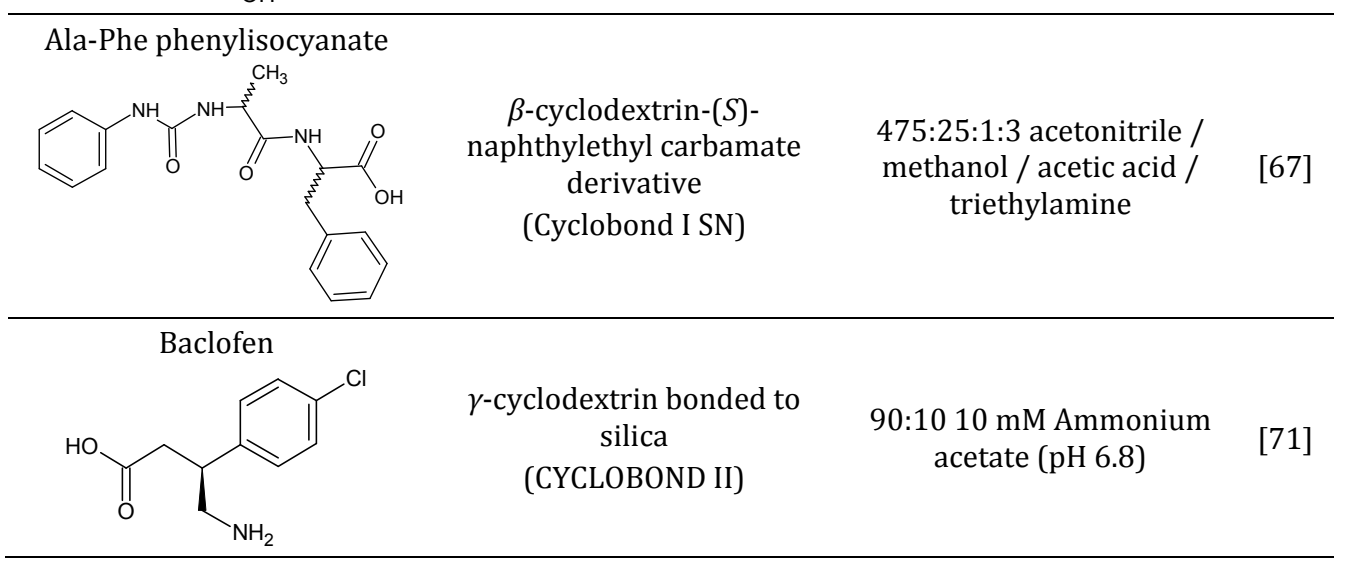




\begin{tabular}{|c|c|c|c|}
\hline Name/Structure & Stationary phase & Mobile Phase & Ref. \\
\hline $\begin{array}{c}\text { Benzoic acid 2-(6-amin } \\
\text { purin-9-ylmethoxy)-2 } \\
\text { phenyl-ethyl ester }\end{array}$ & $\begin{array}{l}\beta \text {-cyclodextrin }(S) \text { and }(R, S) \text { - } \\
\text { hydroxypropyl derivative } \\
\text { bonded to silica } \\
\text { (Cyclobond RSP) }\end{array}$ & $98: 2 \mathrm{CH}_{3} \mathrm{CN} /$ methanol & [72] \\
\hline $\begin{array}{c}\text { 3-Methoxy-6a,11a-dihyd } \\
\text { 6H-benzo[4,5]furo[3,2 } \\
\text { c]chromene }\end{array}$ & $\begin{array}{l}\alpha \text {-cyclodextrin bonded to } \\
\text { silica } \\
\text { (CYCLOBOND III) }\end{array}$ & $80: 20 \mathrm{H}_{2} \mathrm{O} /$ methanol & [73] \\
\hline
\end{tabular}

Dimethyl-[4-(2-phenyl4,5,6,7-tetrahydro-benzofuran-4-yl)-phenyl]-amine<smiles>CN(C)c1ccc(C2CCCc3oc(-c4ccccc4)cc32)cc1</smiles>

$\beta$-cyclodextrin $(S)$ and $(R, S)$ hydroxypropyl derivative bonded to silica (Cyclobond RSP)

60:40:0.1:0.1 $\mathrm{CH}_{3} \mathrm{OH} /$ $\mathrm{H}_{2} \mathrm{O}$ / triethylamine / $\mathrm{CH}_{3} \mathrm{CO}_{2} \mathrm{H}(\mathrm{pH} 8)$
Heptakis-2,3-0-dimethyl $\beta$ -

Cyclodextrin covalently bonded to glycidox isopropyl silica

(Cyclobond I DM)

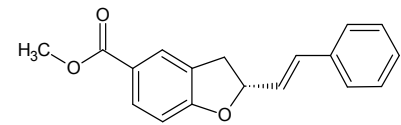

2-Ethylidene-1,5-dimethyl-

3,3-diphenyl-pyrrolidine<smiles>C/C=C1\N(C)[C@H](C)CC1(c1ccccc1)c1ccccc1</smiles>

$\beta$-cyclodextrin $(S)$ and $(R, S)$ hydroxypropyl derivative bonded to silica ( $\beta$-RSP-2000)
19:9:72 $\mathrm{CH}_{3} \mathrm{CN} / 1 \%$ triethylammonium acetate (pH 4.5) in $\mathrm{H}_{2} \mathrm{O} / \mathrm{H}_{2} \mathrm{O}$ 


\begin{tabular}{cccc}
\hline Name/Structure & Stationary phase & Mobile Phase & Ref. \\
\hline $\begin{array}{c}\text { 8-Iodo-5-methoxy-7-(4- } \\
\text { methoxy-phenyl)-5H- } \\
\text { pyrano[4,3-b]pyridine }\end{array}$ & $\begin{array}{c}\beta \text {-cyclodextrin covalently } \\
\text { bonded to glycidoxypropyl } \\
\text { silica } \\
\text { (Cyclobond I) }\end{array}$ & Not reported
\end{tabular}

4-[4-(2-Hydroxy-cyclo-

hexylmethyl)-phenoxy]-3-

methyl-but-2-enoic acid ethyl ester

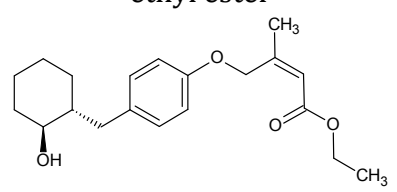

$\beta$-cyclodextrin bonded to silica

4:1 methanol / $\mathrm{H}_{2} \mathrm{O}$

(Nucleodex beta-OH)

2'-Hydroxyflavanone<smiles>O=C1CC(c2ccccc2O)Oc2ccccc21</smiles>

Perphenylcarbamate- $\beta$ cyclodextrin covalently bonded to aminopropyl silicagel (Kromasil silica) via a mono-6-urea linkage (CHIDEX-SKP)

Thioridazine<smiles>CSc1ccc2c(c1)N(CC[C@@H]1CCCCN1C)c1ccccc1S2</smiles>

$\beta$-cyclodextrin bonded to LiChrospher (ChiraDex)

50:50 Phosphate buffer $0.05 \mathrm{M}, \mathrm{pH} 6.5$ / acetonitrile
Bis(alpha-

methylbenzyl)amine

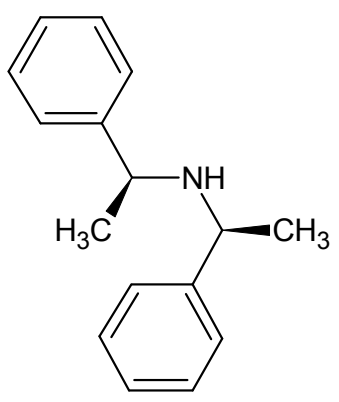

Acetylated cyclodextrin bonded to glycidoxypropyl silica

(Cyclobond I 2000 Ac)
100:0.1 $\mathrm{H}_{2} \mathrm{O}$ /

triethylammonium acetate [81]

(pH 4.1) 


Stationary phase
Mobile Phase




\begin{tabular}{llll}
\hline Name/Structure & Stationary phase & Mobile Phase & Ref. \\
\hline 2-Hydroxy-2-phenyl- & & \\
acetamide \\
$\beta$-cyclodextrin bonded to \\
$\begin{array}{c}\text { Silica } \\
\text { (Nucleodex beta-OH) }\end{array}$
\end{tabular}

6-phenyl-1,2,3,4,5,6-

hexahydro-2,6-methano-3-

benzazocin-8-ol

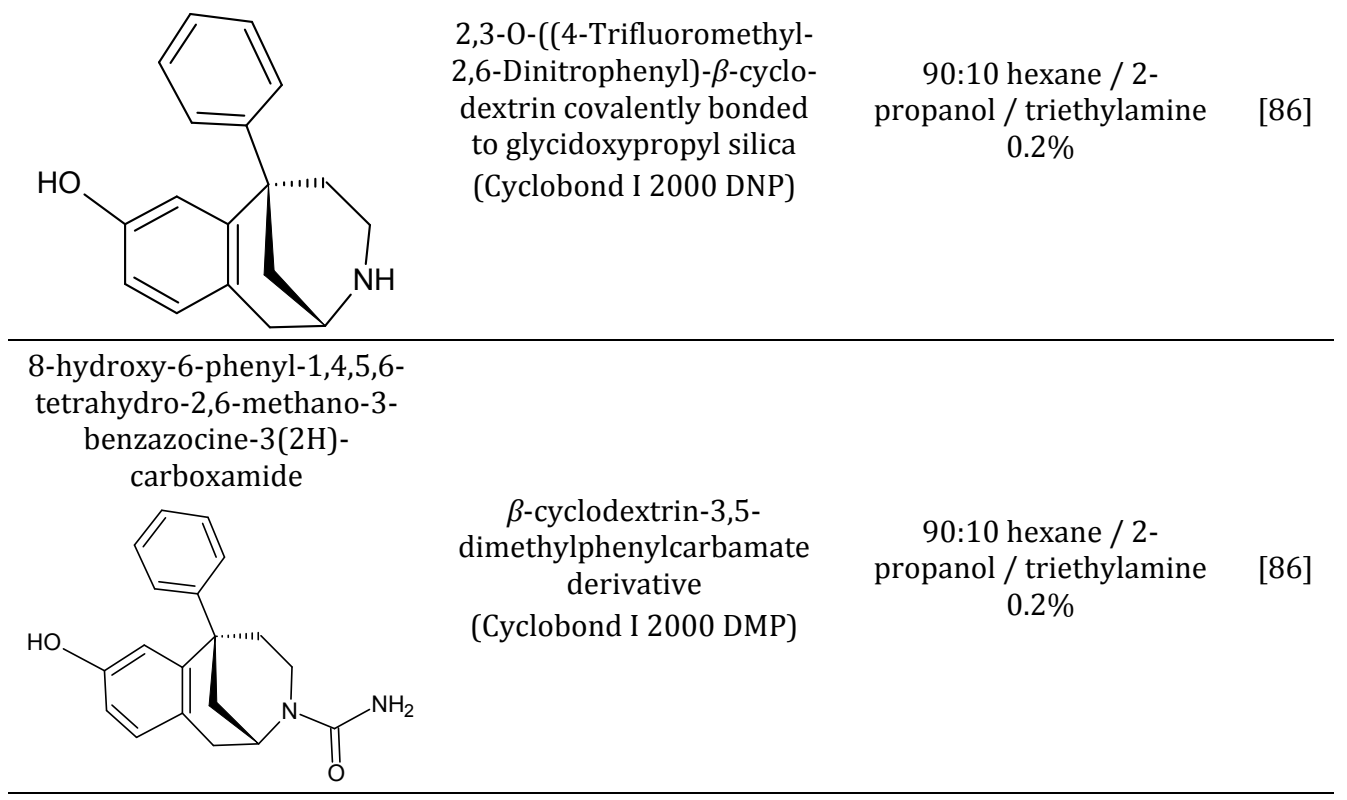

3-methyl-6-phenyl-

1,2,3,4,5,6-hexahydro-1,5-

methano-3-benzazocine

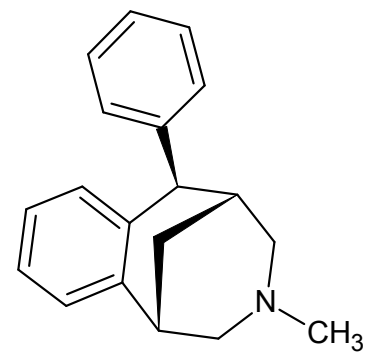

$\beta$-cyclodextrin covalently bonded to glycidoxypropyl silica

65:35 ammonium acetate buffer $\mathrm{pH} 7$ / acetonitrile

(Cyclobond I 2000) 


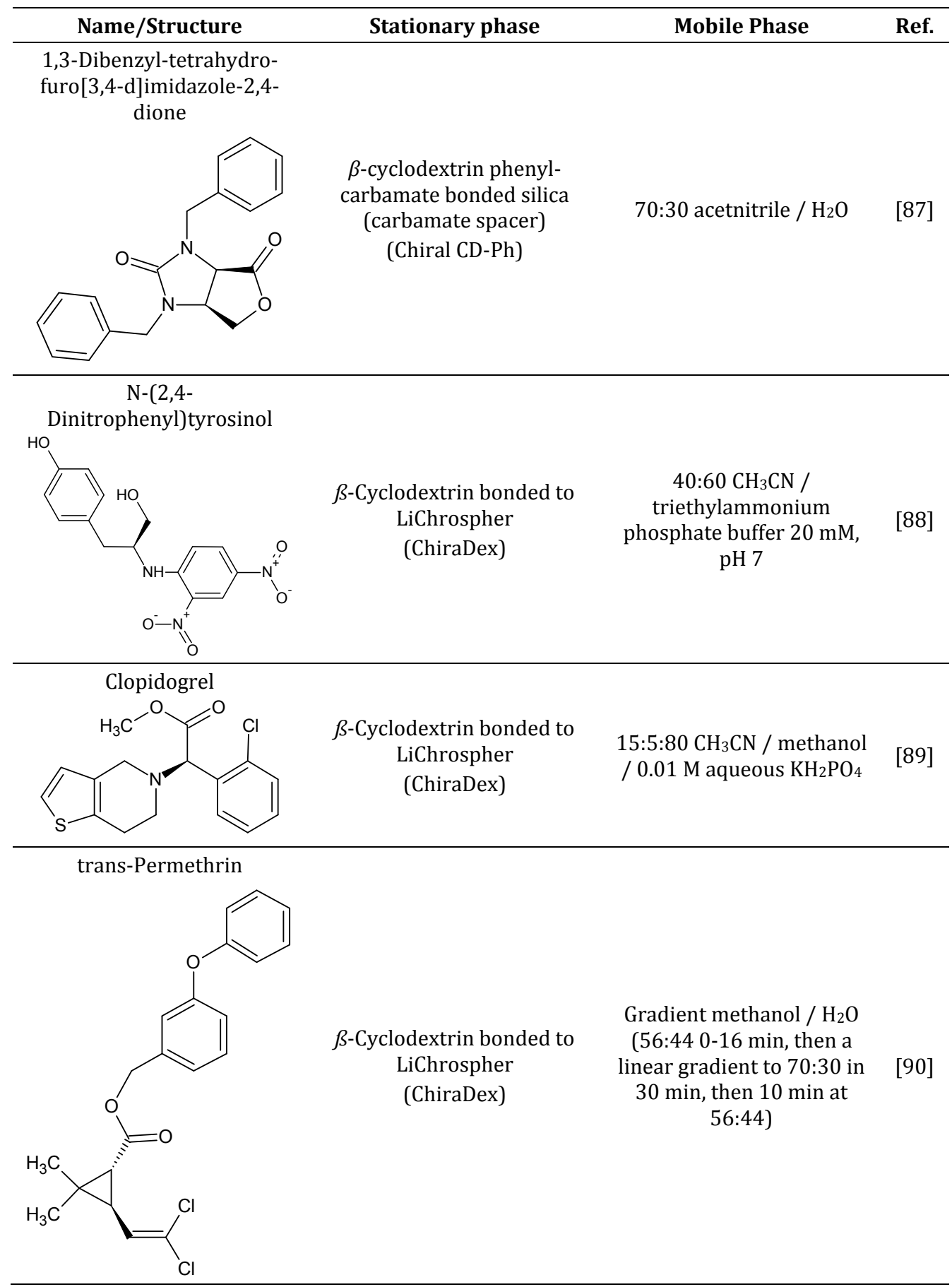


Table 6.4. Mobile phase compositions for the enantiomeric separation of selected substances on (+/-)-18-crown-6 ether coated on octadecylsilyl silica(ODS) stationary phase

\begin{tabular}{|c|c|c|c|}
\hline Name & Structure & Mobile Phase & Ref. \\
\hline $\begin{array}{c}\text { Amino-phenyl-acetic acid } \\
\text { methyl ester }\end{array}$ & & Aqueous $\mathrm{HClO}_{4}(\mathrm{pH} 2.0$ ) & [91] \\
\hline $\begin{array}{l}\text { 2-Amino-4-phenyl- } \\
\text { butyramide }\end{array}$ & & $\mathrm{HClO}_{4}$ Solution (pH 2) & [92] \\
\hline $\begin{array}{l}\text { 3-Amino-3-cyclohex-3- } \\
\text { enyl-propionic acid }\end{array}$ & & Aqueous $\mathrm{HClO}_{4}(\mathrm{pH} 2.0)$ & [93] \\
\hline Amino-phenyl-acetic acid & & Aqueous $\mathrm{HClO}_{4}(\mathrm{pH} 1.5-2.0)$ & [94] \\
\hline $\begin{array}{l}\text { 2-Amino-pentanedioic } \\
\text { acid }\end{array}$ & & Aqueous $\mathrm{HClO}_{4}(\mathrm{pH} 2.0)$ & [95] \\
\hline $\begin{array}{c}\text { 2-Amino-3-(4-hydroxy- } \\
{[1,2,5] \text { thiadiazol-3-yl)- }} \\
\text { propionic acid }\end{array}$ & & $\begin{array}{l}\text { Aqueous triflouro acetic acid } \\
\qquad(\mathrm{pH} \mathrm{2})\end{array}$ & [96] \\
\hline 2-Amino-cyclohexanol & & $\begin{array}{c}\text { 95:5:2 } \mathrm{H}_{2} \mathrm{O} / \text { methanol / } \\
\quad \mathrm{CF}_{3} \mathrm{CO}_{2} \mathrm{H}\end{array}$ & [97] \\
\hline
\end{tabular}




\begin{tabular}{|c|c|c|c|}
\hline Name & Structure & Mobile Phase & Ref. \\
\hline Alanine & & Aqueous $\mathrm{HClO}_{4}(\mathrm{pH} 1.5$ ) & [98] \\
\hline Leucine & $\mathrm{H}_{2} \mathrm{~N}$ & Aqueous $\mathrm{HClO}_{4}(\mathrm{pH} 2)$ & [99] \\
\hline $\begin{array}{l}\text { 2-Amino-butyric acid } \\
\text { methyl ester }\end{array}$ & & Aqueous $\mathrm{HClO}_{4}(\mathrm{pH}$ 1.3) & [100] \\
\hline Baclofen & & $\begin{array}{c}\text { 90:10 } 10 \mathrm{mM} \text { ammonium } \\
\text { acetate (pH 6.8) }\end{array}$ & {$[71]$} \\
\hline $\begin{array}{l}\text { 2-Amino-3-phenyl- } \\
\text { propionitrile }\end{array}$ & & $\begin{array}{c}\text { 90:10 } 10 \mathrm{mM} \mathrm{H}_{2} \mathrm{O} \mathrm{HClO}_{4} / \\
\text { methanol }\end{array}$ & [101] \\
\hline $\begin{array}{c}\text { (RR,SS)-1-(4-Hydroxy- } \\
\text { phenyl)-2-amino-1-pro- } \\
\text { panol }\end{array}$ & & Aqueous $\mathrm{HClO}_{4}(\mathrm{pH} 1.0$ ) & [102] \\
\hline $\begin{array}{c}\text { 7-Ethyl-1,2,3,4- } \\
\text { tetrahydro-1- } \\
\text { napthylamine hydro- } \\
\text { chloride }\end{array}$ & & $\begin{array}{c}90: 10 \mathrm{H}_{2} \mathrm{O}+0.1 \% \\
\text { trifluoroacetic acid / } \\
\text { methanol }\end{array}$ & [103] \\
\hline 2-Amino-propionamide & & $60 \mathrm{mM} \mathrm{HClO}_{4}$ & [104] \\
\hline Phenylglycine & & $\begin{array}{c}90: 10 \mathrm{HClO}^{\mathrm{H}} \mathrm{H}_{2} \mathrm{O}(\mathrm{pH} 1.2) \\
\text { methanol }\end{array}$ & [105] \\
\hline
\end{tabular}




\begin{tabular}{|c|c|c|c|}
\hline Name & Structure & Mobile Phase & Ref. \\
\hline $\begin{array}{l}\text { 2-Amino-3-phenyl- } \\
\text { propionic acid ethyl ester }\end{array}$ & & $\begin{array}{c}\text { 90:10 } \mathrm{HClO}_{4}(\mathrm{pH} 2) / \\
\text { methanol }\end{array}$ & [106] \\
\hline 2-Amino-succinamic acid & & $100 \mathrm{mM} \mathrm{HClO}_{4}(\mathrm{pH} \mathrm{1})$ & [107] \\
\hline $\begin{array}{l}\text { 7-Methoxy-2- } \\
\text { aminotetralin }\end{array}$ & & $\begin{array}{c}\text { 15:85 methanol / aqueous } \\
1 \% \mathrm{HClO}_{4}\end{array}$ & [108] \\
\hline $\begin{array}{l}\text { 2-Amino-3-[3-(2-fluoro- } \\
\text { ethyl)-4-methoxy- } \\
\text { phenyl]-propionic acid }\end{array}$ & & $\begin{array}{c}\text { 95:5 Aqueous } \mathrm{HClO}_{4}(\mathrm{pH} 2) / \\
\text { methanol }\end{array}$ & [109] \\
\hline$p$-Borono-phenylalanine & & $0.4 \%$ Aqueous $\mathrm{HClO}_{4}$ & [110] \\
\hline $\begin{array}{c}\text { Amino-(2-hydroxy-4-pro- } \\
\text { pyl-2H-pyrazol-3-yl)- } \\
\text { acetic acid }\end{array}$ & & $\mathrm{HClO}_{4}$ & [111] \\
\hline $\begin{array}{l}\text { 2-Amino-2-phenyl- } \\
\text { acetamide }\end{array}$ & & $\mathrm{HClO}_{4}(\mathrm{pH} 1.3)$ & [85] \\
\hline
\end{tabular}




\begin{tabular}{llll}
\hline Name & Mobile Phase & Ref. \\
\hline \\
2-Amino-cyclobutane- \\
carboxylic acid \\
2-Amino-4-[[(E)-2-carbo- \\
phoryl]butanoic acid
\end{tabular}

\subsubsection{Charge transfer}

Charge transfer complexes are an electron donor/electron acceptor associations for which an intermolecular electronic charge transfer is observed [117]. Sometimes, it is very difficult to discriminate between electronic charge transfer and donor-acceptor complexes. A donor-acceptor complex may also involve adduct formation by proton transfer. At the same time, there is no definite boundary between coordination complexes and charge transfer complexes. In charge transfer complexes, an electron may be transferred from a non-bonding orbital of the donor to an anti-bonding orbital of the acceptor. A coordination complex involves the donation of a lone pair of electrons from the donor to a vacant orbital of the acceptor molecule. In general, the acceptor is a metal atom of the transition series. The adducts are usually stabilised by other bonding contributions [118]. 
Charge transfer complexes can be classified according to the type of orbitals interacting:

1. $\pi$ donors and $\pi$ acceptors in which it is a $\pi$ orbital which donates or accepts the bonding electron, which is delocalized over the orbital of the adduct. This type of charge transfer complexes are usually strong complexes.

2. $\sigma$ donors and $\sigma$ acceptors in which the bonding involves the s orbital of the reactants.

3. $\mathrm{n}$ donors where the bonding orbital is localized within the reactant molecules. An example of this effect is of tertiary nitrogen [118].

In the following we will focus on the aromatic interactions which occur between a $\pi$ donor molecule and a $\pi$ acceptor counterpart. They provide stability to duplex DNA and are believed to contribute to the unique properties of thermophilic proteins. They may play a role in amyloid aggregation in Alzheimer's desease, being a common motif in biomolecular recognition. They are integral part in enantiomeric recognition when the stationary phase consists of a $\pi$ donor/acceptor and the analyte contains a $\pi$ donor/acceptore moiety

Aromatic interactions have been suggested to consist of van der Waals, hydrophobic and electrostatic forces. The relative contribution and magnitude of each of these components is still a matter of debate. The controversy arises from the fact that aromatic groups interact in one of several geometries, depending on the nature of the rings involved [119]. The electrostatic component has been suggested to arise from interactions of the quadrupole moments of the aromatic rings. The edge-face geometry can be considered as a $\mathrm{CH}-\pi$ interaction found in benzene in the solid and liquid state, and is commonly observed between aromatic residues in proteins [120]. Aromatic rings can also act as hydrogen bond acceptors. The presence of a solvent affects the complexation constant describing the equilibrium between the individual components of the complex. This is due to the competition of solvent molecules toward each component of the complex. The solvent does not have to be a charge-transfer competitor. Competitive interactions such as hydrogen bonds can also affect the equilibrium. When the equilibrium constant of complexation is quite low, the influence of the solvent is very significant, due to its overwhelming concentration compared to the concentration of the complex.

\subsubsection{Chiral separation through a combination of charge transfer, hydrogen bonding and electrostatic interactions}

In 1966, Pirckle first reported that $(S)$-1-phenylmethylamine caused ${ }^{19} \mathrm{~F}-\mathrm{NMR}$ non-equivalency of 2,2,2-trifluoro-1-phenylethanol in a carbon tetrachloride solution [121]. In later studies, 2,2,2-trifluoro-1-(9-anthryl)ethanol, an NMR shift reagent, was used as a mobile phase additive to separate racemates of 2,4dinitrophenyl methyl sulphoxide on a silica gel column [122]. Later, one enantiomer of this fluoroalcohol was covalently attached to silica gel and used for the resolution of a large number of solutes, including sulphoxides, lactones, 
derivatives of alcohols, amines, amino acids, hydroxy acids and mercaptans [123]. The model used to describe complex formation between the selectand and the selector consists of three simultaneous points of interaction first described by Dalgliesh $[3,124]$. The Pirkle-type phases are based on amino acids bound on one side to the silica gel matrix and on the other side derivatised with an aromatic moiety which can be either a $\pi$ donor or a $\pi$ acceptor. This chiral stationary phase (CSP) undergoes $\pi-\pi$ interactions with enantiomeric analytes which have an aromatic moiety. The complex is stabilised through additional interactions such as hydrogen bonding, dipole-dipole interactions or steric repulsion [125]. An improved chiral stationary phase synthesised by Pirkle's group possesses both dinitrobenzoyl and naphtyl moieties, allowing for simultaneous face-to-face $\pi-\pi$ interactions and phase-to-edge interactions [126]. The elution order is controlled through the configuration of the CSP. These phases were used under normal phase conditions, with mixtures of solvents such as hexane-isopropyl alcohol. They were also used under supercritical and reversed phase conditions [125]. Table 6.5 lists some enantiomeric compounds and the compositions of CSP and mobile phase for the separation of their racemic mixture based on simultaneous charge transfer and hydrogen bonding interactions.

Another type of CSP capable of undergoing charge transfer interactions is the one developed by Lindner's group [127], based on cinchona alkaloids. They can operate under both normal phase and reversed phase. Under reversed phase conditions, they operate through an ion pairing interaction with acidic enantiomeric analytes. Under normal phase conditions, they operate through $\pi-\pi$ interactions as well as ion pairing $[128,129]$.

The basis of the interactions in the complex consists of electrostatic interactions between the quinuclidin of the amine ion and the carboxylate of the selectand, the $\pi-\pi$ interactions between the quinoline ring of the selector and the dinitrobenzoyl of the selectand and the steric repulsion between the leucine side chain and the carbamate moiety [129]. Table 6.6 lists some successful separation on the commercial Chiral $\mathrm{AX}^{\circledR}$ column based on quinine CSP.

Table 6.5. Selected compounds and the conditions for the separation of their racemic mixture on CSP working through charge transfer and H-bonding

\begin{tabular}{cccc}
\hline Name/Structure & Stationary phase & Mobile Phase & Ref. \\
\hline 3-tert-Butyl-3H-naphtho[1,2- \\
c]furan-1-one
\end{tabular}




Stationary phase
3-Methyl-2-phenyl-2,3-dihydro-
benzofuran $\begin{gathered}\text { Mobile Phase } \\ \begin{array}{c}\text { (3R,4S)-4-(3,5-Dinitrobenz- } \\ \text { amido)-3-[3-(dimethylsily- } \\ \text { loxy)propyl]-1,2,3,4- } \\ \text { tetrahydrophenanthrene } \\ ((\mathrm{S}, \mathrm{S}) \text {-Whelk-01) }\end{array}\end{gathered}$

4-Bromo-benzoic acid 1-(6-oxo-

cyclohex-1-enyl)-hept-4-enyl

ester<smiles>CC/C=C\CC[C@H](OC(=O)c1ccc(Br)cc1)C1=CCCCC1=O</smiles>

$(3 S, 4 R)-4-(3,5-$ Dinitro-

benzamido)-3-[3-(dimethylsilyloxy)propyl]-1,2,3,4tetrahydrophenanthrene

95:5 hexane / 2propanol

4-Cyano-3-(4-fluoro-phenyl)butyric acid methyl ester

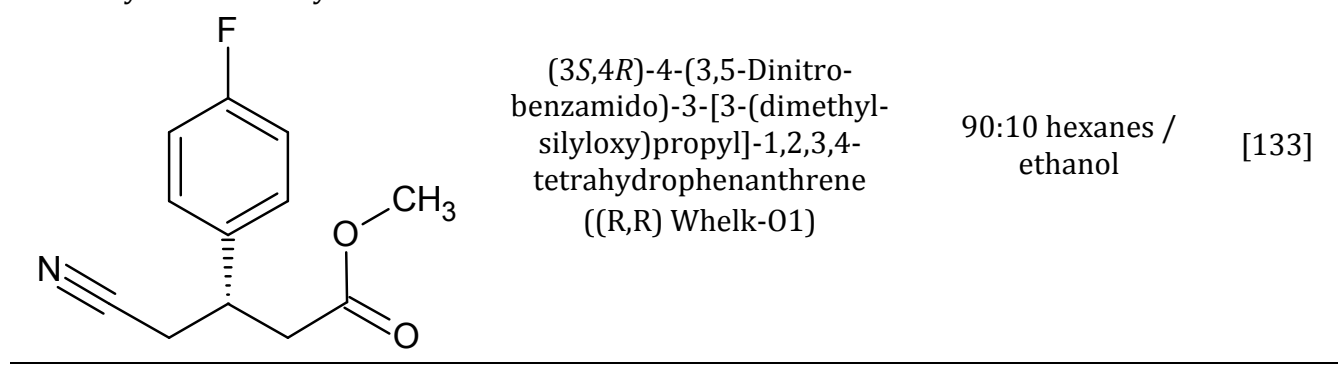




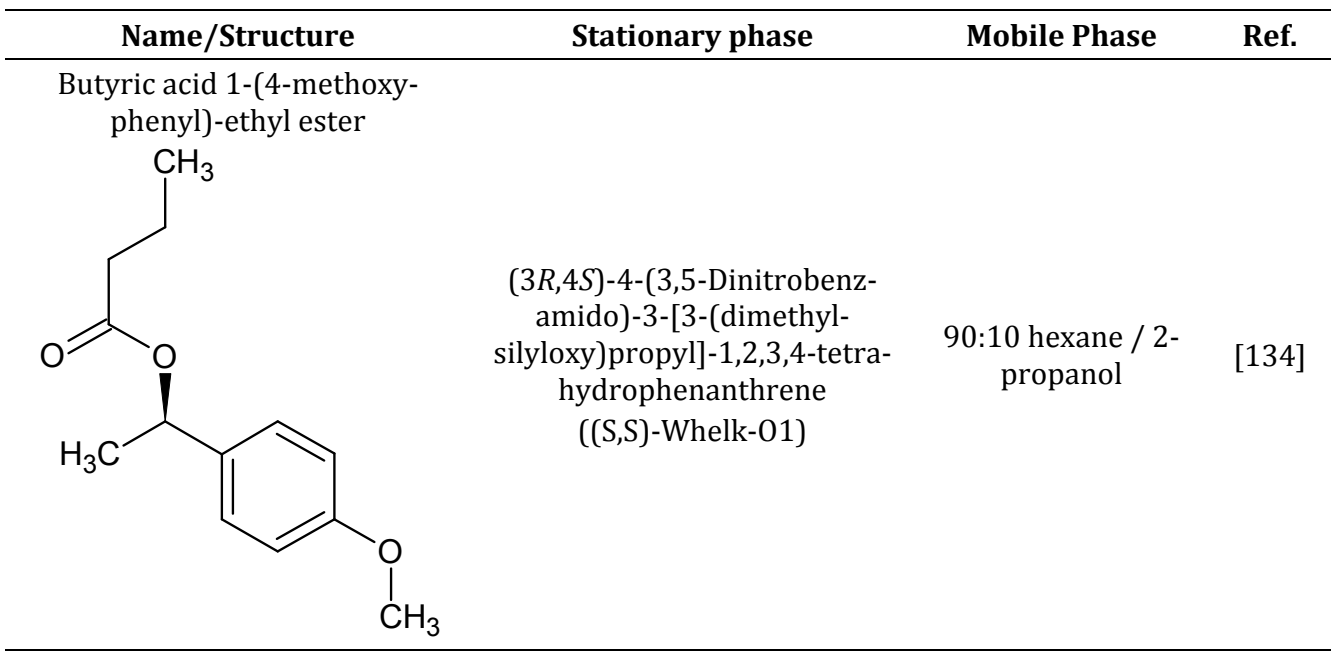

$((E)$-1-Hydroxy-5-methyl-hex2-enyl)-phosphonic acid dimethyl ester<smiles>COP(=O)(OC)[C@H](O)/C=C/CC(C)C</smiles>

(3R,4S)-4-(3,5-Dinitro-

benzamido)-3-[3-(dimethylsilyloxy)propyl]-1,2,3,4tetrahydrophenanthrene

80:20 hexane / ethanol

((S,S)-Whelk-01)

$$
(3 S, 4 R)-4-(3,5-
$$

Dinitrobenzamido)-3-[3(trioxysilyl)propyl]-1,2,3,4tetrahydrophenanthrene $((R, R)$ Whelk-02)
700:300:2:1 methanol / $\mathrm{H}_{2} \mathrm{O} /$ acetic acid / triethylamine<smiles>CCCN(CCC)C(=O)[C@H](N)Cc1ccc(OCCN(CC)CC)cc1</smiles>

N-[2-Methoxymethoxy-1-(2methoxy-5-methyl-phenyl)ethyl]-acetamide<smiles>COCOC[C@H](NC(C)=O)c1cc(C)ccc1OC</smiles>

4-(3,5-Dinitrobenzamido)-3tetrahydrophenanthrene derivative incorporated into polymethylhydrosiloxane (coated on silicagel 300A)

30:20 hexanes / 2propanol 


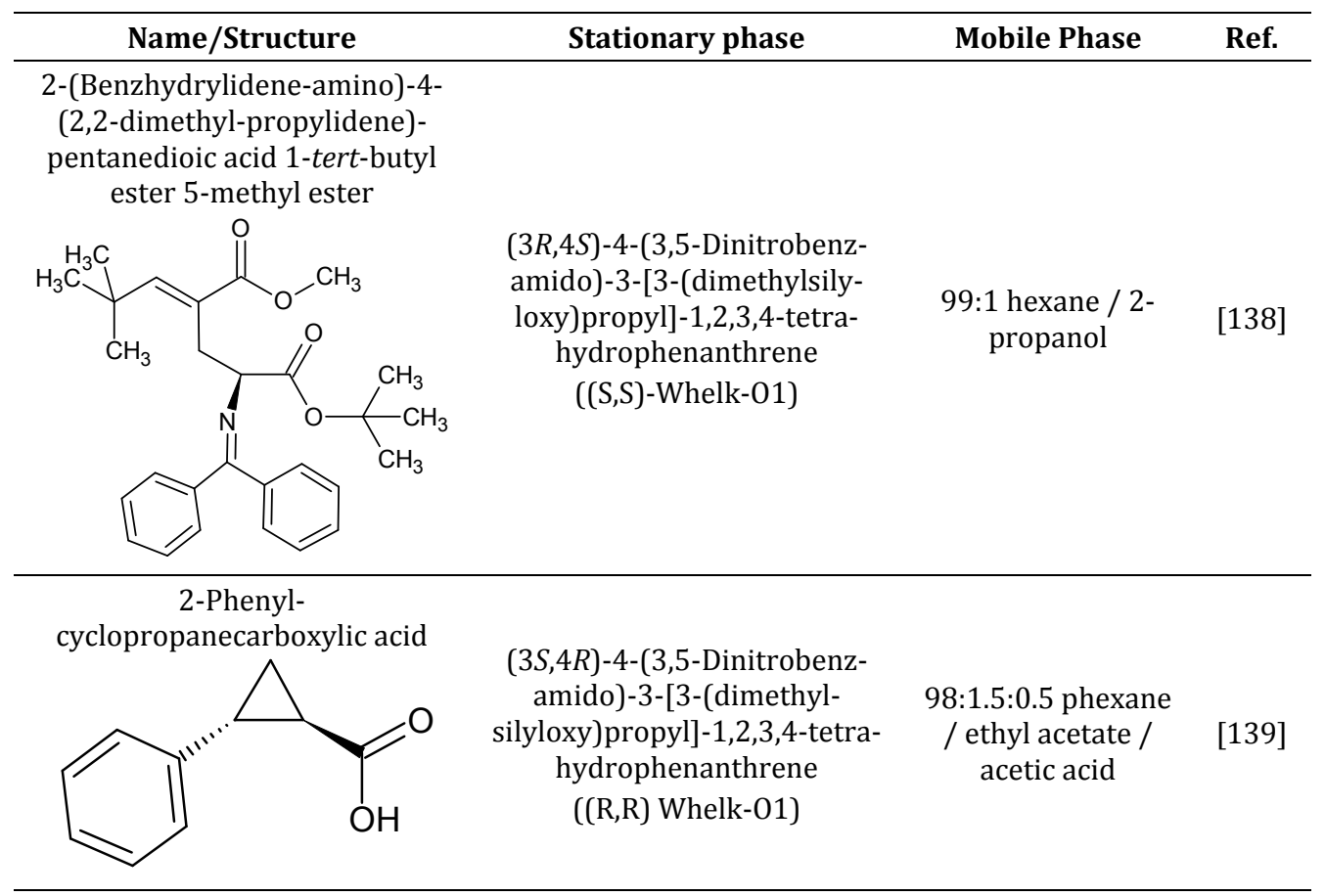

6,6'-Dibromo-1,1'-bi-2naphthol<smiles>Oc1ccc2cc(Br)ccc2c1-c1c(O)ccc2cc(Br)ccc12</smiles>

[(S)-(S)-(1-Acetyl-2-oxo-

cyclopentyl)-m-tolyl-methyl]carbamic acid allyl ester<smiles>C=CCOC(=O)N[C@H](c1cccc(C)c1)[C@@]1(C(C)=O)CCCC1=O</smiles>

(3S,4R)-4-(3,5-Dinitrobenzamido)-3-[3-(trioxysilyl)propyl]-1,2,3,4-tetrahydrophenanthrene

98:2 hexane / 2propanol
(3S,4R)-4-(3,5-Dinitrobenzamido)-3-[3-(dimethylsilyloxy)propyl]-1,2,3,4-tetrahydrophenanthrene

90:10 hexane / 2propanol 


\begin{tabular}{|c|c|c|c|}
\hline Name/Structure & Stationary phase & Mobile Phase & Ref. \\
\hline one & $\begin{array}{c}(3 S, 4 R)-4-(3,5-\text { Dinitrobenz- } \\
\text { amido)-3-[3-(dimethylsily- } \\
\text { loxy)propyl]-1,2,3,4-tetra- } \\
\text { hydrophenanthrene } \\
((\mathrm{R}, \mathrm{R}) \text { Whelk-01) }\end{array}$ & $\begin{array}{c}\text { 0.95:0.95:8:3:87.1 } \\
\text { triethylamine / } \\
\mathrm{H}_{3} \mathrm{PO}_{4} / 2- \\
\text { propanol / } \\
\text { acetonitrile / } \mathrm{H}_{2} \mathrm{O}\end{array}$ & [142] \\
\hline $\begin{array}{r}\text { 1-[2-(3,3-Dimethyl-but- } \\
\text { pyrimidin-5-yl]-2-m } \\
\text { propan-1-ol } \\
\mathrm{H}_{3} \mathrm{C}\end{array}$ & $\begin{array}{l}(3 R, 4 S)-4-(3,5-\text { Dinitrobenz- } \\
\text { amido)-3-[3-(dimethylsily- } \\
\text { loxy)propyl]-1,2,3,4-tetra- } \\
\text { hydrophenanthrene } \\
((\mathrm{S}, \mathrm{S}) \text {-Whelk-01) }\end{array}$ & $\begin{array}{l}\text { Gradient } 4-40 \% \\
\text { methanol (SFC)* }\end{array}$ & [143] \\
\hline
\end{tabular}

4a,7-Dimethyl-1,4,4a,8atetrahydro-1,4-methanonaphthalene-5,8-dione<smiles>CC1=CC(=O)[C@]2(C)[C@@H]3[CH][C@@H](C=C3)[C@H]2C1=O</smiles>

(3R,4S)-4-(3,5-Dinitrobenzamido)-3-[3-(dimethylsilyloxy)propyl]-1,2,3,4-tetrahydrophenanthrene ((S,S)-Whelk-01)
99:1 hexane / 2propanol
2-[(4-Methoxy-phenylamino)phenyl-methyl]-hexanoic acid ethyl ester<smiles>CCCC[C@H](C(=O)OCC)[C@H](Nc1ccc(OC)cc1)c1ccccc1</smiles>

$(3 R, 4 S)-4-(3,5-$ Dinitrobenzamido)-3-[3-(dimethylsilyloxy)propyl]-1,2,3,4tetrahydrophenanthrene ((S,S)-Whelk-01)
99:1 hexane / 2propanol 


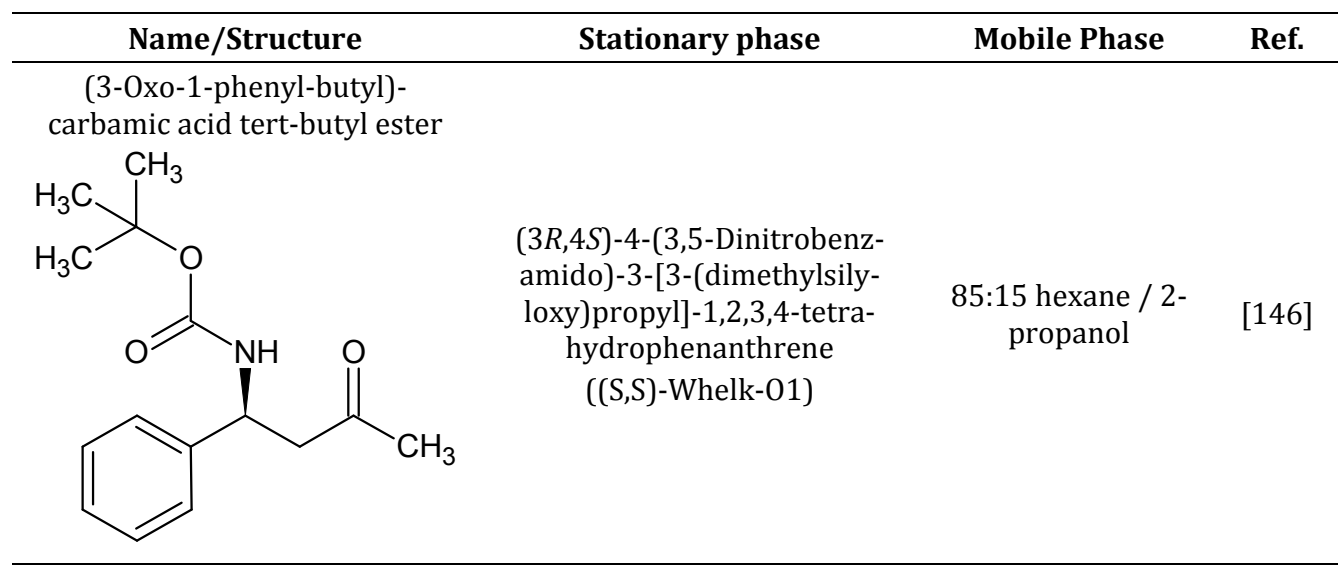

2,2,6,6-Tetramethyl-1-[2,4,4trimethyl-1-(toluene-4sulphonyl)-pyrrolidin-2ylmethoxy]-piperidine<smiles>Cc1ccc(S(=O)(=O)N2CC(C)(C)C[C@]2(C)CON2C(C)(C)CCCC2(C)C)cc1</smiles>

2-(Hydroxy-phenyl-methyl)-5oxo-2,5-dihydro-pyrrole-1carboxylic acid tert-butyl ester<smiles>CC(C)(C)OC(=O)N1C(=O)C=C[C@H]1[C@H](O)c1ccccc1</smiles>

$(3 R, 4 S)-4-(3,5$-Dinitrobenzamido)-3-[3-(dimethylsilyloxy)propyl]-1,2,3,4-tetrahydrophenanthrene ((S,S)-Whelk-01)
97:3 hexane / 2propanol
(3R,4S)-4-(3,5-Dinitrobenzamido)-3-[3-(dimethylsilyloxy)propyl]-1,2,3,4-tetrahydrophenanthrene ((S,S)-Whelk-01)
85:15 hexane / ethanol




Stationary phase
$\begin{gathered}\text { 4-0xo-3-phenyl-3- }((E)-3- \\ \text { phenyl-allyl)-3,4-dihydro-2H- } \\ \text { quinoline-1-carboxylic acid allyl } \\ \text { ester }\end{gathered}$

Methyl -phenyl(prop-2-en-1yloxy)ethanoate<smiles>C=CCO[C@H](C(=O)OC)c1ccccc1</smiles>

(3S,4R)-4-(3,5-Dinitrobenzamido)-3-[3-(dimethylsilyloxy)propyl]-1,2,3,4tetrahydrophenanthrene $((\mathrm{R}, \mathrm{R})$ Whelk-01)
99:1 hexane / 2propanol 
Table 6.6. Selected compounds and the conditions for their HPLC separation on Chiral $\mathrm{AX}^{\circledR} \mathrm{CSP}$ containing quinine

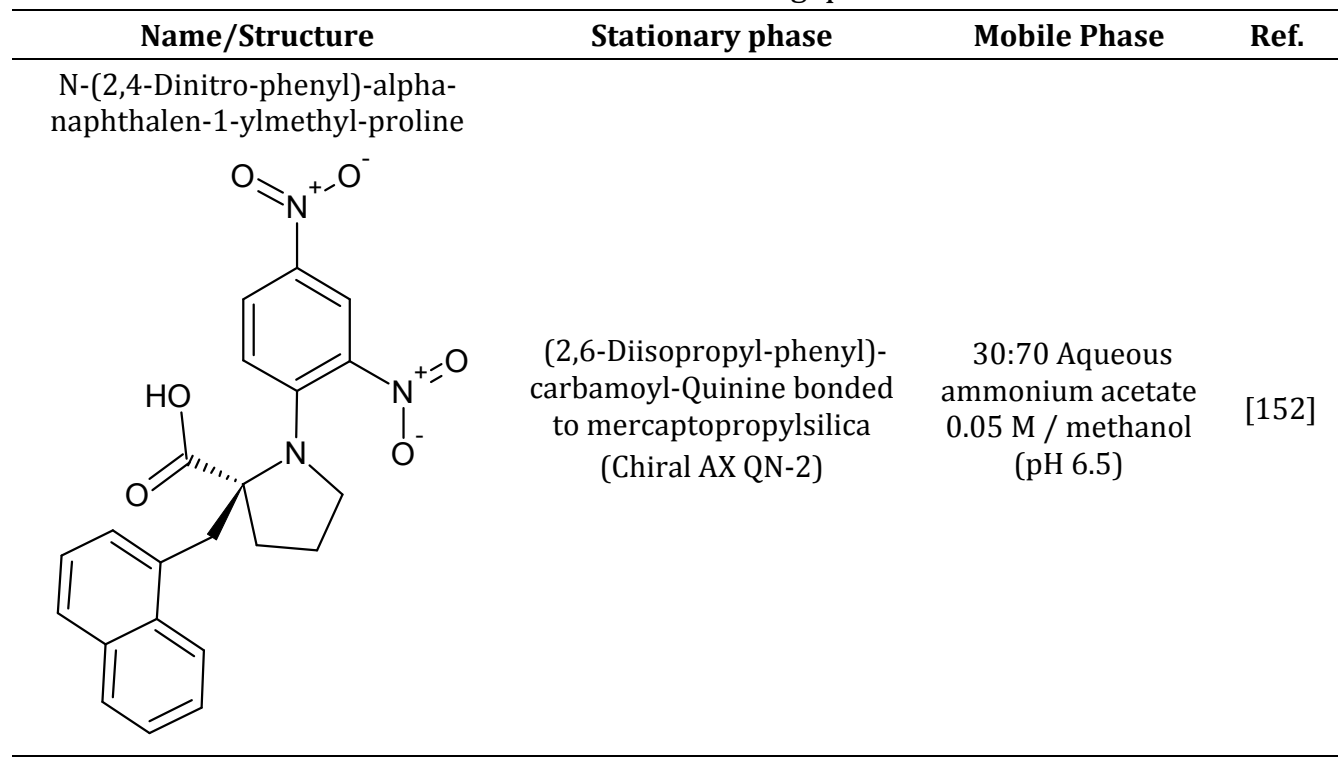

2-Benzyloxycarbonylamino-3phenyl-propionic acid

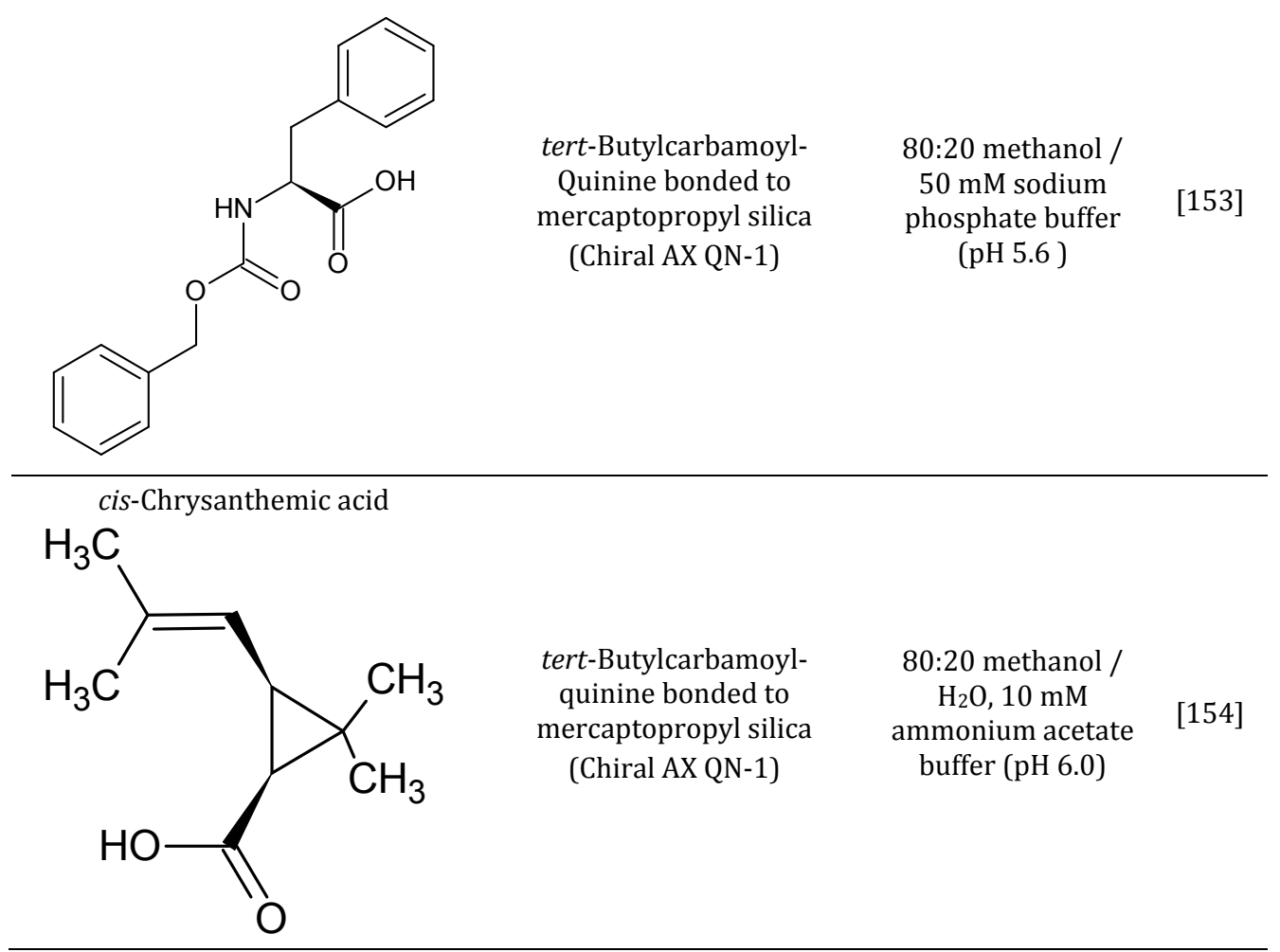




Stationary phase
1-Furan-2-yl-1,2-dihydro-
imidazo[5,1-b]quinazoline-3,9-
dione

Ala-OPA (Alanine ortho-

phthalaldehyde derivative)

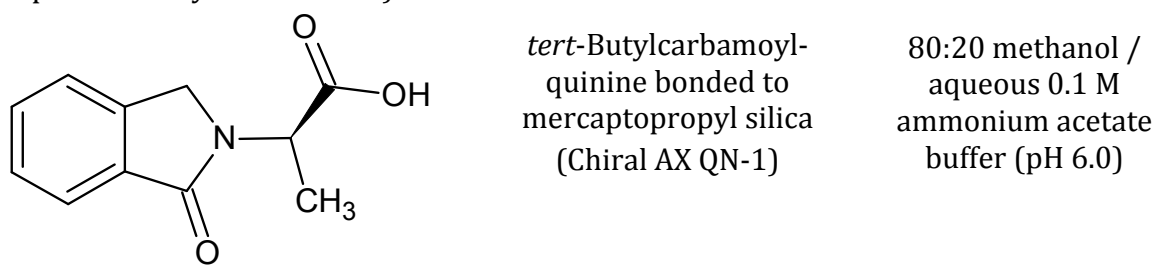

tert-Butylcarbamoyl-

bonded to

(Chiral AX QN-1)

2-Methoxy-2-(1-

naphthyl)propionic acid<smiles>CO[C@@](C)(C(=O)O)c1cccc2ccccc12</smiles>

tert-Butylcarbamoyl-

quinine bonded to mercaptopropyl silica

(Chiral AX QN-1)
96:4 methanol / acetic acid 


\begin{tabular}{|c|c|c|c|}
\hline Name/Structure & Stationary phase & Mobile Phase & Ref. \\
\hline Fmoc-Glu & $\begin{array}{l}\text { tert-Butylcarbamoyl- } \\
\text { quinine bonded to } \\
\text { mercaptopropyl silica } \\
\text { (Chiral AX-QN) }\end{array}$ & $\begin{array}{c}\text { methanol / } 0.25 \% \\
\text { acetic acid ( } 44 \\
\mathrm{mM})\end{array}$ & [158] \\
\hline
\end{tabular}

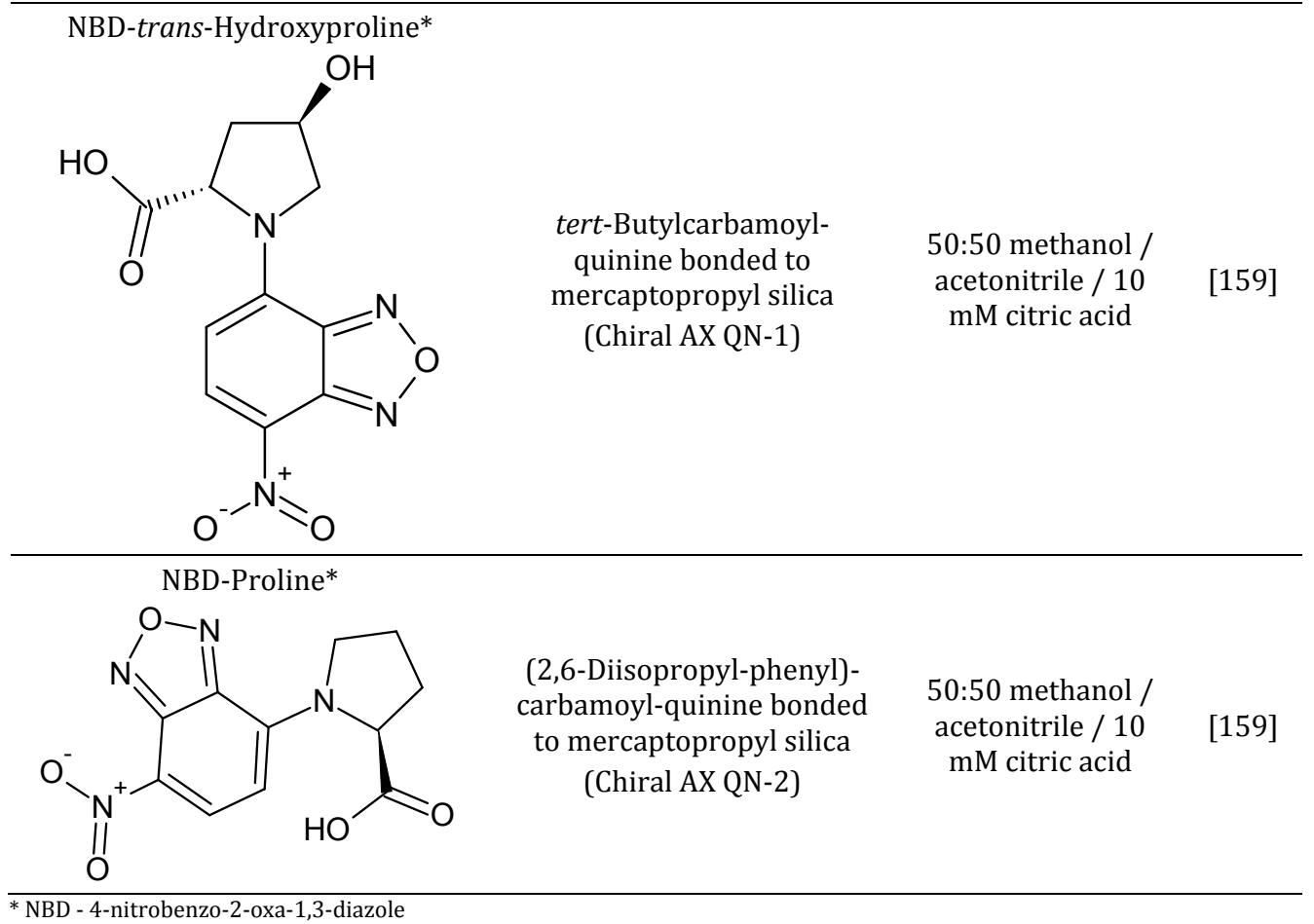

\subsubsection{Ligand exchange}

Ligand exchange chromatography (LEC) is a typical example of complexation chromatography. Complexes formed during LEC encompass a metal cation associated with ligands (anions or neutral molecules) able to donate electron pairs to a vacant orbital of the metal [160]. The term ligand exchange was introduced Helfferich in 1961 when he described the substitution of organic diamine molecules with metal ion-coordinated molecules containing amine groups in a polymeric phase [161]. The technique was further developed by Davankov and Rogozin for the separation of enantiomers [162]. This technique is applicable to those enantiomers which are able to form metal complexes with the moiety bound onto the stationary phase. Enantiomeric analytes such as amino acids and hydroxy acids were successfully separated into enantiomers using LEC. 
In their paper, the authors described the model of interaction during the enantiomeric separation with LEC [162]:

"In such a process, one ligand (the optically active one) should be rigidly attached to a stationary phase, while the other (racemic) ligand should be able to move with the mobile phase. The metal atom forming the complex may be combined with either ligand. The important point is that the complex generated should be kinetically labile, i.e. readily decomposed and reformed."

Based on the model, the chiral phase is usually an amino acid anchored to a silica matrix through a spacer. Table 6.7 shows several examples of enantiomeric separations through LEC. The mobile phase used in conjunction with these chiral phases is a buffer containing millimolar amounts of copper. At a constant $\mathrm{pH}$, the retention increases with an increase in the length of the spacer. The $\mathrm{pH}$ of the mobile phase influences the stability constant of the complexes and, consequently, the retention as well as the enantioselectivity. The retention of hydrophobic analytes can be controlled by the amount of an organic modifier such as acetonitrile or methanol. The flow rate of the mobile phase has major role on the resolution; the slower the flow rate, the higher the resolution [163].

Table 6.7. Conditions for LEC enantiomeric separation of selected compounds

\begin{tabular}{cccc}
\hline Name/Structure & Stationary Phase & Mobile Phase & Ref. \\
\hline 5.5-Dimethylthiazolidine-4- & & & \\
carboxylic acid & $\begin{array}{c}(S) \text {-Leucinol monosodium } \\
\text { salt covalently bonded to } \\
\text { aminoundecyl silica }\end{array}$ & $\begin{array}{c}80: 20 \text { aqueous } \mathrm{CuSO}_{4} \\
0.2 \mathrm{mM} / \text { methanol }\end{array}$ & {$[164]$} \\
& & &
\end{tabular}

$2 R, 3 R-2 S, 3 S-2$-Hydroxy-3-

methyl-pentanoic acid<smiles>CC[C@H](C)[C@H](O)C(=O)O</smiles>

$\mathrm{N}, \mathrm{N}$-Dioctyl- $L$-alanine coated octadecyl silica

(Chiralpak MA(+))
85:15 $2 \mathrm{mM} \mathrm{CuSO}_{4} /$ acetonitrile

N-Methyl glutamic acid<smiles>CN[C@@H](CCC(=O)O)C(=O)O</smiles>

$\mathrm{N}, \mathrm{S}$-Dioctyl- $(D)$ penicillamine coated on octadecylsilanised silica

(Chirex 3126)
90:10 $2 \mathrm{mM} \mathrm{CuSO}_{4} /$ acetonitrile
[166] 


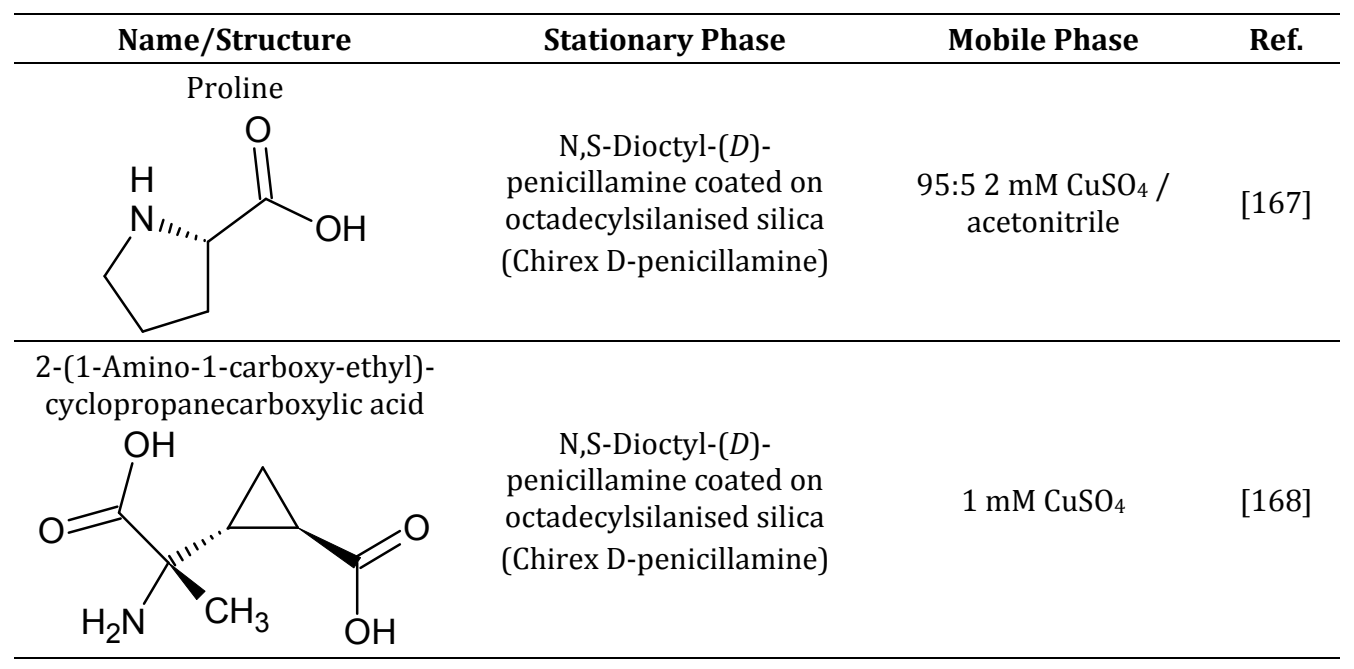

2-Amino-4-methylselanylbutyric acid<smiles>C[Se]CC[C@H](N)C(=O)O</smiles>

Isoleucine reacted on $(3,4-$ epoxycyclohexyl)ethyltrime thoxy-silane reacted on silica
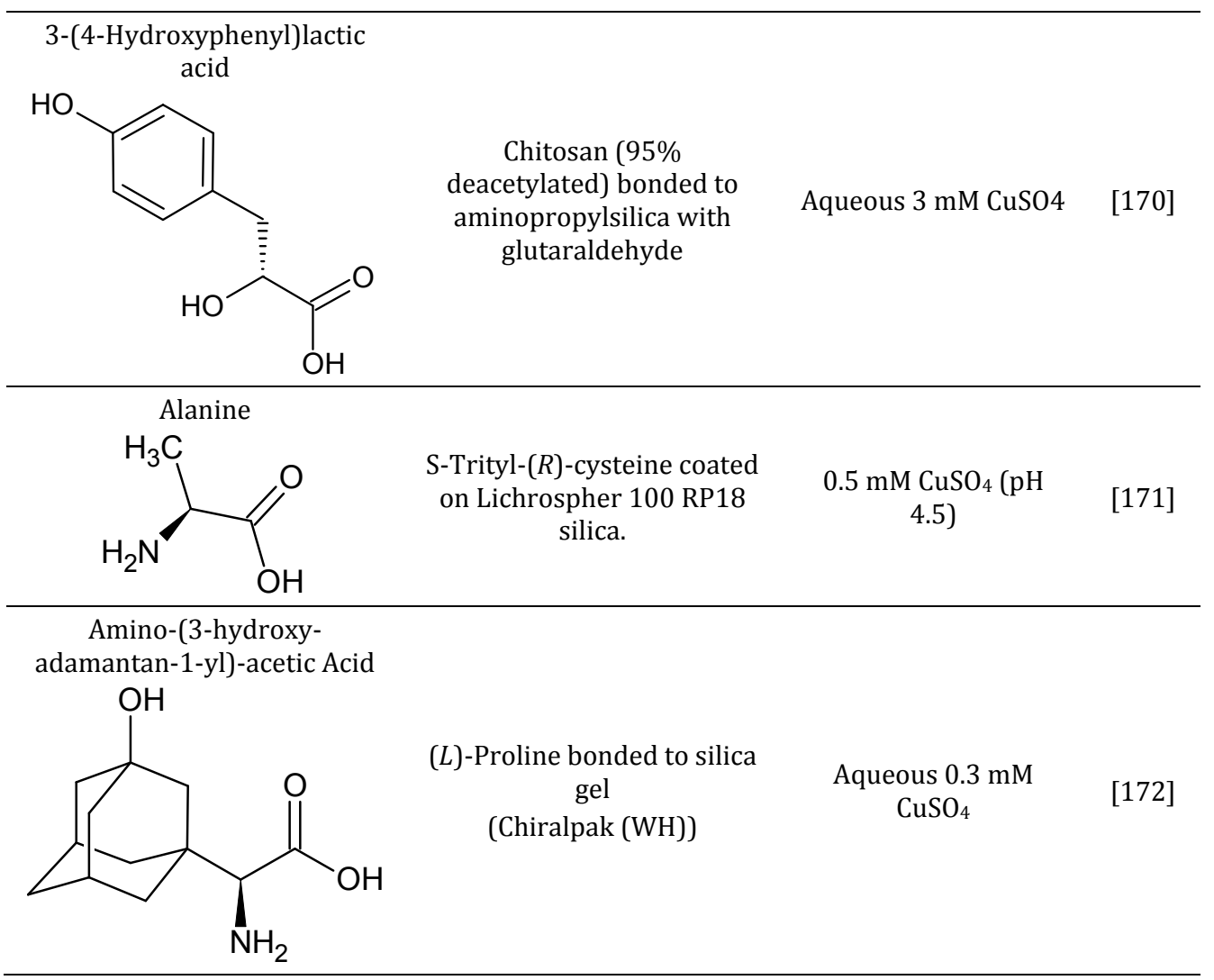


\subsubsection{Mixed types of interactions}

The previous sections described the main types of interactions occurring between the enantiomeric analytes and the stationary phase (hydrogen bonding, inclusion complexes, charge transfer and ligand exchange). In the following section, we will present enantiomeric separation based on combinations of these interactions. These types of stationary phases include polysaccharides, antibiotic phases (macrocyclic antibiotics) and protein phases.

\subsubsection{Polysaccharide phases}

Many polysaccharides serve as extracellular elements in the cell walls of unicellular microorganisms and higher plants and on the outer surfaces of animal cells. There are many different structural polysaccharides. Cellulose is the most abundant extracellular structural polysaccharide of all biomolecules, plant or animal. Structurally, cellulose is a polysaccharide composed of several thousand molecules of D-glucose joined by $\beta(1 \rightarrow 4)$ glycosidic linkages. Complete hydrolysis of all glycosidic bonds of cellulose yields D-glucose.

Starch is a mixture of a water-dispersible fraction called amylose and a second component, amylopectin. Amylose is a polysaccharide made up of about 100 to several thousand D-glucose units joined together by $\alpha(1 \rightarrow 4)$ glycosidic bonds [173]. This difference in the structure of cellulose and amylose results in polymeric structures with very different properties. Because of their $\beta$ linkages, the D-glucose chains in cellulose assume an extended conformation and undergo side-by-side aggregation due to hydrogen bonding between the hydroxyl groups of adjacent cellulose chains. Due to the geometry of their $\alpha(1 \rightarrow 4)$ linkages, the main chains of D-glucose units in amylose tend to assume a coiled, helical conformation [174].

Cellulose has been used in thin layer chromatography to separate enantiomers of tryptophan and tryptophan derivatives using aqueous mobile phases [175-177], while amylose has been used to separate biphenyl atropisomers and other optical isomers [178]. The interactions between the enantiomeric analytes and these chiral stationary phases occur only through $\mathrm{H}$-bonding as well as inclusion between the polymeric chains of these biomolecules. The chiral discrimination of these native biopolymers is thereby reduced. Modification of hydroxy groups through esters or carbamate formation greatly enhances the enantioselective properties of these polysaccharides due to multiple possibilities of H-bonds and $\pi-\pi$ interactions as well as through inclusion complex formations. Phenyl esters and phenyl carbamates of amylose and cellulose are the most popular CSPs today. For example, the major chiral adsorption site in cellulose trismethylbenzoate is considered to be the polar carbonyl groups of the esters, which can interact with the racemate through hydrogen bonding and dipoledipole interactions for discrimination between enantiomers [179]. The cellulose and amylose carbamate assume a left-handed three-fold helical conformation, while the corresponding amylose has a left-handed four-fold helix. A chiral helical 
channel is formed along the backbone. Aromatic moieties are located at the surface of the chain while the polar groups are located in the interior [180]. The shape of the chiral cavities varies depending on the nature of the substitution on the polysaccharide [125]. Chiral recognition is attributed to shape-selective inclusion along with $\pi-\pi$ interactions, hydrogen bonding and van der Waals interactions [181]. These stationary phases operate under normal phase as well as under reversed phase mobile phase conditions. Under normal phase conditions, combinations of hexane/alcohols are used. Under reversed phase conditions, it is assumed that the interaction between the CSP and the enantiomeric analytes occurs through shape-specific interactions into the chiral cavities [182].

Tables 6.8 - 6.19 give some selected examples of enantiomeric separation using cellulose derivatised and amylase derivaziesd CSPs.

Table 6.8. Conditions for chiral separations of selected compounds using cellulose tris(3,5dimethylphenylcarbamate)/macroporous silica gel (Chiralcel OD ${ }^{\circledR}$ ) stationary phase

\begin{tabular}{|c|c|c|c|}
\hline Name & Structure & Mobile Phase & Ref. \\
\hline $\begin{array}{c}\text { 1-[[4-(4-Chloro-phenyl)-1- } \\
\text { methyl-1H-pyrrol-3-yl]- } \\
\text { phenyl-methyl]-1H- } \\
\text { imidazole }\end{array}$ & & $\begin{array}{c}90: 10 \text { hexane / ethanol / } \\
0.1 \% \text { diethylamine }\end{array}$ & [183] \\
\hline Indapamide & & 50:50 hexane / ethanol & [184] \\
\hline $\begin{array}{c}\text { Dia- }(1 S 3 R, 1 R 3 R) \text {-3-benzyl- } \\
\text { oxymethyl-1,3-dihydro- } \\
\text { isobenzofuran-1-thymine }\end{array}$ & & $80: 20$ hexane / ethanol & [185] \\
\hline $\begin{array}{c}\text { Dia-(1R3R,1S3R)-3-benzyl- } \\
\text { oxymethyl-1,3-dihydro- } \\
\text { isobenzofuran-1-uracil }\end{array}$ & & $80: 20$ hexane / ethanol & [185] \\
\hline
\end{tabular}




\begin{tabular}{|c|c|c|c|}
\hline Name & Structure & Mobile Phase & Ref. \\
\hline $\begin{array}{l}\text { 5,7-Dimethyl-1,4-dioxo- } \\
\text { 1,5,8,8a-tetrahydro-4H- } \\
\text { naphthalene-4a-carboxylic } \\
\text { acid methyl ester }\end{array}$ & & 95:5 hexane / 2-propanol & [186] \\
\hline $\begin{array}{l}\text { 5-(N,N'-Bisbenzyloxy- } \\
\text { carbonyl-hydrazino)-4- } \\
\text { hydroxy-heptan-2-one }\end{array}$ & & $\begin{array}{c}\text { 60:40:0.1 } \mathrm{H}_{2} \mathrm{O} / \\
\text { acetonitrile / tri-fluoro } \\
\text { acetic acid }\end{array}$ & [187] \\
\hline
\end{tabular}

3-Methyl-1,3,4-triphenylbutan-1-one

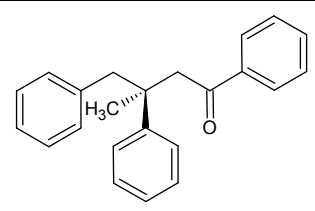

85:15 hexane / methyl-tbutyl ether

5-(3,5-Dinitro-benzoyloxy)3-aza-tricyclo[2.2.1.0*2,6*] heptane-3-carboxylic acid tert-butyl ester<smiles>CC(C)(C)OC(=O)N1CC2C=CC1C2</smiles><smiles>COC(=O)c1cc([N+](=O)[O-])cc([N+](=O)[O-])c1</smiles>

50:50 hexane / ethanol

Diniconazole

\begin{tabular}{c} 
Diniconazole \\
\hline Phosphinamide derivative
\end{tabular}<smiles>CC(C)(C)[C@H](O)/C(=C\c1ccc(Cl)cc1Cl)n1cncn1</smiles>

85:15 hexane / ethyl acetate

90:10 hexane / 2propanol<smiles>Cc1cc(C)cc(P(=O)(NC(C)c2ccccc2)c2cc(C)cc(C)c2)c1</smiles> 


\begin{tabular}{|c|c|c|c|}
\hline Name & Structure & Mobile Phase & Ref. \\
\hline $\begin{array}{l}\text { (5-Methyl-4,5-dihydro- } \\
\text { pyrazol-1-yl)-pyridin-3-yl- } \\
\text { methanone }\end{array}$ & & $\begin{array}{l}\text { 90:10 hexane / 2- } \\
\text { propanol }\end{array}$ & [192] \\
\hline $\begin{array}{l}\text { 1-(4-Chloro-phenyl)-3- } \\
\text { phenyl-propane-1,3-diol }\end{array}$ & & 95:5 hexane / 2-propanol & [193] \\
\hline $\begin{array}{c}\text { 6-Chloro-2,2-dimethyl- } \\
\text { 1a,7b-dihydro-2H-1,3- } \\
\text { dioxa- } \\
\text { cyclopropa[a]naphthalene }\end{array}$ & & 99:1 hexane / 2-propanol & [194] \\
\hline $\begin{array}{c}\text { 1-(1-Methyl-1H-imidazol-2- } \\
\text { yl)-2-(2,3,4,9-tetrahydro- } \\
\text { 1H-carbazol-1-yl)-ethanone }\end{array}$ & & $\begin{array}{l}\text { 90:10 hexanes / 2- } \\
\text { propanol }\end{array}$ & [195] \\
\hline Nadolol & & $100 \%$ acetonitrile & [196] \\
\hline $\begin{array}{c}\text { (1-Isobutyl-pyrrolidin-2-yl)- } \\
\text { phenyl-methanol }\end{array}$ & & $\begin{array}{l}\text { 99.5:0.5 hexane / 2- } \\
\text { propanol }\end{array}$ & [197] \\
\hline
\end{tabular}

Acetic acid 2-benzyl-3-(tertbutyl-dimethyl-silanyloxy)propyl ester<smiles>CC(=O)OCC(CO[Si](C)(C)C(C)(C)C)Cc1ccccc1</smiles>

3-Furan-2-yl-2,3-dihydrobenzofuran-3-ol<smiles>O[C@@]1(c2ccco2)COc2ccccc21</smiles>

90:10 hexane / 2propanol 


\begin{tabular}{|c|c|c|c|}
\hline Name & Structure & Mobile Phase & Ref. \\
\hline $\begin{array}{l}\text { 4-Acetyl-5-ethyl-3-hydroxy- } \\
\text { 2,3-dihydro-furan-3- } \\
\text { carboxylic acid ethyl ester }\end{array}$ & & 95:5 hexane / 2-propanol & [200] \\
\hline $\begin{array}{l}\text { Indan-1-yl-carbamic acid } \\
\text { 2,2,2-trichloro-ethyl ester }\end{array}$ & & 9:1 hexane / 2-propanol & [201] \\
\hline $\begin{array}{l}\text { 3-Phenethyl-decanoic acid } \\
\text { methyl ester }\end{array}$ & & $\begin{array}{l}\text { 99.2:0.8 hexane / 2- } \\
\text { propanol }\end{array}$ & [202] \\
\hline $\begin{array}{l}\text { (3,5-Dimethyl-phenyl)-(1- } \\
\text { phenyl-ethyl)-amine }\end{array}$ & & 99:1 hexane / 2-propanol & [203] \\
\hline $\begin{array}{l}\text { 3-[4-Methyl-3-[methyl- }(7 \mathrm{H}- \\
\text { pyrrolo[2,3-d]pyrimidin-4- } \\
\text { yl)-amino]-piperidin-1-yl]- } \\
\text { 3-oxo-propionitrile }\end{array}$ & & methanol & [204] \\
\hline
\end{tabular}

2,2,4-Trimethyl-4-(2phenyl-allyl)-[1,3]dioxan-5one<smiles>c1ccccc1</smiles>

2-(Benzoyl-methyl-amino)3-methyl-butyric acid methyl ester<smiles>C=C(C)C(=C)C[C@]1(C)OC(C)(C)OCC1=O</smiles><smiles>COC(=O)C(C(C)C)N(C)C(=O)c1ccccc1</smiles> 


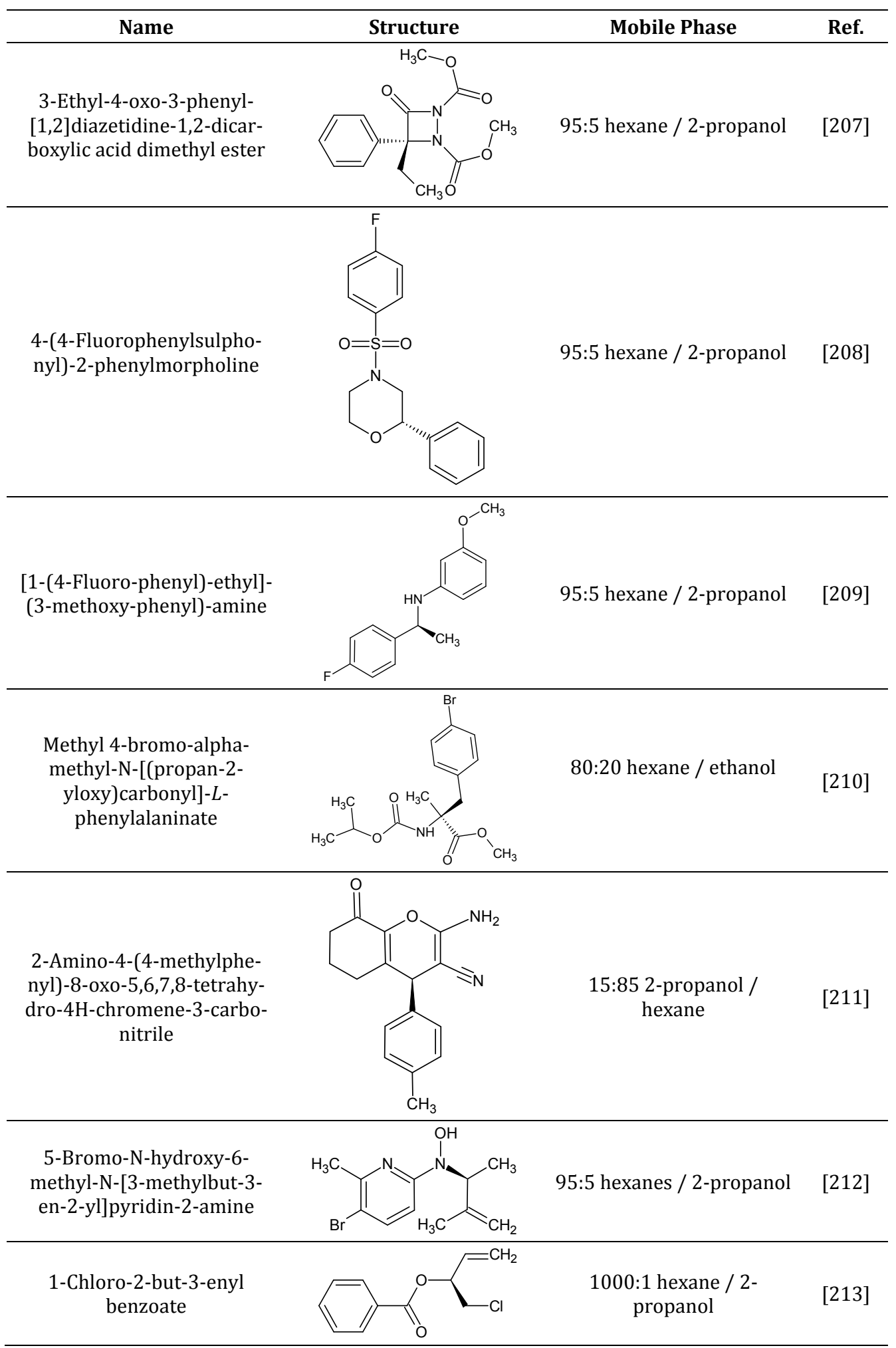


Table 6.9. Conditions for chiral separations of selected compounds using amylose tris(3,5-dimethylphenylcarbamate) coated on silica (Chiralpak AD ${ }^{\circledR}$ ) stationary phase

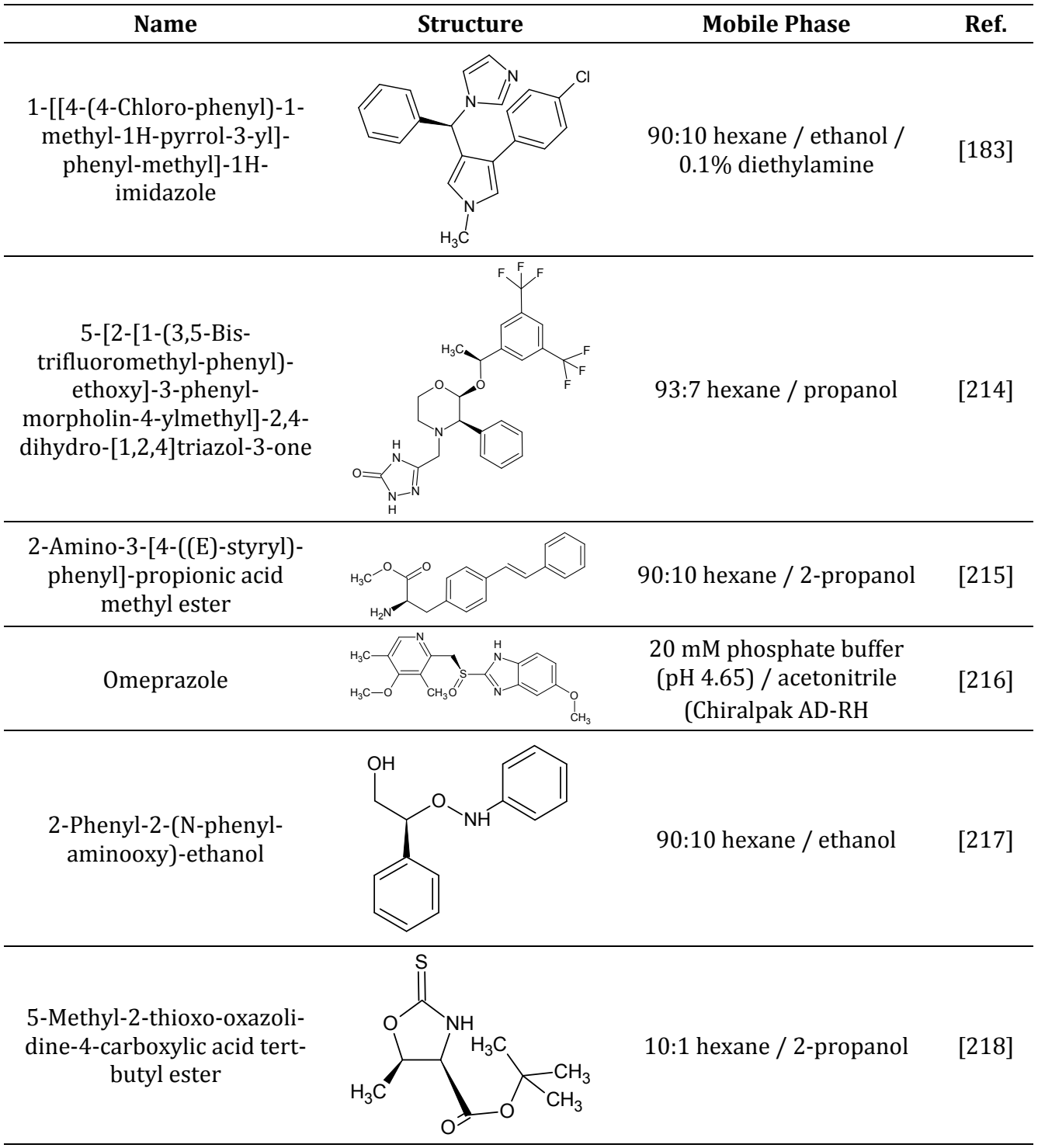

3-Phenyl-propane-1,2-diol<smiles>OC[C@H](O)Cc1ccccc1</smiles>

98:2 hexane / 2-propanol

1,2-Di-furan-2-yl-2hydroxy-ethanone<smiles>O=C(c1ccco1)C(O)c1ccco1</smiles> 


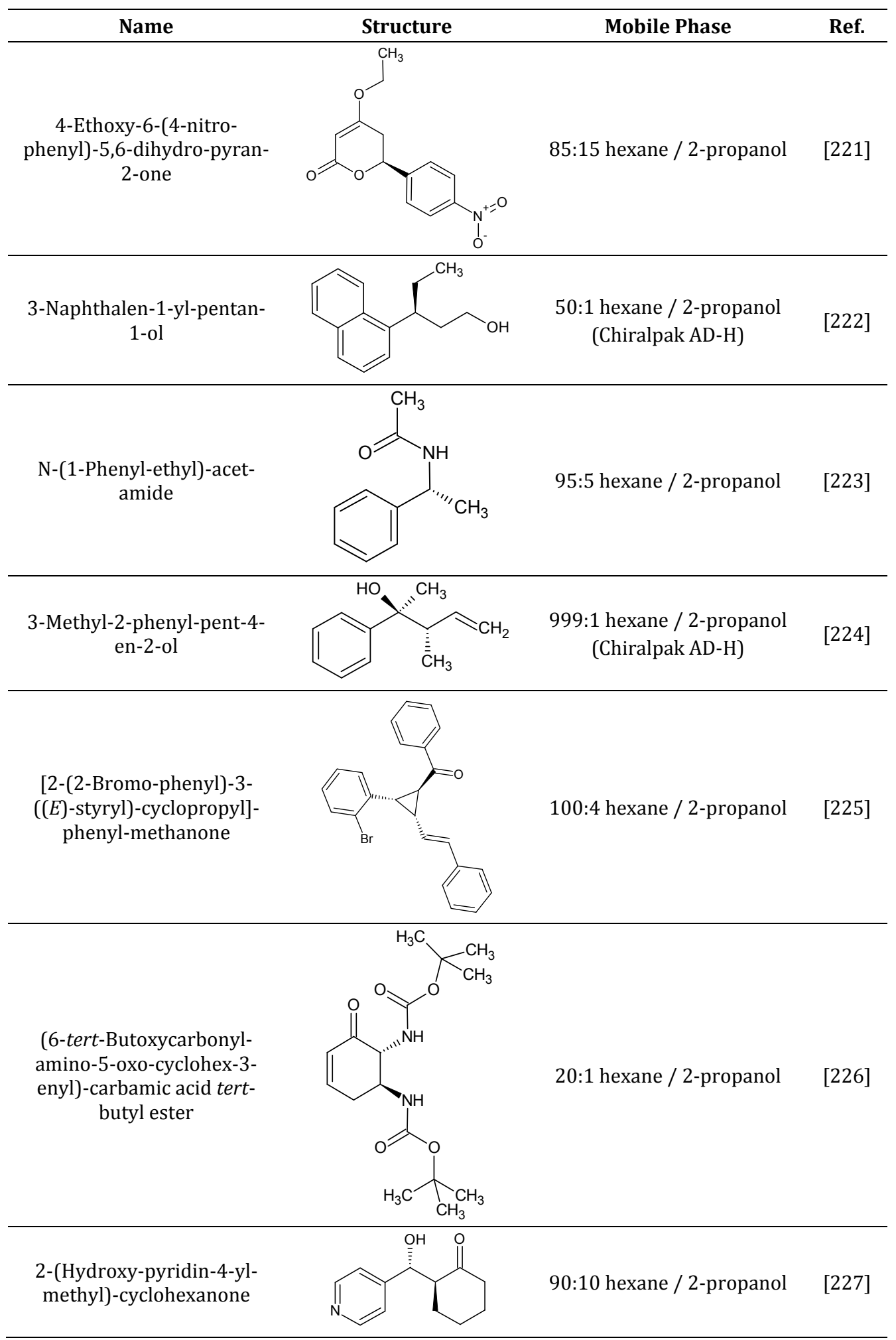




\begin{tabular}{|c|c|c|c|}
\hline Name & Structure & Mobile Phase & Ref. \\
\hline $\begin{array}{c}\text { 5-(N-Phenyl-aminooxy)- } \\
\text { hept-1-en-4-ol }\end{array}$ & & 97:3 hexanes / 2-propanol & [228] \\
\hline $\begin{array}{l}\text { Efaroxan 2-(2-Ethyl-2,3- } \\
\text { dihydro-benzofuran-2-yl)- } \\
\text { 4,5-dihydro-1H-imidazole }\end{array}$ & & $\begin{array}{l}\text { 98:2:0.05 hexane / 2- } \\
\text { propanol / diethylamine }\end{array}$ & [229] \\
\hline $\begin{array}{l}\text { Diarylphosphinamide } \\
\text { derivative }\end{array}$ & & 50:1 hexane / 2-propanol & [230] \\
\hline $\begin{array}{l}\text { 1-Methyl-2,4,5-triphenyl- } \\
\text { 4,5-dihydro-1H-imidazole }\end{array}$ & & 90:10 heptane / 2-propanol & [231] \\
\hline $\begin{array}{l}\text { 2-[(1H-Indol-3-yl)-phenyl- } \\
\text { methyl]-3-methyl-butyr- } \\
\text { aldehyde }\end{array}$ & & 85:15 hexane / 2-propanol & [232] \\
\hline $\begin{array}{l}\text { 2-[Hydroxy-(4-nitro- } \\
\text { phenyl)-methyl]-cyclo- } \\
\text { pentanone }\end{array}$ & & 95:5 hexane / 2-propanol & [233] \\
\hline $\begin{array}{l}\text { 2-Ethyl-3-methyl-5-phenyl- } \\
\text { pyrrolidine-2,4-dicarboxylic } \\
\text { acid dimethyl ester }\end{array}$ & & 40:1 hexane / 2-propanol & [234] \\
\hline
\end{tabular}




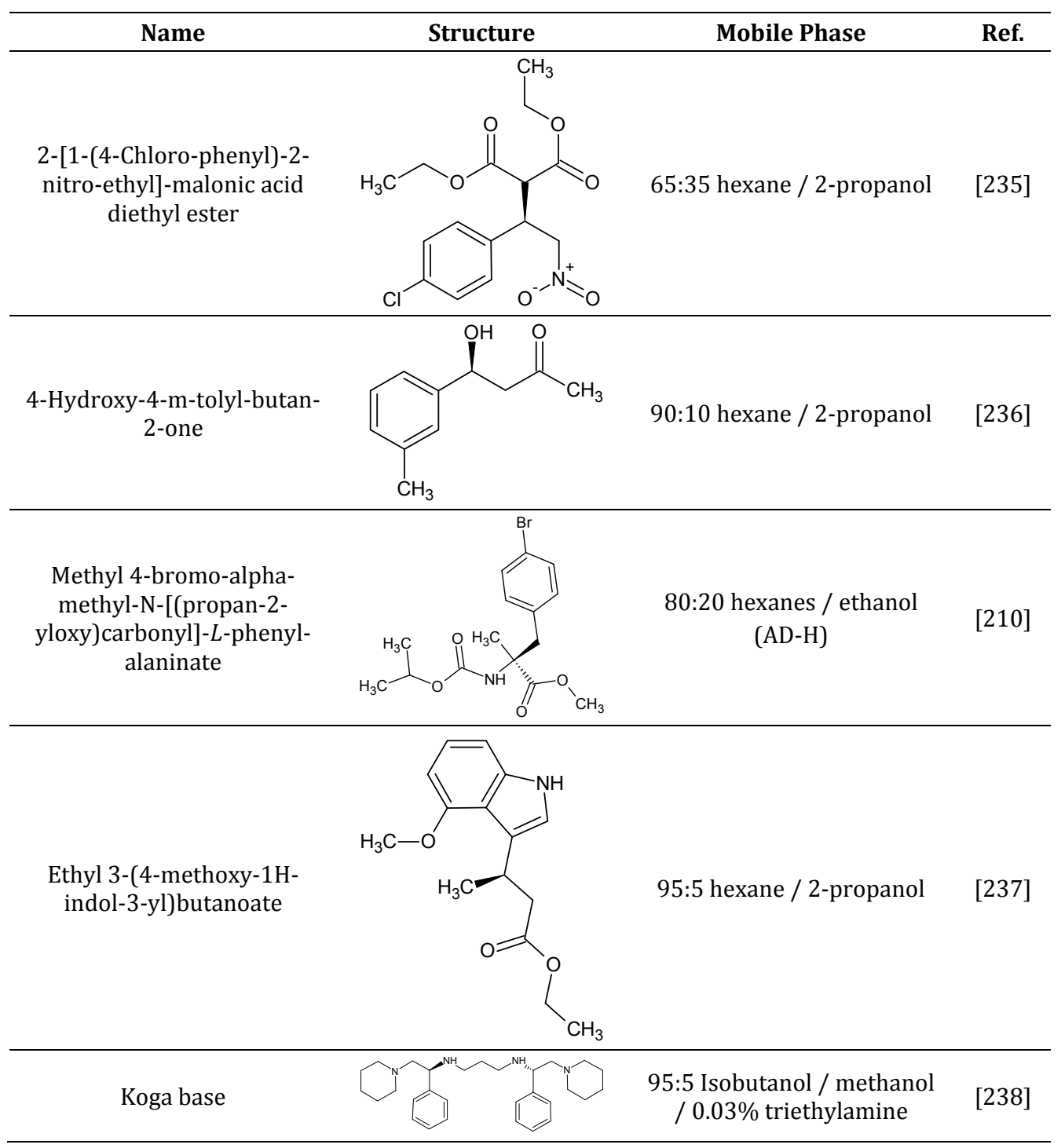


Table 6.10. Conditions for chiral separations of selected compounds using cellulose tris(3,5-dimethylphenylcarbamate) immobilised on silica

(Chiralpak IB ${ }^{\circledR}$ ) stationary phase

Name
$\begin{aligned} & \text { 5-Ethyl-1-methyl-5-propyl- } \\ & \text { pyrimidine-2,4,6-trione }\end{aligned}$ [239]
dih- -Methoxy-1,alpha-
[240]

7b-Phenyl-1a,2,3,7b-

tetrahydro-1-oxa-

cyclopropa[a]naphthalene

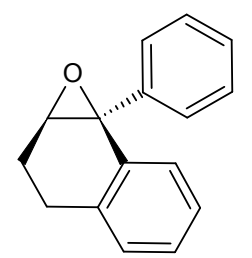

95:5 hexane / 2-propanol

[242]

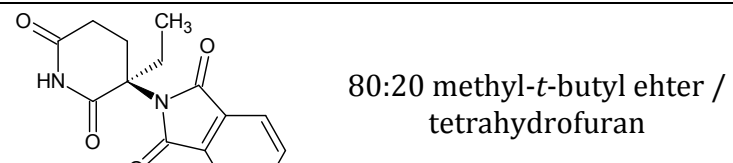

[243] piperidin-3-yl)-isoindole-1,3dione<smiles>O=CC1C=CCCC1</smiles><smiles>CC(C)[C@H](C(=O)O)N1C(=O)c2ccccc2C1=O</smiles>

95:5 hexane / 2-propanol / $0.1 \% \mathrm{CF}_{3} \mathrm{CO}_{2} \mathrm{H}$ 2-methyl-3-phenyl-propan-1ol<smiles>COc1ccc(N[C@@H](c2ccccc2)[C@H](C)CO)cc1</smiles> 


\begin{tabular}{|c|c|c|c|}
\hline Name & Structure & Mobile Phase & Ref. \\
\hline $\begin{array}{l}\text { 4-[[Carboxy-(3,4-dimethoxy- } \\
\text { phenyl)-methyl]-carbamoyl]- } \\
\text { butyric acid }\end{array}$ & & $\begin{array}{c}\text { 66:30:4:0.1 hexane } / \mathrm{CHCl}_{3} \\
\text { / ethanol / trifluoroacetic } \\
\text { acid }\end{array}$ & [245] \\
\hline Metanephrine & & $\begin{array}{c}\text { 65:35:0.1 hexane / ethanol } \\
\text { / diethylamine }\end{array}$ & [246] \\
\hline BOC-Phg-Oet & & $\begin{array}{c}\text { 40:60 methyl-t-butyl ehter / } \\
\text { hexane / } 0.1 \% \\
\text { trifluoroacetic acid }\end{array}$ & [247] \\
\hline $\begin{array}{l}\text { 3-(4-Methoxy-phenyl)-1,4- } \\
\text { diphenyl-azetidin-2-one }\end{array}$ & & hexane / 2-propanol & [248] \\
\hline $\begin{array}{l}\text { (Cyclobutyl-phenyl-methyl)- } \\
\text { (4-methoxy-phenyl)-amine }\end{array}$ & & 99:1 hexane / 2-propanol & [249] \\
\hline Flurbiprofen $n$-butyl ester & & $\begin{array}{l}\text { 85:15:0.4:0.1 hexane / tert- } \\
\text { butyl methyl ether / 2- } \\
\text { propanol / trifluoroacetic } \\
\text { acid }\end{array}$ & [250] \\
\hline $\begin{array}{l}\text { (7E)-6-Hydroxytetradec-7- } \\
\text { ene-2,4-diyn-1-yl acetate }\end{array}$ & & $\begin{array}{c}\text { 90:10 heptane / ethyl } \\
\text { acetate }\end{array}$ & [251] \\
\hline
\end{tabular}


Table 6.11. Conditions for chiral separations of selected compounds using amylose tris(3,5-dimethylphenylcarbamate) immobilised on silica

(Chiralpak IA ${ }^{\circledR}$ ) stationary phase

\begin{tabular}{|c|c|c|c|}
\hline Name & Structure & Mobile Phase & Ref. \\
\hline $\begin{array}{l}\text { 3,5-Dinitro-benzoic acid 2- } \\
\text { phenyl-1-trifluoromethyl- } \\
\text { cyclopropylmethyl ester }\end{array}$ & & 90:10 hexane / 2-propanol & [252] \\
\hline Pirprofen & & $\begin{array}{l}\text { 80:20:0.1 hexane / 2- } \\
\text { propanol / trifluoroacetic } \\
\text { acid }\end{array}$ & [253] \\
\hline Propafenone & & $\begin{array}{c}\text { 60:40:0.1 hexane / } \\
\text { tetrahydrofuran / } \\
\text { diethylamine }\end{array}$ & [254] \\
\hline
\end{tabular}

[1]Benzothieno[5',4':2,3][1]b enzothieno[5,4-b]thieno[3,2e][1]benzothiophene

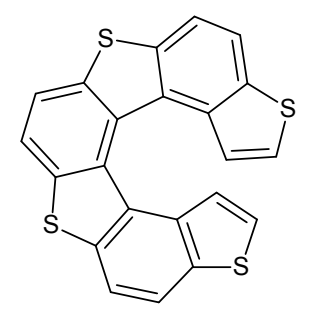

19:1 hexane / dichloromethane

3-[[7-Ethyl-5-methoxy-9-oxo6,7,8,9-tetrahydro-5H-5,8epoxybenzo[7]annulen-6yl]carbonyl]-1,3-oxazolidin-2one

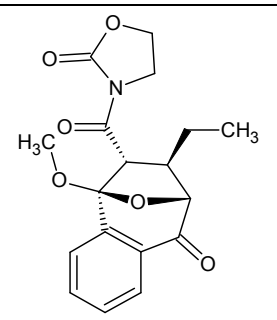

80:20 hexane / 2-propanol

3-p-Tolyl-cyclohexanone

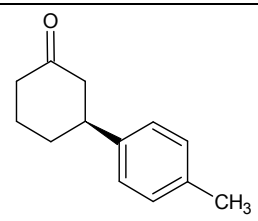

98:2 hexane / 2-propanol 


\begin{tabular}{|c|c|c|c|}
\hline Name & Structure & Mobile Phase & Ref. \\
\hline Rabeprazole & & $\begin{array}{l}\text { 80:20:0.1 heptane / 2- } \\
\text { propanol / triethylamine }\end{array}$ & [258] \\
\hline $\begin{array}{c}\text { 2-(3-Ethyl-2,6-dioxo- } \\
\text { piperidin-3-yl)-isoindole-1,3- } \\
\text { dione }\end{array}$ & & $\begin{array}{l}80: 20 \mathrm{CH}_{2} \mathrm{Cl}_{2} / \\
\text { tetrahydrofuran }\end{array}$ & [259] \\
\hline $\begin{array}{c}\text { [(4-Isopropoxy- } \\
\text { phenylamino)-phenyl- } \\
\text { methyl]-phosphonic acid } \\
\text { dimethyl ester }\end{array}$ & & 9:1 hexane / 2-propanol & [260] \\
\hline Flavanone & & $\begin{array}{c}90: 10 \text { methanol / } 10 \mathrm{mM} \\
\text { sodium phosphate } \\
\left(\mathrm{Na}_{2} \mathrm{HPO}_{4}+\mathrm{NaH}_{2} \mathrm{PO}_{4}\right) \\
\text { buffer pH } 3.0(\mathrm{pH} \text { adjusted } \\
\text { with } 0.1 \mathrm{~N} \mathrm{NaOH} \text { or } \\
\left.10 \% \mathrm{H}_{3} \mathrm{PO}_{4}\right)\end{array}$ & [261] \\
\hline 1-Phenylethanol & & 95:5 hexane / 2-propanol & [262] \\
\hline $\begin{array}{l}\text { 4-Cyclohexyl-4-hydroxy- } \\
\text { butan-2-one }\end{array}$ & & 90:10 heptane / 2-propanol & [263] \\
\hline $\begin{array}{l}\text { 2,4,5-Triphenyl-1-(toluene-4- } \\
\text { sulphonyl)-4,5-dihydro-1H- } \\
\text { imidazole }\end{array}$ & & 75:25 heptane / 2-propanol & [231] \\
\hline BOC-Val-Oet & & $\begin{array}{c}\text { 40:60 methyl-t-butyl ehter / } \\
\text { hexane / } 0.1 \% \\
\text { trifluoroacetic acid }\end{array}$ & [247] \\
\hline
\end{tabular}




\begin{tabular}{cccc}
\hline Name & Mobile Phase & Ref. \\
\hline (Phenylthio)cyclopentanone & & \\
\hline-
\end{tabular}

$\left.\begin{array}{l}\text { 2-(N-Phenyl-aminooxy)- } \\ \text { hexan-1-ol }\end{array}\right]$ [265]

Table 6.12. Conditions for chiral separations of selected compounds using cellulose tris(4-methyl-benzoate) coated on silica gel (Chiralcel 0J ${ }^{\circledR}$ ) stationary phase

\begin{tabular}{cccc}
\hline Name & Mobile Phase & Ref. \\
\hline $\begin{array}{c}\text { Dia-(1S3R,1R3R)-3-benzyl- } \\
\text { oxymethyl-1,3-dihydro- } \\
\text { isobenzofuran-1-thymine }\end{array}$
\end{tabular}




\begin{tabular}{|c|c|c|c|}
\hline Name & Structure & Mobile Phase & Ref. \\
\hline 2-Benzyl-indan-1-one & & 90:10 hexane / 2-propanol & [269] \\
\hline Disopyramide & & $73: 27 \mathrm{CO}_{2} /$ ethanol (SFC*) & [270] \\
\hline Mepivacaine & & $\begin{array}{l}\text { 85:15:0.1 isohexane / } \\
\text { ethanol or 2-propanol / } \\
\text { diethylamine }\end{array}$ & {$[271]$} \\
\hline $\begin{array}{l}\text { 2,2-Dimethyl-3-(2-methyl- } \\
\text { propenyl)-cyclopropane- } \\
\text { carboxylic acid }\end{array}$ & & 90:10 hexane / 2-propanol & {$[272]$} \\
\hline
\end{tabular}

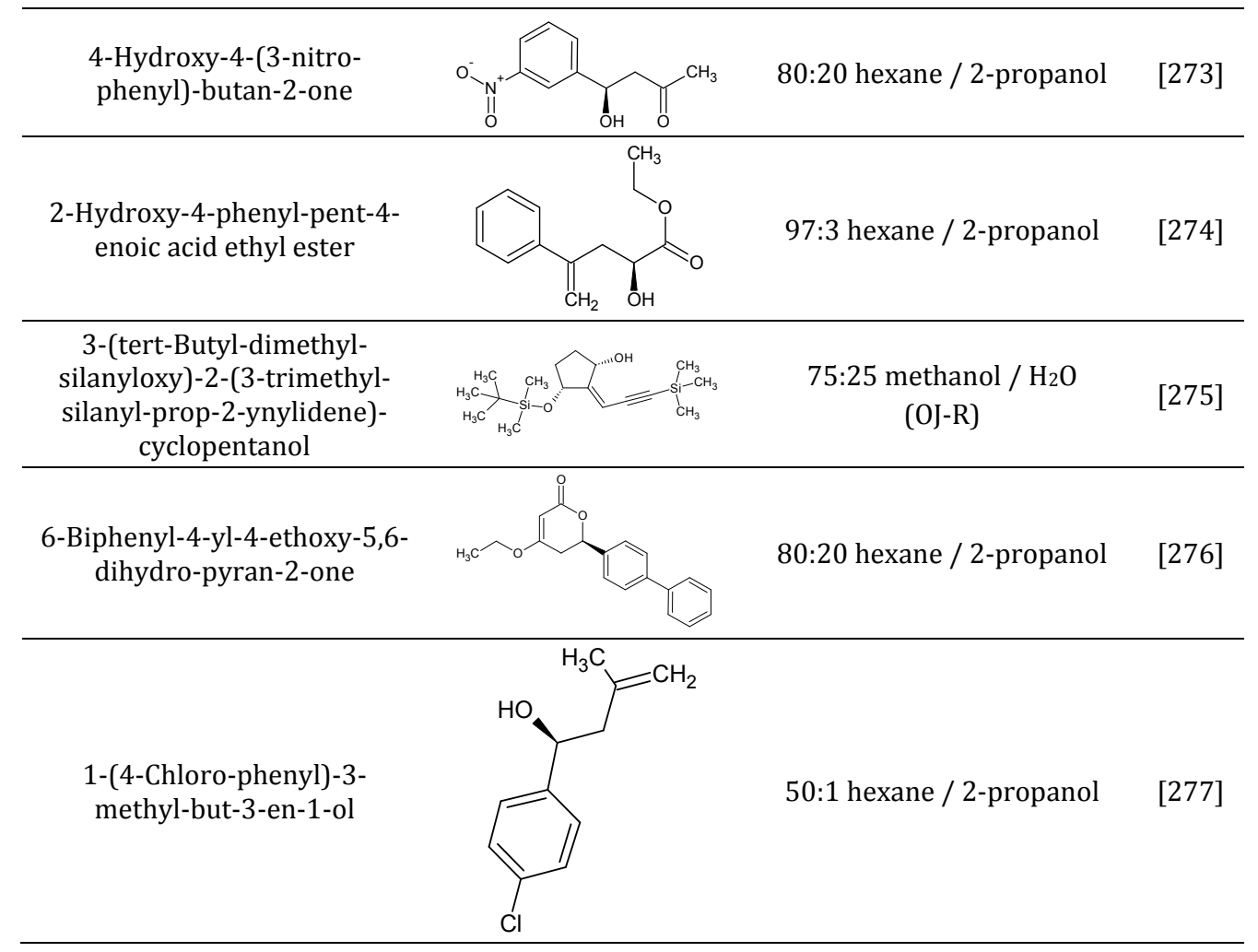




\begin{tabular}{|c|c|c|c|}
\hline Name & Structure & Mobile Phase & Ref. \\
\hline $\begin{array}{l}\text { 3-Benzylsulphanyl-pentan-1- } \\
\text { ol }\end{array}$ & & 96:4 hexane / 2-propanol & [278] \\
\hline 4-Methyl-N-(1-phenyl-ethyl)- & & 70:30 hexane / 2-propanol & [279] \\
\hline $\begin{array}{l}\text { 3-[Hydroxy-(4-nitro-phenyl)- } \\
\text { methyl]-but-3-en-2-one }\end{array}$ & & 96:4 hexane / 2-propanol & [280] \\
\hline $\begin{array}{l}\text { 2-(3-0xo-1,3-diphenyl- } \\
\text { propyl)-malonic acid dibenzyl } \\
\text { ester }\end{array}$ & & 90:10 hexane / 2-propanol & [281] \\
\hline $\begin{array}{l}\text { 1-(4-Chloro-phenyl)-3- } \\
\text { methyl-but-3-en-1-ol }\end{array}$ & & 50:1 hexane / 2-propanol & [282] \\
\hline $\begin{array}{l}\text { 1-Ethynyl-4-methyl-2-oxo- } \\
\text { cyclohex-3-enecarboxylic acid } \\
\text { tert-butyl ester }\end{array}$ & & 90:10 hexane / 2-propanol & [283] \\
\hline $\begin{array}{l}\text { 1,2,3,4-Tetrahydro- } 2,2,4,7- \\
\text { tetramethylquinoline }\end{array}$ & & $70: 30 \mathrm{CO}_{2}$ / ethanol (SFC*) & [284] \\
\hline
\end{tabular}




\begin{tabular}{|c|c|c|c|}
\hline Name & Structure & Mobile Phase & Ref. \\
\hline $\begin{array}{l}\text { 3-(4-Nitro-phenyl)-5-phenyl- } \\
\text { 4,5-dihydro-isoxazole }\end{array}$ & & 100 methanol & [285] \\
\hline 10-Hydroxycamptothecin & & 100 methanol & [286] \\
\hline $\begin{array}{c}\text { Acetic acid 3-tert- } \\
\text { butoxycarbonylamino-7,9- } \\
\text { dichloro-8-oxo-1-oxa- } \\
\text { spiro[4.5]deca-6,9-dien-2-yl } \\
\text { ester }\end{array}$ & & 90:10 hexane / ethanol & [287] \\
\hline $\begin{array}{l}\text { Anti-bicyclo[3.3.1]nonane- } \\
\text { 3,7-dione dioxime }\end{array}$ & & 99:1 hexane / 2-propanol & [288] \\
\hline $\begin{array}{l}\text { 3-(4-Chloro-phenyl)-1- } \\
\text { phenyl-pent-4-yn-1-one }\end{array}$ & & 85:15 hexane / 2-propanol & [289] \\
\hline $\begin{array}{l}\text { 2-Ethylhexyl 3-[(2-[[2- } \\
\text { phenylpropanoyl]amino]phe } \\
\text { nyl)sulphanyl]propanoate }\end{array}$ & & $\begin{array}{l}\mathrm{H}_{2} \mathrm{O} / \text { acetonitrile (gradient } \\
40: 60 \text { to } 0: 90 \text { in } 30 \mathrm{~min} \text { ) }\end{array}$ & [290] \\
\hline $\begin{array}{l}\text { 2-[2-Hydroxypropyl]-1H- } \\
\text { isoindole-1,3(2H)-dione }\end{array}$ & & Not reported & [291] \\
\hline $\begin{array}{c}\text { (RR,SS)-2-(4- } \\
\text { Benzylpiperazin-1-yl)-1-(5- } \\
\text { chloro-6- } \\
\text { methoxynaphthalen-2- } \\
\text { yl)propan-1-ol }\end{array}$ & & $\begin{array}{l}\text { 80:20:0.1 hexane / 2- } \\
\text { propanol / diethylamine }\end{array}$ & [292] \\
\hline
\end{tabular}

*SFC - supercritical fluid chromatography 
Table 6.13. Conditions for chiral separations of selected compounds using cellulose triphenylcarbamate coated on silica (Chiralcel $\mathrm{OC}^{\circledR}$ ) stationary phase

Name
$\begin{gathered}\text { 3-(3-Hydroxy-1-isopropyl- } \\ \text { 2,2-dimethyl-4-oxo-azetidin- } \\ \text { 3-yl)-benzoic acid methyl } \\ \text { ester }\end{gathered}$
$\begin{aligned} & \text { 4-(3-Methyl-2-oxo- } \\ & \text { tetrahydro-furan-3-yl)- } \\ & \text { benzoic acid ethyl ester }\end{aligned}$

3-Hydroxy-1,3,4,5tetrahydro-benzo[b]azepin-2one

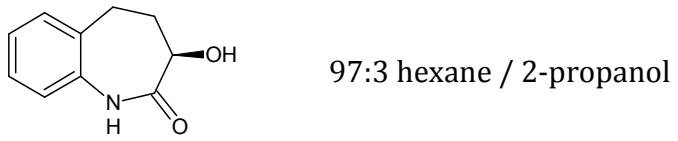

4-Methyl-3,6-dioxabicyclo[3.1.0]hexan-2-one<smiles>C[C@@H]1OC(=O)C2OC21</smiles>

10:1 hexane / 2-propanol

3-Allyl-2-butyl-4-methyl-1[(4-methylphenyl)sulphonyl]2,5-dihydro-1H-pyrrole

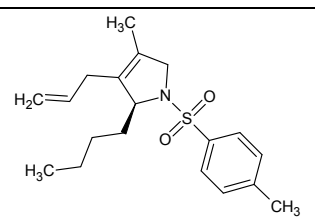

97:3 hexane / 2-propanol

2-tert-Butoxycarbonylamino-

3-thiazol-4-yl-propionic acid<smiles>N[C@@H](Cc1cscn1)C(=O)O</smiles>

5-[2-[2-(2-Ethoxy-phenoxy)-
ethylamino]-propyl]-2-
methoxy-benzenesulphon-
amide, Tamsulosin




\begin{tabular}{|c|c|c|c|}
\hline Name & Structure & Mobile Phase & Ref. \\
\hline $\begin{array}{l}\text { di-0,0-(p-Toluyl)- } D \text {-tartaric } \\
\text { acid }\end{array}$ & & 90:10 hexane / 2-propanol & [302] \\
\hline $\begin{array}{l}\text { [3a,4-Dimethyl-hexahydro- } \\
\text { benzofuran-( } 2 E) \text {-ylidene]- } \\
\text { acetic acid isopropyl ester }\end{array}$ & & 30:1 hexane / ethanol & [303] \\
\hline $\begin{array}{l}\text { 2,6-Diethoxy-1,5-dimethyl- } \\
\text { 2,6-diphenyl-3,7-dioxa-bi- } \\
\text { cyclo[3.3.1]nonane }\end{array}$ & & $100 \%$ hexane & [304] \\
\hline $\begin{array}{l}\text { 2-(tert-Butyl-dimethyl-silany- } \\
\text { loxy)-2-(2-nitro-phenyl)- } \\
\text { pent-4-enal }\end{array}$ & & 99:1 heptane / 2-propanol & [305] \\
\hline $\begin{array}{l}\text { 1-Cyclohexenyl-1-oxopent-4- } \\
\text { en-2-yl acetate }\end{array}$ & & 99:1 heptane / 2-propanol & [306] \\
\hline $\begin{array}{c}\text { Pilocarpine, 3-Ethyl-4-(3- } \\
\text { methyl-3H-imidazol-4- } \\
\text { ylmethyl)-dihydro-furan-2- } \\
\text { one }\end{array}$ & & 30:70 hexanes / ethanol & [307] \\
\hline
\end{tabular}




\begin{tabular}{ccc}
\hline Name & Mobile Phase & Ref. \\
2,2,2-Trifluoro- $\mathrm{N}$-[2-hydroxy- \\
1-phenylethyl]acetamide
\end{tabular}

Table 6.14. Conditions for chiral separations of selected compounds using cellulose tris(4-Methyl-phenylcarbamate)coated on silica (Chiralcel OG $^{\circledR}$ ) stationary phase

\begin{tabular}{|c|c|c|c|}
\hline Name & Structure & Mobile Phase & Ref. \\
\hline $\begin{array}{l}\mathrm{N}-(2-\text {-Hydroxy-1-phenyl- } \\
\text { ethyl)-4-methyl- } \\
\text { benzenesulphonamide }\end{array}$ & & 70:30 hexane / 2-propanol & {$[310]$} \\
\hline 3-Phenyl-cyclopentanol & & 90:10 hexane / 2-propanol & [311] \\
\hline $\begin{array}{l}\text { 2-Acetylamino-2-(5- } \\
\text { trimethylsilanyl-penta-2,3- } \\
\text { dienyl)-malonic acid diethyl } \\
\text { ester }\end{array}$ & & 98:2 hexane / 2-propanol & [312] \\
\hline $\begin{array}{c}\text { 2-Methyl-1,2,3,4,9,13b- } \\
\text { hexahydro-2,4a,5-triaza- } \\
\text { tribenzo[a,c,e]cycloheptene }\end{array}$ & & $\begin{array}{c}\text { 98:2:0.1 hexane / ethanol / } \\
\text { diethylamine }\end{array}$ & [313] \\
\hline$Z$-ketoxime derivative & & 50:1 hexane / 2-propanol & [314] \\
\hline
\end{tabular}




\begin{tabular}{|c|c|c|c|}
\hline Name & Structure & Mobile Phase & Ref. \\
\hline Ethaboxam & & 70:30 hexane / ethanol & [315] \\
\hline $\begin{array}{l}\text { 4-Phenyl-tetrahydro-pyran-2- } \\
\text { one }\end{array}$ & & 90:10 hexane / 2-propanol & [316] \\
\hline Metaproterenol & & $\begin{array}{c}90: 10 \text { hexane / ethanol / } \\
0.2 \% \text { butylamine }\end{array}$ & [301] \\
\hline $\begin{array}{l}\text { Butyric acid 2'-hydroxy- } \\
{[1,1 \text { ']binaphthalenyl-2-yl }} \\
\text { ester }\end{array}$ & & 15:1 hexane / 2-propanol & [317] \\
\hline $\begin{array}{c}\text { 19-Methyl-6,7,9,10- } \\
\text { tetrahydro- } \\
\text { dibenzo[b,g][1,3]thiazolo[3,2- } \\
\text { d] }[1,9,12,4,6] \text { trioxadiazacyclo } \\
\text { tetradecine }\end{array}$ & & 60:40 hexane / 2-propanol & [308] \\
\hline $\begin{array}{l}\text { Diisopropyl 1-(3-benzyl-5- } \\
\text { chloro-2-oxoindolin-3-yl) } \\
\text { hydrazine-1,2-dicarboxylate }\end{array}$ & & 90:10 hexane / 2-propanol & [318] \\
\hline $\begin{array}{l}\text { 2,6-Dimethylphenyl 3-(1,3- } \\
\text { benzodioxol-5-yl)-3-(1,3-di- } \\
\text { oxo-1,3-dihydro-2H-isoindol- } \\
\text { 2-yl)propanoate }\end{array}$ & & 90:10 hexane / 2-propanol & [319] \\
\hline $\begin{array}{l}\text { 2,6-Dimethylphenyl (3R)-3- } \\
\text { (3,5-dimethylphenyl)-3-(1,3- } \\
\text { dioxo-1,3-dihydro-2H- } \\
\text { isoindol-2-yl)propanoate }\end{array}$ & & 90:10 hexane / 2-propanol & [319] \\
\hline
\end{tabular}


Table 6.15. Conditions for chiral separations of selected compounds using cellulose tris(4-Chloro-phenylcarbamate) coated on silica (Chiralcel $\mathrm{OF}^{\circledR}$ ) stationary phase

\begin{tabular}{|c|c|c|c|}
\hline Name & Structure & Mobile Phase & Ref. \\
\hline Econazole & & $\begin{array}{l}\text { 425:74:1 hexane / 2- } \\
\text { propanol / diethylamine }\end{array}$ & [320] \\
\hline $\begin{array}{l}\text { 3-Methyl-1-(2-oxo-3-phenyl- } \\
\text { tetrahydro-pyran-4- } \\
\text { ylmethyl)-piperidine-3- } \\
\text { carboxylic acid ethyl ester }\end{array}$ & & $\begin{array}{c}\text { Gradient } 96: 4 \mathrm{CO}_{2} / \\
\text { methanol to } 60: 40 \mathrm{CO}_{2} / \\
\text { methanol (SFC*) }\end{array}$ & [321] \\
\hline $\begin{array}{l}\text { 2-Acetyl-4,4-dimethyl-2-(3- } \\
\text { phenyl-allyl)-cyclohexanone }\end{array}$ & & 96:4 hexane / 2-propanol & [322] \\
\hline $\begin{array}{c}\text { 6-Bromo-7,8-dihydro- } \\
\text { benzo[def]chrysene-7,8-diol }\end{array}$ & & 50:50 hexane / 2-propanol & [323] \\
\hline $\begin{array}{l}\text { 3-Benzyloxymethyl-5- } \\
\text { hydroxy-2-phenyl-1- } \\
\text { pyrrolidin-1-yl-pentan-1-one }\end{array}$ & & $\begin{array}{c}\text { Gradient } 96: 4 \mathrm{CO}_{2} / \\
\text { methanol to } 60: 40 \mathrm{CO}_{2} / \\
\text { methanol }\left(\mathrm{SFC}^{*}\right)\end{array}$ & [324] \\
\hline $\begin{array}{l}\text { 2-(1-Methyl-1H-indol-3-yl)- } \\
\text { 1,2-diphenyl-ethanol }\end{array}$ & & 91:9 hexane / 2-propanol & [325] \\
\hline $\begin{array}{l}\text { 3-(2-Nitro-1-p-tolyl-ethyl)-2- } \\
\text { phenyl-1H-indole }\end{array}$ & & $85: 15$ hexane / 2-propanol & [326] \\
\hline
\end{tabular}




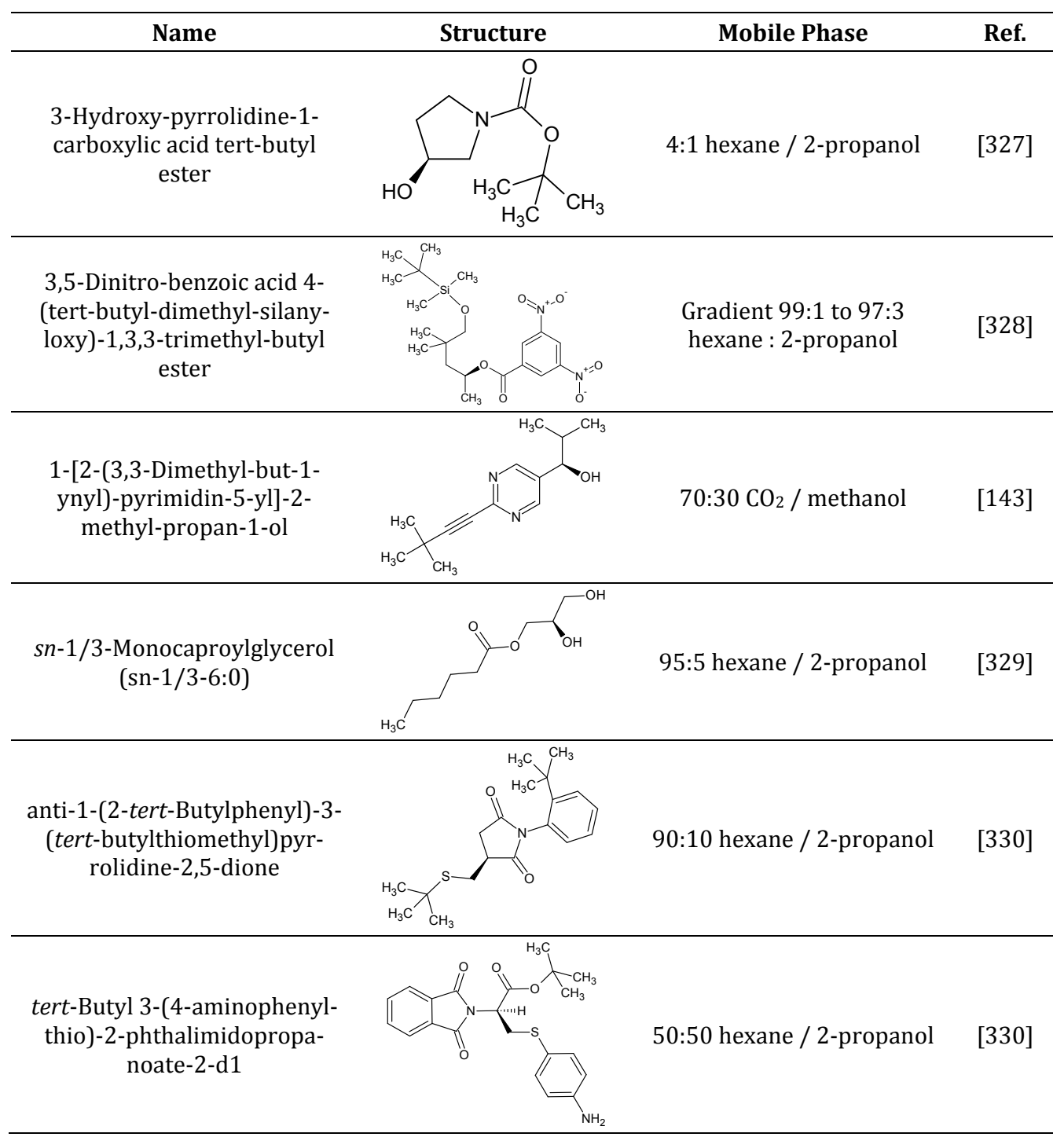

* SFC - supercritical fluid chromatography 
Table 6.16. Conditions for chiral separations of selected compounds using cellulose tribenzoate coated on macroporous silica(Chiralcel OB/OB- ${ }^{\circledR}$ ) stationary phase

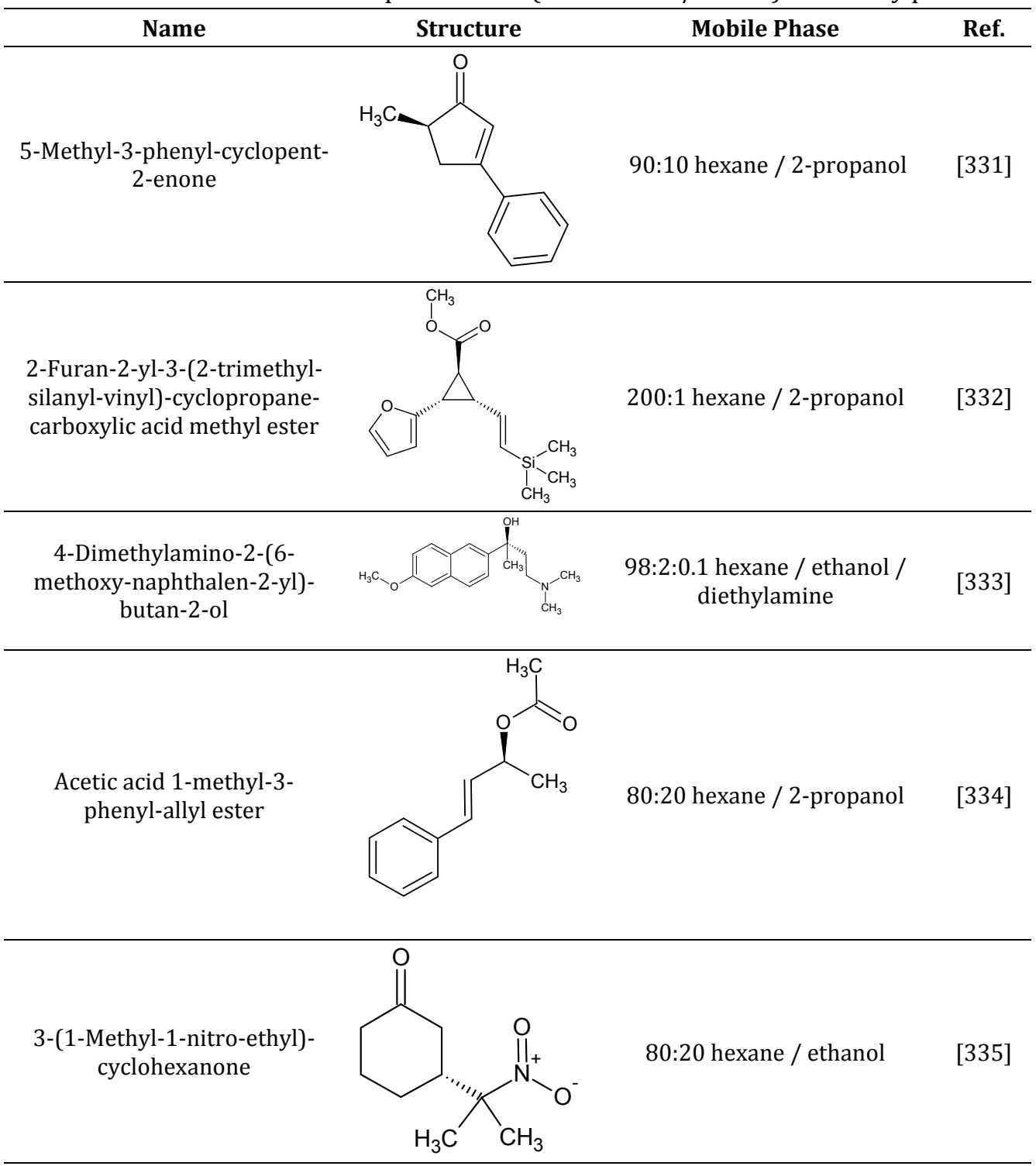

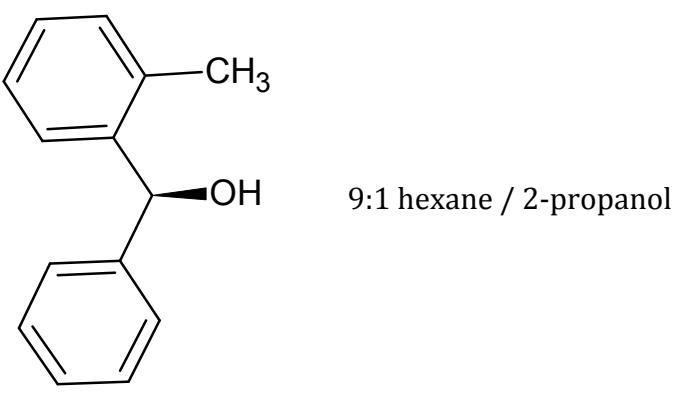




\begin{tabular}{cccc}
\hline Name & Mobile Phase & Ref. \\
\hline 2-Methanesulphinyl-pyridine & & \\
1,2-Di-thiophen-2-yl-ethane- \\
1,2-diol
\end{tabular}

$\left.\begin{array}{l}\text { 2-Methyl-1-phenyl-propan-1- } \\ \text { [3enzoic acid 1-methyl-butyl } \\ \text { ester }\end{array}\right]$ [327]




\begin{tabular}{cccc}
\hline Name & Mobile Phase & Ref. \\
\hline $\begin{array}{c}\text { tert- } \\
\text { putyl(dimethylamino)phenyl }\end{array}$ [-Chloro-phenyl)-trimethyl- \\
silanyloxy-acetonitrile
\end{tabular}

2-Hydroxy-1,4-diphenylpent-4-en-1-one

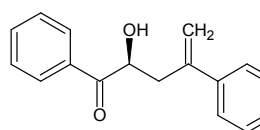

97:3 hexane / 2-propanol

1-[2-(3,3-Dimethyl-but-1-
$\begin{aligned} & \text { ynyl)-pyrimidin-5-yl]-2- } \\ & \text { methyl-propan-1-ol }\end{aligned}$
$\begin{aligned} & \text { 4-(Methanesulphinyl)-2- } \\ & \text { methyl-benzene } \\ & \text { tetrahydro-naphthalen-2-yl)- } \\ & \text { benzonitrile }\end{aligned}$
[348]
[34]
2-(Cyclopentyl-hydroxy-



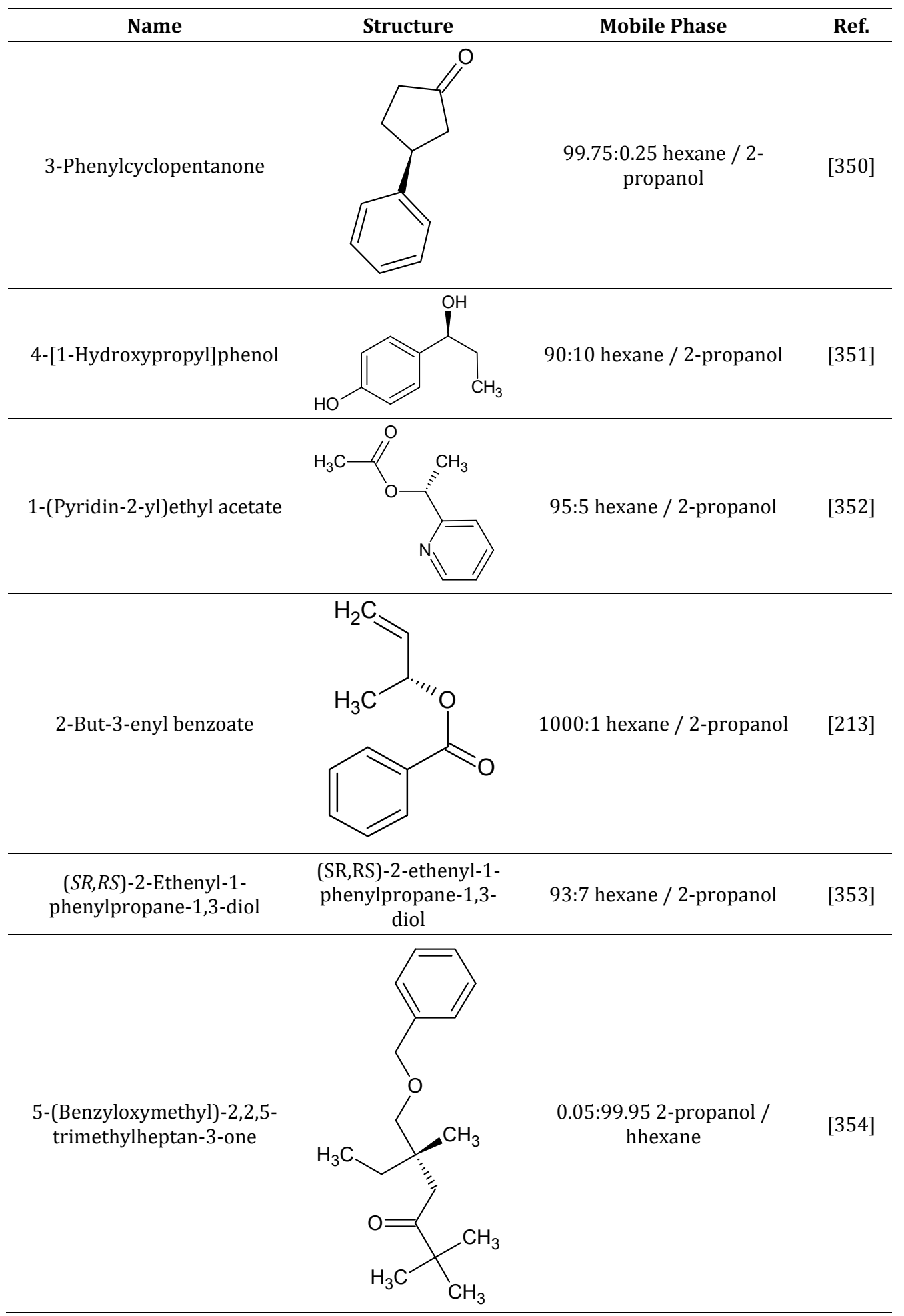

*SFC - supercritical fluid chromatography 
Table 6.17. Conditions for chiral separations of selected compounds using cellulose tricinnamate coated on silica gel (Chiralcel $\mathrm{OK}^{\circledR}$ ) stationary phase

\begin{tabular}{|c|c|c|c|}
\hline Name & Structure & Mobile Phase & Ref. \\
\hline Econazole & & $\begin{array}{c}\text { 425:74:1 hexane / 2-propanol } \\
\text { / diethylamine }\end{array}$ & [320] \\
\hline Miconazole & & $\begin{array}{c}\text { 425:74:1 hexane / 2-propanol } \\
\text { / diethylamine }\end{array}$ & [320] \\
\hline Sulconazole & & $\begin{array}{c}\text { 425:74:1 hexane / 2-propanol } \\
\text { / diethylamine }\end{array}$ & {$[320]$} \\
\hline $\begin{array}{c}\text { 2-Phenyl-4,5-dihydro- } \\
\text { oxazole-4-carboxylic acid } \\
\text { methyl ester }\end{array}$ & & 90:10 hexane / 2-propanol & [355] \\
\hline
\end{tabular}

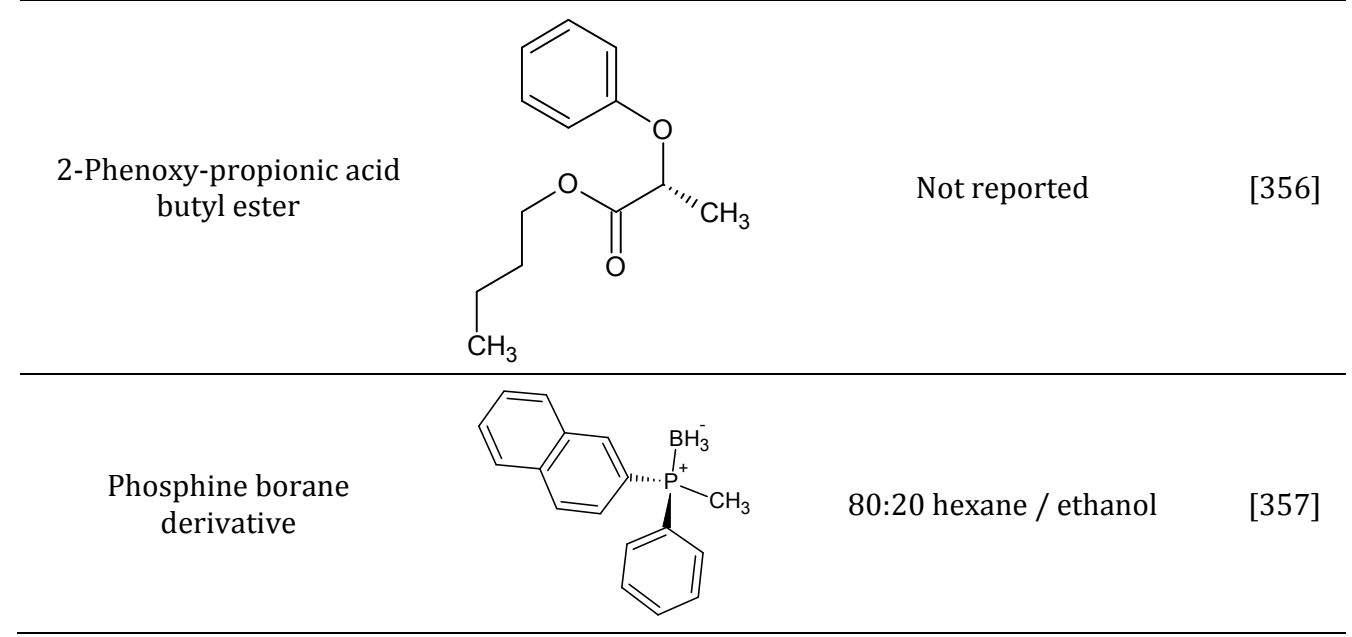




Name
$\begin{gathered}\text { 2-[(3-Chloro-phenyl)- } \\ \text { hydroxy-methyl]-acrylic } \\ \text { acid }\end{gathered}$

Table 6.18. Conditions for chiral separations of selected compounds using cellulose tris(3,5-dichlorophenylcarbamate) photochemically immobilised on silica (Chiralpak IC ${ }^{\circledR}$ ) stationary phase

\begin{tabular}{lll}
\hline Name & Mobile Phase & Ref. \\
\hline $\begin{array}{l}\text { 3-(Dimethoxymethyl)-6- } \\
\text { methoxy-2-(4-nitrophe- } \\
\text { nyl)tetrahydro-2H-pyran }\end{array}$
\end{tabular}




Name

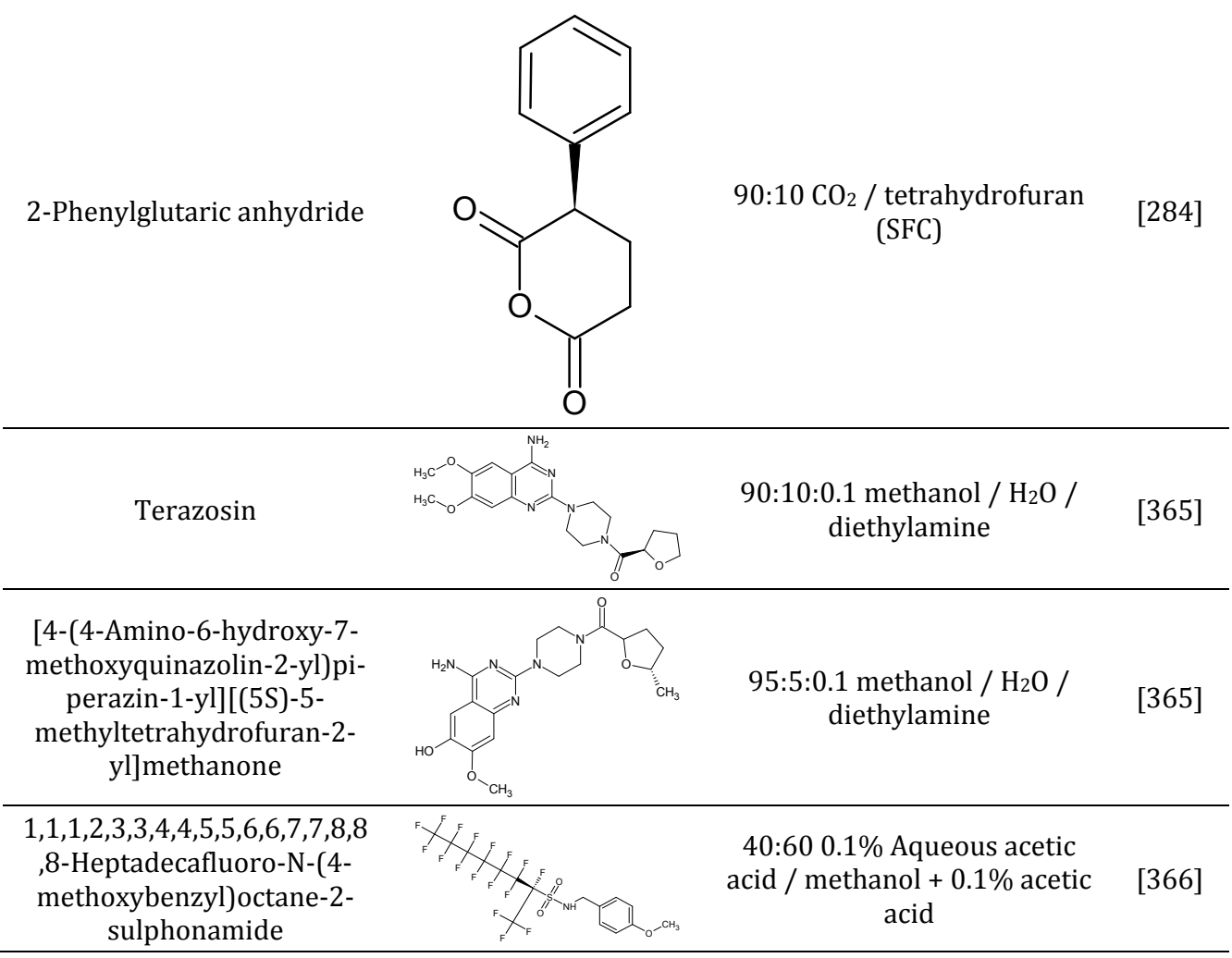




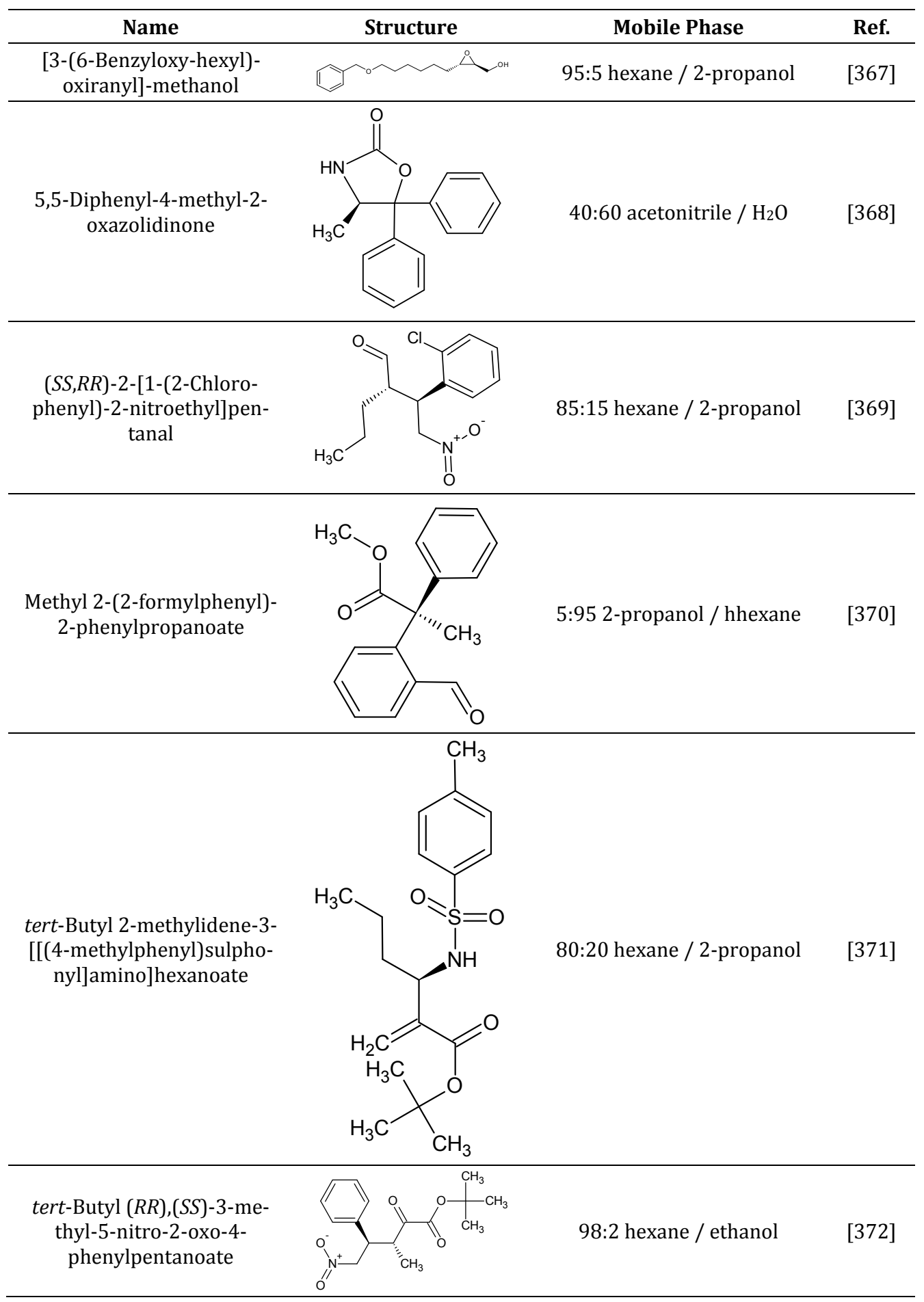


Table 6.19. Conditions for chiral separations of selected compounds using amylose tris[(S)alpha-phenethyl]carbamate coated on silica gel (Chiralpak $A S^{\circledR}$ ) stationary phase

Name Structure
$\begin{gathered}\text { Dia-(1S3R,1R3R)-3-benzyl- } \\ \text { oxymethyl-1,3-dihydro-iso- } \\ \text { benzofuran-1-thymine }\end{gathered}$
$\begin{gathered}\text { Dia-(1R3R,1S3R)-3-benzyl- } \\ \text { oxymethyl-1,3-dihydro-iso- } \\ \text { benzofuran-1-uracil }\end{gathered}$
benzyl ester

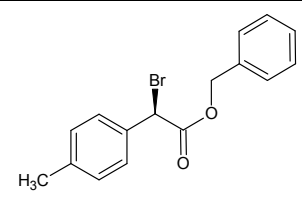

99.8:0.2 hexane / 2-propanol

2-(3-Bromo-phenyl)-oxirane<smiles>Brc1cccc(C2CO2)c1</smiles>

90:10 hexane / 2-propanol

6-Methyl-5-(N-phenylaminooxy)-hept-3-en-2-one<smiles>CC(=O)/C=C/C(ONc1ccccc1)C(C)C</smiles>

98:2 hexane / 2-propanol

3-(4-Cyanophenyl)-2,3epoxy-1-phenylpropanone

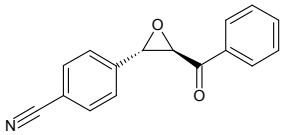

9:1 hexane / 2-propanol

2-(1-Hydroxy-propyl)- $\begin{gathered}\text { [377] } \\ \text { cyclohex-2-enone }\end{gathered}$




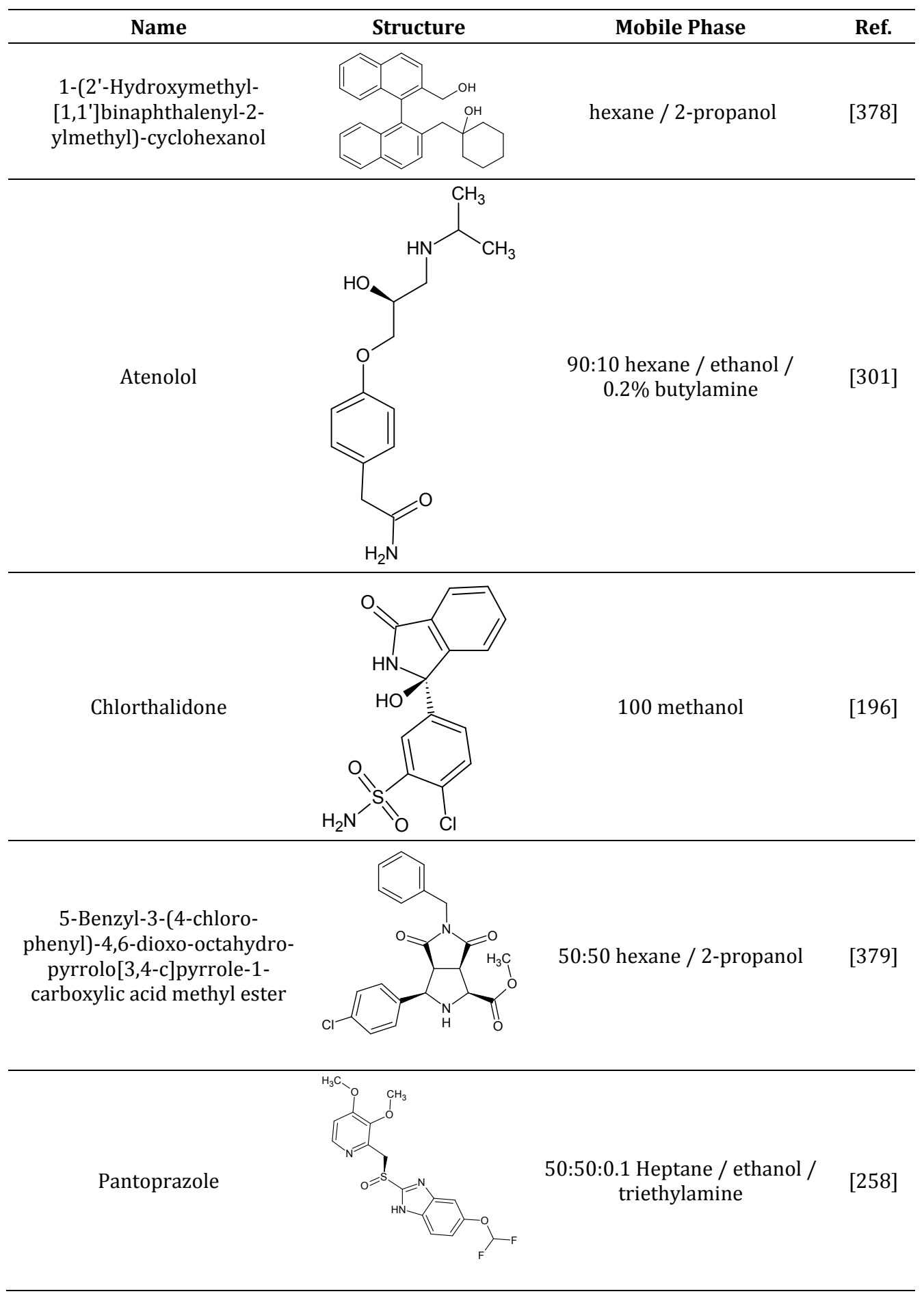




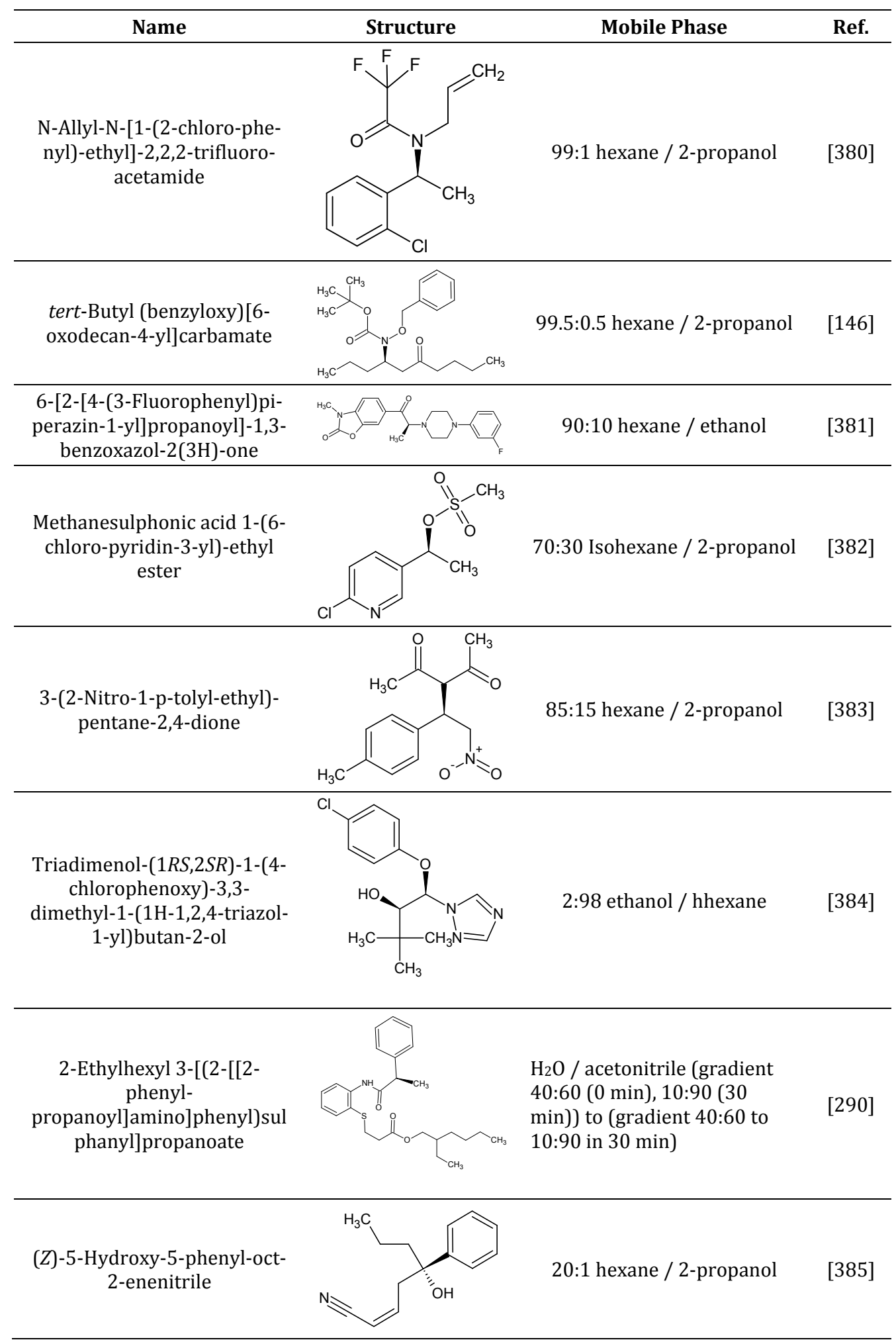




\subsubsection{Antibiotic Phases}

The glycopeptide macrocycle antibiotics are classes of compounds with highly enantioselective properties. They include vancomycin, teicoplanin and ristocetin A [386]. Such high enantioselective properties are due to their amphoteric character, their molecular structure (which in solution accentuates enantioselective interactions) and their hydrophilic and hydrophobic functional groups (which makes them soluble in aqueous and organic solvents) [387]. Such properties make them amenable for use as chiral selectors in either capillary electrophoresis or HPLC (Tables 6.20-6.22). There have been over a hundred different glycopeptide antibiotics identified in the fermentation broth of various bacteria. All have a heptapeptide core of seven amino acid residues with a covalently joined side chain and sugar substituents at various positions. In this classification scheme, vancomycin and eremomycin are assigned to group I. Groups II and III include compounds such as avoparcin, ristocetin and teicoplanin, which have aromatic residues at different positions in the molecule [388]. They possess multiple stereogenic centres and can interact with a solute through hydrogen bonding, dipole-dipole interactions, $\pi-\pi$ interactions, hydrophobic interactions, electrostatic interactions and sterically-based interactions. Due to the multiple interactions that they can exhibit, these macrocyclic antibiotics have been immobilised on a silica matrix and used as chiral stationary phases. These columns show very good selectivity toward a large class of compounds [389]. They operate in different modes: normal phase, polar organic and sub/supercritical modes [125,389]. In reversed phase mode, the mobile phase should be buffered in the range of pH between 4 and 7 . Electrostatic and hydrophobic interactions are the main types of interactions responsible for the enantiomeric separation on these phases.

Table 6.20. Mobile phase compositions for enantiomeric separation of selected compounds on Vancomycin bonded to silica (Chirobiotic $\mathrm{V}^{\circledR}$ ) stationary phase

\begin{tabular}{|c|c|c|c|}
\hline Name & Structure & Mobile Phase & Ref. \\
\hline N-CBZ-Phenylalanine & & $\begin{array}{c}90: 101 \% \\
\text { triethylammonium acetate, } \\
\text { pH } 4.1 \text { / acetonitrile }\end{array}$ & [184] \\
\hline Nisoldipine & & $\begin{array}{l}50: 50 \text { triethylammonium } \\
\text { acetate buffer / methanol }\end{array}$ & [390] \\
\hline
\end{tabular}




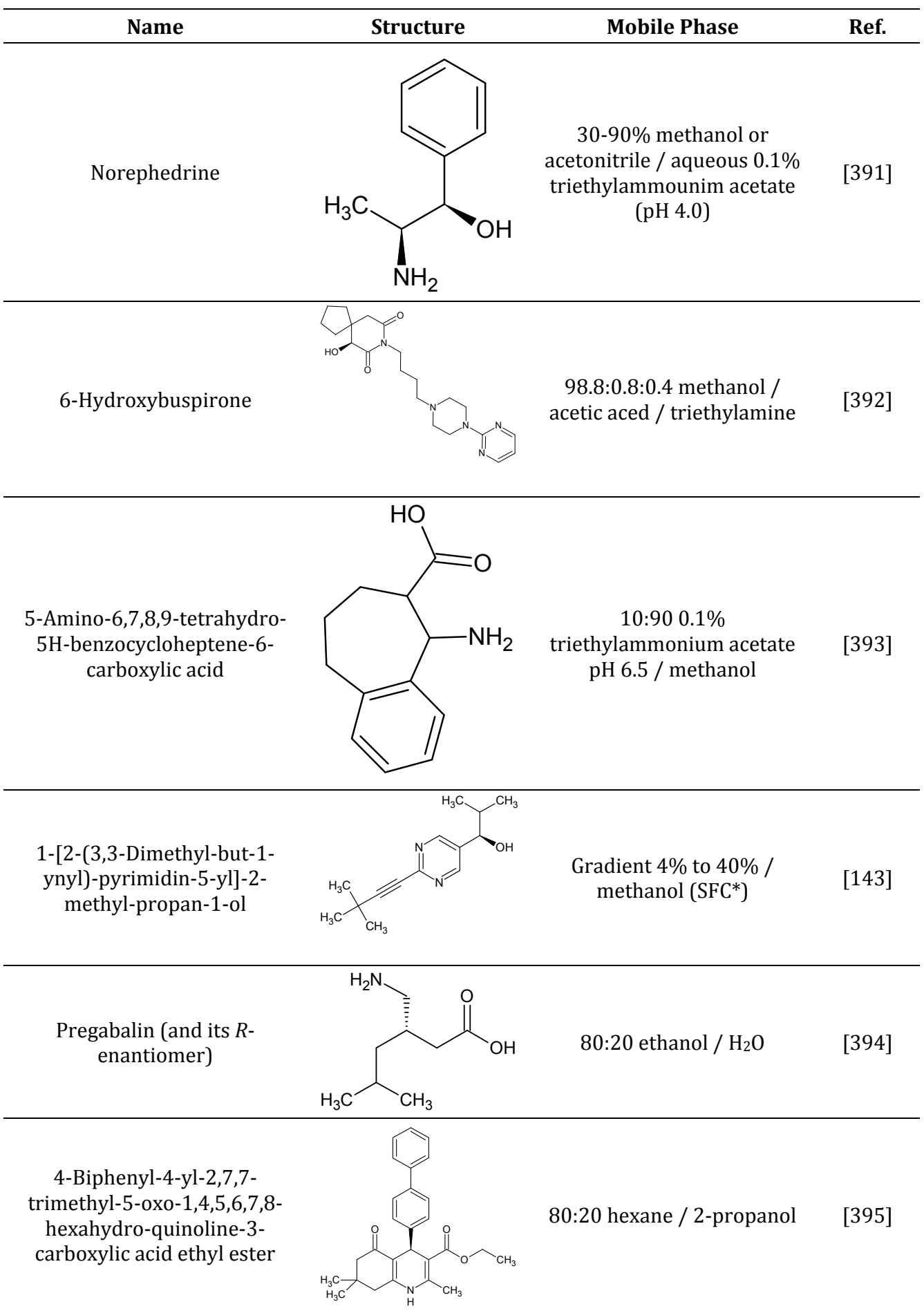

* SFC - supercritical fluid chromatography 
Table 6.21. Mobile phase compositions for enantiomeric separation of selected compounds on Amphoteric teicoplanin covalently bonded to silica (Chirobiotic $\mathrm{T}^{\circledR}$ ) stationary phase

\begin{tabular}{|c|c|c|c|}
\hline Name & Structure & Mobile Phase & Ref. \\
\hline N-CBZ-Phenylalanine & & $\begin{array}{l}\text { 80:20 Triethylammonium } \\
\text { acetate } \mathrm{pH} 4.1 \text { / methanol }\end{array}$ & [184] \\
\hline $\begin{array}{l}\text { 5,9-Dimethyl-2-(2-methyl- } \\
\text { propenyl)-2,3-dihydro- } \\
\text { furo[3,2-g]chromen-7-one }\end{array}$ & & 95:5 $\mathrm{CO}_{2}$ / methanol (SFC*) & [396] \\
\hline $\begin{array}{l}\text { 2-Amino-3-(4- } \\
\text { trifluoromethyl-phenyl)- } \\
\text { propionic acid }\end{array}$ & & $70: 30$ methanol $/ \mathrm{H}_{2} \mathrm{O}$ & [397] \\
\hline $\begin{array}{l}\text { 2-Aminomethyl-3-(3,4- } \\
\text { dihydroxy-phenyl)-propionic } \\
\text { acid }\end{array}$ & & $70: 30$ methanol $/ \mathrm{H}_{2} \mathrm{O}$ & [398] \\
\hline Tyrosine & & $\begin{array}{l}20: 80 \mathrm{H}_{2} \mathrm{O}(0.2 \% \\
\text { triethylammounium acetate, } \\
\text { pH 3.8) / methanol }\end{array}$ & [399] \\
\hline $\begin{array}{c}\text { 2-[4-(1,3-Dioxo-1,3-dihydro- } \\
\text { isoindol-2-yl)-3-oxo-1,3,4,5- } \\
\text { tetrahydro-benzo[c]azepin-2- } \\
\text { yl]-propionic acid }\end{array}$ & & $\begin{array}{l}\text { 100:0.1:0.1 methanol / } \\
\text { acetic acid / triethylamine }\end{array}$ & [400] \\
\hline $\begin{array}{l}\text { 3-Amino-4-methyl-pentanoic } \\
\text { acid }\end{array}$ & & $\begin{array}{l}\text { 70:30 methanol / 0.1\% } \\
\text { triethylammounium acetate } \\
\qquad(\mathrm{pH} 4.1)\end{array}$ & [401] \\
\hline
\end{tabular}




\begin{tabular}{|c|c|c|c|}
\hline Name & Structure & Mobile Phase & Ref. \\
\hline $\begin{array}{l}\text { 2-Aminomethylpentanoic } \\
\text { acid }\end{array}$ & & $\begin{array}{l}30: 700.1 \% \\
\text { triethylammonium acetate } \\
\text { (pH 4.1) / methanol }\end{array}$ & [402] \\
\hline Warfarin & & $80: 20$ heptane / ethanol & [403] \\
\hline
\end{tabular}

Table 6.22. Mobile phase compositions for enantiomeric separation of selected compounds on Ristocetin A covalently bonded to silica gel (Chirobiotic $\mathrm{R}^{\circledR}$ ) stationary phase

\begin{tabular}{cccc}
\hline Name & Mobile Phase & Ref. \\
\hline $\begin{array}{c}\text { 1,2,3,6-Tetrahydro-pyridine- } \\
\text { 2-carboxylic acid (baikaine) }\end{array}$ & & & \\
\end{tabular}

$\gamma$-phenyl- $\gamma$-butyrolactone<smiles>O=C1CC[C@H](c2ccccc2)O1</smiles>

95:5 hexane / ethanol

$\alpha$-benzyl-proline
$\begin{aligned} & \text { 6a,11a-Dihydro-6H-ben- } \\ & \text { zo[4,5]furo[3,2-c]chromene }\end{aligned}$




\begin{tabular}{|c|c|c|c|}
\hline Name & Structure & Mobile Phase & Ref. \\
\hline 3,4-Dihydroxyphenylalanine & & 1:1 methanol $/ \mathrm{H}_{2} \mathrm{O}$ & [406] \\
\hline $\begin{array}{l}\text { [(SS,RR)-4-(1,3-Dioxo-1,3- } \\
\text { dihydro-isoindol-2-yl)-5- } \\
\text { methyl-3-oxo-1,3,4,5-tetra- } \\
\text { hydro-benzo[c]azepin-2-yl]- } \\
\text { acetic acid }\end{array}$ & & $\begin{array}{l}\text { 100:0.01:0.01 methanol / } \\
\mathrm{CH}_{3} \mathrm{CO}_{2} \mathrm{H} / \text { triethylamine }\end{array}$ & [400] \\
\hline Camptothecin & & $\begin{array}{c}\text { 100:0.1:0.1 methanol / } \\
\mathrm{CH}_{3} \mathrm{CO}_{2} \mathrm{H} / \text { triethylamine }\end{array}$ & [286] \\
\hline $\begin{array}{c}(1 R S, 2 S R, 4 S R, 5 R S) \text {-2-Amino- } \\
\text { 4,5-dihydroxy-cyclohexane- } \\
\text { carboxylic acid }\end{array}$ & & $\begin{array}{c}20: 800.1 \% \text { Aqueous } \\
\text { triethylammonium acetate } \mathrm{pH} \\
\text { 4.1 / ethanol }\end{array}$ & [407] \\
\hline $\begin{array}{c}(1 S R, 2 R S, 3 S R)-2-\text { Amino-3- } \\
\text { hydroxy-cyclopentane- } \\
\text { carboxylic acid }\end{array}$ & & $\begin{array}{c}20: 800.1 \% \text { Aqueous } \\
\text { triethylammonium acetate } \mathrm{pH} \\
\text { 4.1 / ethanol }\end{array}$ & [407] \\
\hline
\end{tabular}

\subsubsection{Protein Phases}

Proteins are biopolymers consisting of amino acids linked together through peptide bonds arranged in a certain sequence. Molecular recognition in proteinligand complexes is responsible for the selective binding of a low molecular weight ligand to a specific protein which can be characterised by a binding constant. All these interactions are usually non-covalent in nature. The experimentally determined binding constants, $K_{\mathrm{i}}$, are typically in the range of $10^{-2}$ to $10^{-12} \mathrm{M}^{-1}$, which corresponds to a negative free energy of binding of 10 to $80 \mathrm{kJmol}^{-1}$ [408]. The interactions between ligands and proteins include a wide range of interactions including electrostatic, van der Waals, steric, hydrophobic and hydration forces [409] related to the active sites of the protein. The binding of a small molecule ligand to a protein requires shape and property complementarity. In the course of binding, the ligand and protein have to adapt to each other to achieve a successful recognition process. The small molecule ligand is usually the 
more flexible partner, and thus can adopt a large variety of different low energy conformations upon interaction with a protein [408]. The enantioselective recognition of molecules with one chiral centre requires a protein to interact with a minimum of three substrate locations, while stereoselectivity towards a substrate with two or three stereocentres requires interactions with a minimum of four or five substrate locations, respectively [410]. The inherent chirality of proteins makes them very good candidates for the separation of enantiomers. Proteins which can tolerate organic solvents, as well as high temperatures, and which can function over a wide $\mathrm{pH}$ range are useful as chiral stationary phases. Several proteins such as $\alpha_{1}$-acid glycoprotein (AGP) (Table 6.23), bovine serum albumin (BSA) (Table 6.24), human serum albumin (HSA), ovomucoid from chicken egg whites (OVM) (Table 6.25), avidin, cellobiohydrolase I (CBH I) (Table 6.26), pepsin, ovotransferrin and $\beta$-lactoglobulin have been immobilised on silica gel and successfully used as CSPs for enantiomeric separation [389]. Mobile phase optimisation with these CSPs is done through variations in $\mathrm{pH}$, ionic strength, temperature and organic modifiers. Enantioselectivity can be changed as a function of $\mathrm{pH}$. Increasing ionic strength increases hydrophobic interactions between the enantiomers and the CSP. The nature of the organic modifier also influences the enantioselectivity, as reversal of the elution order has been observed to be dependent upon the organic modifier used. Temperature also influences enantioselectivity; a decrease in temperature generally enhances enantioselectivity. Reversal of elution order has also been observed with a change in temperature. The protein CSPs have a broad range of applications and have been used for the separation of neutral, acidic and basic enantiomeric drugs [125].

Table 6.23. Mobile phase compositions for enantiomeric separation of selected compounds on $\alpha_{1}$-acid glycoprotein silica (Chiral-AGP ${ }^{\circledR}$ ) stationary phase

Name/Structure
$\begin{gathered}\text { 1-(2,2-Dimethyl-8,8a- } \\ \text { dihydro-3aH-indeno[1,2- } \\ \text { propan-1-one }\end{gathered}$
$\begin{aligned} & \text { (2-Phenyl-2,3-dihydro- } \\ & \text { benzofuran-3-yl)-methanol }\end{aligned}$
[25]




\begin{tabular}{|c|c|c|c|}
\hline Name/Structure & Structure & Mobile Phase & Ref. \\
\hline Bromoketamine & & $\begin{array}{c}\text { 94:610 mM ammonium } \\
\text { acetate buffer }(\mathrm{pH} 7.6) / 2- \\
\text { propanol }\end{array}$ & [413] \\
\hline $\begin{array}{l}\text { 5-Ethyl-1,2-dimethyl-4,4- } \\
\text { diphenyl-3,4-dihydro-2H- } \\
\text { pyrrolium }\end{array}$ & & $\begin{array}{l}\text { Gradient of methanol / } 20 \mathrm{mM} \\
\text { ammonium formate ( } \mathrm{pH} 5.7 \text { ) }\end{array}$ & [414] \\
\hline $\begin{array}{l}\text { Reboxetine, 2-[(2-Ethoxy- } \\
\text { phenoxy)-phenyl-methyl]- } \\
\text { morpholine }\end{array}$ & & $\begin{array}{c}\text { 12:88 acetonitrile / } \\
\text { phosphate buffer (pH 6) }\end{array}$ & [415] \\
\hline EDDP D3 & & $\begin{array}{l}\text { 82:18 ammonium acetate } \\
\text { buffer } 10 \mathrm{mM}(\mathrm{pH} \mathrm{7.0)} /\end{array}$ & [416] \\
\hline Ibuprofen & & $\begin{array}{c}\text { 990:10:0.2 phosphate buffer } \\
\text { (pH 6.9) / acetontrile / } \\
\text { dimethyloctylamine }\end{array}$ & [417] \\
\hline $\begin{array}{l}\text { tris(1,2-Dimethyl-3-indo- } \\
\text { lyl)phosphine oxide }\end{array}$ & & $\begin{array}{c}\text { 30:70 } \mathrm{CH}_{3} \mathrm{CN} / \text { phosphate } \\
\text { buffer (pH 4.6) }\end{array}$ & [418] \\
\hline
\end{tabular}




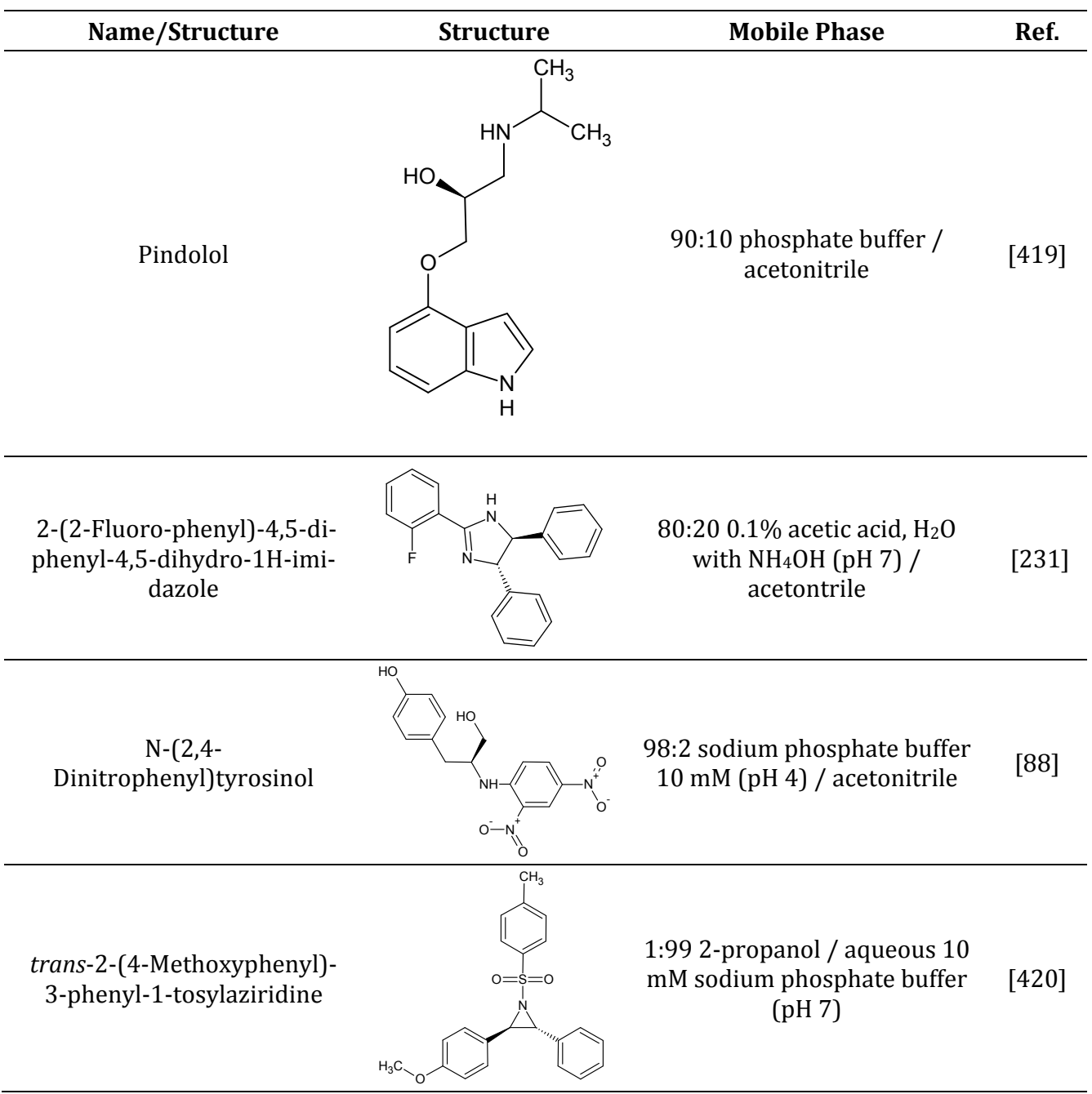

Table 6.24. Mobile phase compositions for enantiomeric separation of selected compounds on Bovine serum albumin (BSA) immobilised on silica gel (Chiral BSA-RP ${ }^{\circledR}$ ) stationary phase

\begin{tabular}{|c|c|c|c|}
\hline Name/Structure & Structure & Mobile Phase & Ref. \\
\hline \multicolumn{4}{|c|}{$\mathrm{CH}_{3}$} \\
\hline 2-Phenyl-pentanenitrile & & $\begin{array}{c}\text { 88:10:2 phosphate buffer (0.1 } \\
\text { M, pH 7.4) / acetonitrile/ 1- } \\
\text { butanol }\end{array}$ & {$[421]$} \\
\hline
\end{tabular}




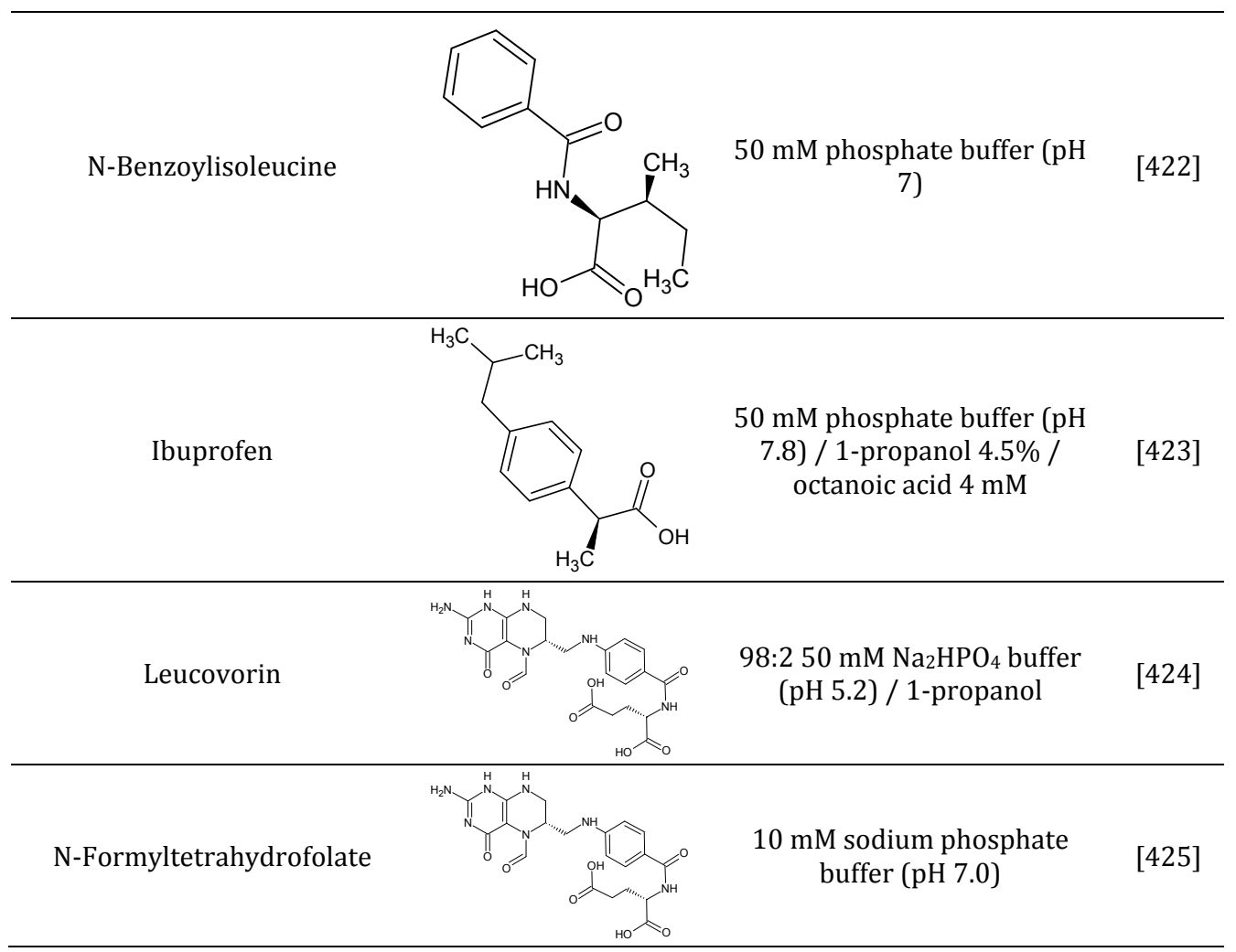

Table 6.25. Mobile phase compositions for enantiomeric separation of selected compounds on Ovomucoid protein immobilised to silica $\left(\mathrm{OVM}^{\circledR}\right)$ stationary phase

\begin{tabular}{|c|c|c|c|}
\hline Name/Structure & Structure & Mobile Phase & Ref. \\
\hline Ibuprofen & & $\begin{array}{l}\text { 90:10 } 20 \mathrm{mM} \text { phosphate } \\
\text { buffer (pH 5.1) / ethanol }\end{array}$ & [426] \\
\hline Benzoin & & $\begin{array}{l}\text { 90:10 } 20 \mathrm{mM} \text { phosphate } \\
\text { buffer (pH 5.1) / ethanol }\end{array}$ & [426] \\
\hline $\begin{array}{l}\text { NK-104 3-epimer and } \\
\text { enantiomer }\end{array}$ & & $\begin{array}{c}\text { 100:5:10 } 20 \mathrm{mM} \mathrm{KH}_{2} \mathrm{PO}_{4} \text { in } \\
\mathrm{H}_{2} \mathrm{O} / \text { acetonitrile / } \\
\text { methanol }\end{array}$ & [427] \\
\hline
\end{tabular}


Table 6.26. Mobile phase compositions for enantiomeric separation of selected compounds on Cellobiohydrolase (CBH I) immobilised onto silica (Chiral-CBH ${ }^{\circledR}$ ) stationary phase

\begin{tabular}{llll}
\hline Name/Structure & Mobile Phase & Ref. \\
0-Desethyl-reboxetine \\
methoxy-phenyl)-piperidine
\end{tabular}

\subsection{CONCLUSION}

The separation of enantiomers is a technique which is driven by the development of enantiomerically pure drugs. A large number of chiral stationary phases are available on the market, providing the opportunity to choose the right column for the separation of enantiomeric drugs. Understanding the interactions between these CSPs and enantiomeric analytes can provide a rationale for the development of an enantiomeric separation method.

\section{REFERENCES}

1. N. Grinberg. Chiral Separation in Pharmaceutical Industry. American Pharmaceutical Reviews 65 (2006) 12.

2. B. Feibush, N. Grinberg. The history of enantiomeric resolution. In Chromatographic Chiral separations, (Editors M. Zief, L.J. Crane) Marcel Dekker Inc., 1988, p. 1.

3. C.E. Dalgliesh. The optical resolution of aromatic amino acids on paper chromatograms, Journal of the Chemical Society (1952) 3940. 
4. S. Allenmark. Separation of enantiomers by protein-based chiral phases. In $A$ practical approach to chiral separations by liquid chromatography (Editor G. Subramanian) VCH Weinheim 1994, p. 183.

5. E. Gil-Av, B. Feibush, R. Charles-Sigler. Separation of enantiomers by gas chromatography with an optically active stationary phase. Tetrahedron Letters 7 (1966) 1009-1015.

6. W.H. Pirkle, T. Pochapsky. Theory and design of chiral stationary phases for direct chromatographic separation of enantiomers. In Packings and stationary phases in chromatographic techniques. (Editor K.K. Unger) Marcel Dekker, Inc., New York, 1990, p. 783.

7. B. Feibush. Chiral separation of enantiomers via selector/selectand hydrogen bondings. Chirality 10 (1998) 382-395.

8. S. Topiol. A general criterion for molecular recognition: Implications for chiral interactions. Chirality 1 (1989) 69-79.

9. G.J. Jeffrey. An introduction to hydrogen bonding. Oxford University Press, New York, 1997.

10. G. Zundel. Easily polarizable hydrogen bonds - their interactions with the environment - ir continuum and anomalous large proton conductivity. In The hydrogen bond. Recent developments in theory and experiments. II Structure and spectroscopy. Vol. II. (Eds. P. Schuster, G. Zundel, C. Sandorfy) North Holland Publishing Company, Amsterdam, 1976, p. 683.

11. T.E. Creighton. Proteins Structure and molecular properties, W. H. Freeman, New York, 1993.

12. N. Grinberg, T. Burakowski, A. M. Stalcup. Chrial separation. In HPLC for pharmaceutical scientists (Eds. Y. Kazakevich, R. Lobrutto) John Wiley \& Sons, Hoboken, New Jersy, 2007, p. 987,

13. B. Koppenhoefer, E. Bayer. Chiral recognition in the resolution of enantiomers by GLC. Chromatographia 19 (1984) 123-130.

14. B. Koppenhoefer, E. Bayer. Chiral recognition in gas cgromatographic analysis of enantiomers on chiral polysiloxanes. Journal of Chromatography Library 32 (1985) $1-42$.

15. Y. Dobashi, S. Hara. A chiral stationary phase derived from (R,R)-tartramide with broaden scope of application to the liquid chromatographic resolution of enantiomers. The Journal of Organic Chemistry 52 (1987) 2490-2496.

16. G. Blaschke. Chromatographic resolution of chiral drugs on polyamides and cellulose triacetate. Journal of Liquid Chromatography 9 (1986) 341-368.

17. G. Blaschke. Substituted polyacrylamides as chiral phases for the resolution of drugs. In Chromatographic chiral separation. (Eds. M. Zieff and L.J. Crane) Marcel Dekker, Inc., New York, 1988, p. 179.

18. I. Abe, K. Terada, T. Nakahara. Enantiomer separation of pharmaceuticals by capillary gas chromatography with novel chiral stationary phases. Biomedical Chromatography 14 (2000) 125-129.

19. G.P. Kaijser, J.H. Beijnen, A. Bult, H.J. Keizer, W.J.M. Underberg. Chromatographic analysis of the enantiomers of ifosfamide and some of its metabolites in plasma and urine. Journal of Chromatography B: Biomedical Sciences and Applications 690 (1997) 131-138. 
20. A.S.C. Chan, W. Hu, C.-C. Pai, C.-P. Lau, Y. Jiang, A. Mi, M. Yan, J. Sun, R. Lou, J. Deng. Novel Spiro Phosphinite Ligands and Their Application in Homogeneous Catalytic Hydrogenation Reactions. Journal of the American Chemical Society 119 (1997) 9570-9571.

21. I. Abe, N. Fujimoto, T. Nishiyama, K. Terada, T. Nakahara. Rapid analysis of amino acid enantiomers by chiral-phase capillary gas chromatography. Journal of Chromatography A 722 (1996) 221-227.

22. C.A. Bewley, H. He, D.H. Williams, D.J. Faulkner. Aciculitins A-C: Cytotoxic and Antifungal Cyclic Peptides from the Lithistid Sponge Aciculites oreintalis. Journal of the American Chemical Society 118 (1996) 4314-4321.

23. A. Berthod, E.Y. Zhou, K. Le, D.W. Armstrong. Determination and use of Rohrschneider-McReynolds constants for chiral stationary phases used in capillary gas chromatography. Analytical Chemistry 67 (1995) 849-857.

24. B. Koppenhoefer, U. Muehleck, K. Lohmiller. Backbone modification of Chirasil-Val: Effect of nonpolar side chains on enantiomer separation in gas chromatography. Chromatographia 40 (1995) 718-723.

25. L. Juhasz, L. Szilagyi, S. Antus, J. Visy, F. Zsila, M. Simonyi. New insight into the mechanism of hypervalent iodine oxidation of flavanone. Tetrahedron 58 (2002) 4261-4265.

26. M. Johannsen, S. Peper, A. Depta. Simulated moving bed chromatography with supercritical fluids for the resolution of bi-naphthol enantiomers and phytol isomers. Journal of Biochemical and Biophysical Methods 54 (2002) 85-102.

27. T. Raab, T. Hauck, A. Knecht, U. Schmitt, U. Holzgrabe, W. Schwab. Tautomerism of 4-hydroxy-2,5-dimethyl-3(2H) furanone: Evidence for its enentioselective biosyhntesis. Chirality 15 (2003) 573-578.

28. F. La Torre, R. Cirilli, R. Ferretti, B. Gallinella, R. Costi, R. Di Santo. Conversion of a racemic mixture of 8-chloro-2-(2,6-difluorophenylmethyl)-2,3-dihydro-3-methyl1,2,5-benzothiadiazepin-4(5h)-one 1,1-dioxide into a single enantiomer via a chromatographic resolution/racemization method. Chirality 15 (2003) 429-432.

29. R. Cirilli, R. Costi, R. Di Santo, M. Artico, A. Roux, B. Gallinella, L. Zanitti, F. La Torre. Enantioselective liquid chromatography of $\mathrm{C}_{3}$-chiral 2,3-dihydro-1,2,5benzothiadiazepin-4(5H)-one and thione 1,1-dioxides on polyacrylamide- and polysaccharide-based chiral stationary phases. Journal of Chromatography A 993 (2003) 17-28.

30. R. Kučera, M. Nobilis, L. Skalova, B. Szotakova, P. Cisai, T. Jira, J. Klimes, V. Wsol. Use of chiral liquid chromatography for the evaluation of stereospecificity in the carbonyl reduction of potential benzo[c]fluorene antineoplastics benfluron and dimefluron in various species. Journal of Pharmaceutical and Biomedical Analysis 37 (2005) 1049-1057.

31. I.A. Sayyed, V.V. Thakur, M.D. Nikalje, G.K. Dewkar, S.P. Kotkar, A. Sudalai. Asymmetric synthesis of aryloxypropanolamines via $\mathrm{OsO}_{4}$-catalyzed asymmetric dihydroxylation. Tetrahedron 61 (2005) 2831-2838.

32. A.S. Paraskar, A. Sudalai. Enantioselective synthesis of (-)-cytoxazone and (+)-epicytoxazone, novel cytokine modulators via Sharpless asymmetric epoxidation and L-proline catalyzed Mannich reaction. Tetrahedron 62 (2006) 5756-5762.

33. G. Cannazza, D. Braghiroli, P. Juliani, C. Parenti. Energy barrier determination of enantiomerization of chiral 3,4-dihydro-1,2,4-benzothiadiazine 1,1-dioxide type 
compounds by enantioselective stopped-flow HPLC. Tetrahedron: Asymmetry 17 (2006) 3158-3162.

34. G. Cannazza, M.M. Carrozzo, D. Braghiroli, C. Parenti. Enantiomerization of chiral 2,3,3a,4-tetrahydro-1 $H$-pyrrolo[2,1- $c][1,2,4]$ benzothiadiazine $\quad$ 5,5-dioxide $\quad$ by stopped-flow multidimensional HPLC. Journal of Chromatography B 875 (2008) 192-199.

35. G. Cannazza, M.M. Carrozzo, U. Battisti, D. Braghiroli, C. Parenti. On-line racemization by high-performance liquid chromatography. Journal of Chromatography A 1216 (2009) 5655-5659.

36. D.J. Cram, G.M. Lein. Host-guest complexation. 36. Spherand and lithium and sodium complexation rates equilibria. Journal of the American Chemical Society 107 (1985) 3657-3668.

37. S.G. Allenmark. Chromatographic enantioseparation: methods and applications, Ellis Horwood Limited, New York, 1988.

38. W. Saenger, J. Jacob, K. Gessler, T. Steiner, D. Hoffman, H. Sanbe, K. Koizumi, S.M. Smith, T. Takaha. Structure of the common cyclodextrins and their larger analogues - beyond the doughnut. Chemical Reviews 98 (1998) 1787-1802.

39. D.W. Armstrong, T.J. Ward, R.D. Armstrong, T.E. Beesley. Separation of drug stereoisomers by formation of b-cyclodextrin inclusion complexes. Science 232 (1986) 1132-1134.

40. S.M. Han, Y.I. Han, D.W. Armstrong. Structural factors affecting the chiral recognition and separation on ?-cyclodextrin bonded phase. Journal of Chromatography A 441 (1988) 376-381.

41. J.I. Seeman, H.V. Secor, D.W. Armstrong, K.D. Timmons, T.J. Ward. Enantiomeric resolution and chiral recognition of racemic nicotine and nicotine analogues by ?cyclodextrins complexatin. Structure-enantriomeric resolution relationship in host guest interaction. Analytical Chemistry 60 (1988) 2120-2127.

42. A. Berthod, L. Berthod, D.W. Armstrong. Selectivity of a native ?-cyclodextrin column in the separation of catechins. Journal of Liquid Chromatography \& Related Technologies 28 (2005) 1669-1678.

43. A.M. Stalcup, S.-C. Chang, D.W. Armstrong. Effect of the configuration of the substituents of derivatized b-cyclodextrin bonded phases on enantioselectivity in normal phase liquid chromatography. Journal of Chromatography A. 540 (1991) 113-128.

44. D.W. Armstrong, A.M. Stalcup, M.L. Hilton, J.D. Duncan, J. J. R. Faulkner, S.-C. Chang. Derivatized cyclodextrins for normal phase liquid chromatographic separation of enantiomers. Analytical Chemistry 62 (1990) 1610-1615.

45. D.J. Cram, J.M. Cram. Host-guest-chemistry. Science 183 (1974) 803-809.

46. D.S. Lingenfelter, R.G. Helgeson, D.J. Cram. Host-guest complexation. 23. High chiral recognitioni of amino acid and ester guests by hosts containing one chiral element. The Journal of Organic Chemistry 46 (1981) 393-406.

47. T. Shimbo, T. Yamaguchi, H. Yanagishita, D. Kitamoto, K. Sakaki, M. Sugiura. Improved crown ether-based stationary phase. Journal of Chromatography A 625 (1992) 101-108. 
48. T. Shimbo, T. Yamaguchi, K. Nishimura, M. Sugiura. Chromatographic separation of racemic amino acids by use of chiral crown ether-coated reversed-phase packings. Journal of Chromatography A 405 (1987) 145-153.

49. R.A. Thompson, Z. Gee, N. Grinberg, D. Ellison, P. Tway. Mechanistic aspects of the stereospecific interaction for aminoindanol with crown ether column. Analytical Chemistry 67 (1995) 1580-1587.

50. S. Chen, H. Yuan, N. Grinberg, A. Dovletoglou, G. Bicker. Enantiomeric separation of trans-2-aminocyclohexanol on a crown ether stationary phase using evaporative light scattering detection. Journal of Liquid Chromatography \& Related Technologies 26 (2003) 425-442.

51. M.H. Hyun, J.S. Jin, W. Lee. Liquid chromatographic resolution of racemic amino acids and their derivatives on a new chiral stationary phase based on crown ether. Journal of Chromatography A 822 (1998) 155-161.

52. H. J. Choi, M.H. Hyun. Liquid chromatographic chiral separation by Crown Etherbased chiral stationary phases. Journal of Liquid Chromatography \& Related Technologies 30 (2007) 853-875.

53. E. Bang, J.-W. Jung, W. Lee, D.W. Lee, W. Lee. Chiral recognition of (18-crown6)tetracarboxylic acid as a chiral selector determined by NMR spectroscopy. Journal of the Chemical Society, Perkin Transactions II (2001) 1685-1692.

54. S.C. Ng, L. Chen, L.F. Zhang, C.B. Ching. Facile preparative HPLC enantioseparation of racemic drugs using chiral stationary phases based on mono- $6^{\mathrm{A}}$-azido- $6^{\mathrm{A}}$-deoxyperphenylcarbamoylated $\beta$-cyclodextrin immobilized on silica gel. Tetrahedron Letters 43 (2002) 677-681.

55. O.A. Shpigun, E.N. Shapovalova, I.A. Ananieva, A.V. Pirogov. Separation and enantioseparation of derivatized amino acids and biogenic amines by highperformance liquid chromatography with reversed and chiral stationary phases. Journal of Chromatography A 979 (2002) 191-199.

56. S.C. Ng, T.T. Ong, P. Fu, C.B. Ching. Enantiomer separation of flavour and fragrance compounds by liquid chromatography using novel urea-covalent bonded methylated $\beta$-cyclodextrins on silica. Journal of Chromatography A 968 (2002) 3140.

57. M. Kaspereit, P. Jandera, M. Skavrada, A. Seidel-Morgenstern. Impact of adsorption isotherm parameters on the performance of enantioseparation using simulated moving bed chromatography. Journal of Chromatography A 944 (2002) 249-262.

58. D.W. Armstrong, Y.S. Liu, L.F. He, K.H. Ekborg-Ott, C.L. Barnes, C.F. Hammer. Potent enantioselective auxin: indole-3-succinic acid. Journal of Agricultural and Food Chemistry 50 (2002) 473-476.

59. C. Pham-Huy, G. Villain-Pautet, H. Hua, N. Chikhi-Chorfi, H. Galons, M. Thevenin, J.R. Claude, J.M. Warnet. Separation of oxazepam, lorazepam, and temazepam enantiomers by HPLC on a derivatized cyclodextrin-bonded phase: application to the determination of oxazepam in plasma. Journal of Biochemical and Biophysical Methods 54 (2002) 287-299.

60. L. Chen, L.F. Zhang, C.B. Ching, S.C. Ng. Synthesis and chromatographic properties of a novel chiral stationary phase derived from heptakis(6-azido-6-deoxy-2,3-di-Ophenylcarbamoylated)- $\beta$-cyclodextrin immobilized onto amino-functionalized silica gel via multiple urea linkages. Journal of Chromatography A 950 (2002) 6574. 
61. K. Hrobonova, J. Lehotay, J. Cizmarik, M. Rencova, D.W. Armstrong. Study of mechanism of enantioseparation. II. HPLC chiral analysis of alkoxysubstituted esters of phenycarbamic acid. Journal of Liquid Chromatography \& Related Technologies 25 (2002) 1711-1720.

62. Y. Makino, Y. Urano, T. Nagano. Impurity profiling of ephedrines in methamphetamine by high-performance liquid chromatography. Journal of Chromatography A 947 (2002) 151-154.

63. E. Lipka, M.P. Vaccher, E. Fourmaintraux, J.P. Bonte, C. Vaccher. Chiral Separation and Determination of the Enantiomeric Purity of Tetrahydronaphthalenic Derivatives, Melatoninergic Ligands, by HPLC using ß-Cyclodextrins. Chromatographia 58 (2003) 665-670.

64. F.C. Kugelberg, B. Carlsson, J. Ahlner, F. Bengtsson. Stereoselective single-dose kinetics of citalopram and its metabolites in rats. Chirality 15 (2003) 622-629.

65. H. Matsuzawa, K. Mikami. Efficient enantiomeric resolution via introduction of a fluorous tag as a resolving reagent with $\beta$-cyclodextrin columns model study on fluorinated $O$-acetylmandelate and ibuprofen amide. Tetrahedron Letters 44 (2003) 6227-6230.

66. Y.C. Tsai, T.-H. Liao, J.-A. Lee. Identification of L-3-hydroxybutyrate as an original ketone body in rat serum by column-switching high-performance liquid chromatography and fluorescence derivatization. Analytical Biochemistry $\mathbf{3 1 9}$ (2003) 34-41.

67. S. Chen. The HPLC Enantioresolution of Phenyl Isocyanated Amino Acids, Peptides and Amino Alcohols on Cyclodextrin Bonded Phases Using the Acetonitrile-Based Mobile phase. Chromatographia 59 (2004) 697-703.

68. S.C. Ng, C.B. Ching, L. Zhang, and L. Chen, US Patent, v. 6720285 (2004).

69. J.G. Gerber, R.J. Rhodes, J. Gal. Stereoselective metabolism of methadone Ndemethylation by cytochrome P4502B6 and 2C19. Chirality 16 (2004) 36-44.

70. S. Chen, T. Ward. Comparison of the chiral separation of amino-acid derivatives by a teicoplanin and $R \mathrm{~N}-\beta-\mathrm{CD}$ CSPs using waterless mobile phases: Factors that enhance resolution. Chirality 16 (2004) 318-330.

71. R. Goda, N. Murayama, Y. Fujimaki, K. Sudo. Simple and sensitive liquid chromatography-tandem mass spectrometry method for determination of the $S(+)$ - and $R(-)$-enantiomers of baclofen in human plasma and cerebrospinal fluid. Journal of Chromatography B $\mathbf{8 0 1}$ (2004) 257-264.

72. E. Lipka, V. Glaçon, G. Mackenzie, D. Ewing, C. Len, D. Postel, M.-P. Vaccher, J.-P. Bonte, C. Vaccher. HPLC Separation and Determination of Enantiomeric Purity of Novel Nucleoside Analogs, on Cyclodextrin Chiral Stationary Phases, Using Reversed and Polar Organic Modes. Analytical Letters 37 (2005) 385-398.

73. M.M. Warnke, C.R. Mitchell, R.V. Rozhkov, D.E. Emrich, R.C. Larock, D.W. Armstrong. Use of native and derivatized cyclodextrins based and macrocyclic glycopeptides based chiral stationary phases for the enantioseparation of pterocarpans by HPLC. Journal of Liquid Chromatography \& Related Technologies 28 (2005) 823-834.

74. X. Han, T. Yao, Y. Liu, R.C. Larock, D.W. Armstrong. Separation of chiral furan derivatives by liquid chromatography using cyclodextrin-based chiral stationary phases. Journal of Chromatography A 1063 (2005) 111-120. 
75. R.J. Soukup, R.V. Rozhkov, R.C. Larock, D.W. Armstrong. The Use of CyclodextrinBased LC Stationary Phases for the Separation of Chiral Dihydrobenzofuran Derivatives. Chromatographia 61 (2005) 219-224.

76. H. He, C. Sun, X.R. Wang, C. Pham-Huy, N. Chikhi-Chorfi, H. Galons, M. Thevenin, J.R. Claude, J.M. Warnet. Solid-phase extraction of methadone enantiomers and benzodiazepines in biological fluids by two polymeric cartridges for liquid chromatographic analysis. Journal of Chromatography B 814 (2005) 385-391.

77. X. Han, Q. Zhong, D. Yue, N. Della Ca, R.C. Larock, D.W. Armstrong. Separation of Enantiomers of Isochromene Derivatives by HPLC Using Cyclodextrin-Based Stationary Phases. Chromatographia 61 (2005) 205-211.

78. Z. Wimmer, D. Saman, M. Zarevucka, M. Wimmerova. Synthesis of the $(1 S, 2 S)$ - and $(1 R, 2 S)$-stereoisomers of the respective $E$ - and $Z$-isomers of ethyl 4-[(2hydroxycyclohexyl)methyl]phenoxy-3-methyl-2-butenoate using yeast whole cell bioreduction of the parent ketones. Tetrahedron: Asymmetry 16 (2005) 28102815.

79. Y.F. Poon, I.W. Muderawan, S.C. Ng. Synthesis and application of mono- $2^{A}$-azido- $2^{A_{-}}$ deoxyperphenylcarbamoylated $\quad \beta$-cyclodextrin and mono- $2^{A_{\text {-azido-}}} 2^{A_{-}}$ deoxyperacetylated $\beta$-cyclodextrin as chiral stationary phases for highperformance liquid chromatography. Journal of Chromatography A 1101 (2006) 185-197.

80. R. Bhushan, D. Gupta. HPLC resolution of thioridazine enantiomers from pharmaceutical dosage form using cyclodextrin-based chiral stationary phase. Journal of Chromatography B 837 (2006) 133-137.

81. K. Huang, Z.S. Breitbach, D.W. Armstrong. Synthesis of the $(1 S, 2 S)$ - and $(1 R, 2 S)-$ stereoisomers of the respective $E$ - and $Z$-isomers of ethyl 4-[(2hydroxycyclohexyl)methyl]phenoxy-3-methyl-2-butenoate using yeast whole cell bioreduction of the parent ketones. Tetrahedron Asymmetry 17 (2006) 2821-2832.

82. R. Koeppen, R. Becker, F. Emmerling, C. Jung, I. Nehls. Enantioselective preparative HPLC separation of the HBCD-Stereoisomers from the technical product and their absolute structure elucidation using X-ray crystallography. Chirality 19 (2007) 214-222.

83. V. Bavetsias, E.A. Henderson, E. McDonald. Cyclopenta[g]quinazolinone-based inhibitors of thymidylate synthase targeting $\alpha$-folate receptor overexpressing tumours: synthetic approaches to $4-\{N-[(6 R S)-2$-hydroxymethyl-4-oxo-3,4,7,8tetrahydro-6 $\mathrm{H}$-cyclopenta[g]quinazolin-6-yl]- $\mathrm{N}$-(prop-2-ynyl)amino\}benzoic acid. Tetrahedron 63 (2007) 1537-1543.

84. A.M. Palmer, V. Chiesa, H.C. Holst, J. Le Paih, A. Zanotti-Gerosa, U. Nettekoven. Synthesis of enantiopure 3,6,7,8-tetrahydrochromeno[7,8- $d$ ]imidazoles via asymmetric ketone hydrogenation in the presence of $\mathrm{RuCl}_{2}$ [Xyl-P-Phos][DAIPEN. Tetrahedron: Asymmetry 19 (2008) 2102-2110.

85. C. Ewert, S. Lutz-Wahl, L. Fischer. Enantioselective conversion of $\alpha$-arylnitirles by Klebsiella oxytoca. Tetrahedron: Asymmetry 19 (2008) 2573-2578.

86. W.M. Barker, K. Worm, R.E. Dolle. High-performance liquid chromatographic enantioseparation of methanobenzazocines. Journal of Chromatography A 1216 (2009) 7708-7714. 
87. J.-Y. Zheng, Z. Wang, Q. Zhu, Y.-J. Zhang, H.-D. Yan. Resolution of biotin intermediate lactone by enzyme catalyzed stereoselective lactonization in organic solvent. Journal of Molecular Catalysis B: Enzymatic. 56 (2009) 20-23.

88. R. Bhushan, R. Kumar. Comparative application of microwave, ultrasonication, ultracentrifugation and conventional heating for preparation of sample as dinitrophenyl derivative for direct enantioseparation of certain amino alcohols and 1-amino-2-propanol from vitamin $B_{12}$ hydrolysate on $\alpha_{1}$-acid glycoprotein and $\beta$ cyclodextrin columns. Journal of Chromatography A 1216 (2009) 7941-7945.

89. K. Nikolić, K. Ivković, Ž. Bešović, S. Marković, D. Agbaba. A validated enantiospecific method for determination and purity assay of clopridogel. Chirality 21 (2009) 878885.

90. M. Shishovska, V. Trajkovska. HPLC-method for determination of permethrin enantiomers using chiral $\beta$-cyclodextrin-based stationary phase. Chirality 22 (2010) 527-533.

91. M.I. Youshko, F. van Rantwijk, R.A. Sheldon. Enantioselective acylation of chiral amines catalysed by aminoacylase I. Tetrahedron: Asymmetry 12 (2001) 32673271.

92. P. Lopez-Serrano, M.A. Wegman, F. van Rantwijk, R.A. Sheldon. Enantioselective enzyme catalysed ammoniolysis of amino acid derivatives. Effect of temperature. Tetrahedron: Asymmetry 12 (2001) 235-240.

93. Peter, L. Lazar, F. Fulop, D.W. Armstrong. High-performance liquid chromatographic enantioseparation of $\beta$-amino acids. Journal of Chromatography $A$ 926 (2001) 229-238.

94. M.X. Wang, S.J. Lin. Practical and Convenient Enzymatic Synthesis of Enantiopure $\alpha$-Amino Acids and Amides. The Journal of Organic Chemistry 67 (2002) 6542 6545.

95. R. Watanabe, M. Kita, D. Uemura. A novel dipeptide, $N$ - $\gamma$-glutamyl boletine, and a cyclic iminium toxin from the mushroom Tylopilus sp. (Boletaceae). Tetrahedron Letters 43 (2002) 6501-6504.

96. T.N. Johansen, Y.L. Janin, B. Nielsen, K. Frydenvang, H. Bräuner-Osborne, T.B. Stenbol, S.B. Vogensen, U. Madsen, P. Krogsgaard-Larsen. 2-Amino-3-(3-hydroxy1,2,5-thiadiazol-4-yl)propionic acid: resolution, absolute stereochemistry and enantiopharmacology at glutamate receptors. Bioorganic and Medicinal Chemistry 10 (2002) 2259-2266.

97. S. Chen, H. Yuan, N. Grinberg, A. Dovletoglou, G. Bicker. Enantiomeric separation of trans-2-aminocyclohexanol on a crown ether stationary phase using evaporative light scattering detection. Journal of Liquid Chromatography \& Related Technologies 26 (2003) 425-442.

98. R. Nonokawa, E. Yashima. Detection and Amplification of a Small Enantiomeric Imbalance in $\alpha$-Amino Acids by a Helical Poly(phenylacetylene) with Crown Ether Pendants. Journal of the American Chemical Society 125 (2003) 1278-1283.

99. B.-F. Li, K. Yuan, M.-J. Zhang, H. Wu, L.-X. Dai, Q.R. Wang, X.-L. Hou. Highly Diastereoselective Strecker Reaction of Enolizable Aliphatic Sulfinimes. The Journal of Organic Chemistry 68 (2003) 6264-6267.

100. M.I. Youshko, L.M. van Langen, R.A. Sheldon, V.K. Svedas. Application of aminoacylase I to the enantioselective resolution of $\alpha$-amino acid esters and amides. Tetrahedron: Asymmetry 15 (2004) 1933-1936. 
101. T. Sonke, B. Kaptein, A.F.V. Wagner, P.J.L.M. Quaedflieg, S. Schultz, S. Ernste, A. Schepers, J.H.M. Mommers, Q.B. Broxterman. Peptide deforrmylase as biocatalysts for the synthesis of enantiomerically pure amino acid derivatives. Journal of Molecular Catalysis B: Enzymatic. 29 (2004) 265-277.

102. Nishiyama, A., N. Kishimoto, and N. Nagashima, US Patent Application; Patent Version Number 20050277791 (2005).

103. Hom, R., J. Tucker, V. John, and N. Shah, US Patent Application, v. 20050267199 (2005).

104. Y. Asano, S. Yamaguchi. Dynamic Kinetic Resolution of Amino Acid Amide Catalyzed by D-Aminopeptidase and $\alpha$-Amino- $\varepsilon$-caprolactam Racemase. Journal of the American Chemical Society 127 (2005) 7696-7697.

105. U. Müller, F. van Assema, M. Gunsio, S. Orf, S. Kremer, D. Schipper, A. Wagemans, C.A. Townsend, T. Sonke, R. Bovenberg, M. Wubbolts. Metabolic engineering of the E. coliL-phenylalanine pathway for the production of D-phenylglycine (D-Phg). Metabolic Engineering 8 (2006) 196-208.

106. V. Zimmermann, M. Beller, U. Kragl. Modelling the reaction course of a dynamic kinetic resolution of amino acid derivatives: identifying and overcoming bottlenecks. Organic Process Research and Development 10 (2006) 622-627.

107. C. Carboni, H.G.T. Kierkels, L. Gardossi, K. Tamiola, D.B. Janssen, P.J.L.M. Quaedflieg. Preparation of D-amino acids by enzymatic kinetic resolution using a mutant of penicillin-G acylase from E. coli. Tetrahedron: Asymmetry 17 (2006) 245-251.

108. Pannuri, S., S. Kamat, and A.R. Martin-Garcia, US Patent Application, v. 20070134772, (2007).

109. A. Yoshida, S. Hikichi, N. Mizuno. Acid-base catalyses by dimeric disilicoicosatungstates and divacant $\gamma$-Keggin-type silicodecatungstate parent: Reactivity of the polyoxometalate compounds controlled by step-by-step protonation of lacunary $\mathrm{W}=0$ sites. Journal of Organometallic Chemistry 692 (2007) 455-459.

110. Y. Hattori, T. Asano, M. Kirihata, Y. Yamaguchi, T. Wakamiya. Development of the first and practical method for enantioselective synthesis of ${ }^{10} \mathrm{~B}$-enriched $p$-boronoL-phenylalanine. Tetrahedron Letters 49 (2008) 4977-4980.

111. R.P. Clausen, C. Christensen, K.B. Hansen, J.R. Greenwood, L. Jørgensen, N. Micale, J.C. Madsen, B. Nielsen, J. Egebjerg, H. Bräuner-Osborne, S.F. Traynelis, J.L. Kristensen. $N$-Hydroxypyrazolyl Glycine Derivatives as Selective $N$-Methyl-Daspartic Acid Receptor Ligands. Journal of Medicinal Chemistry 51 (2008) 41794187.

112. J. Zheng, H. Zhu, K. Hong, Y. Wang, P. Liu, X. Wang, X. Peng, W. Zhu. Novel Cyclic Hexapeptides from Marine-Derived Fungus, Aspergillus sclerotiorum PT06-1. Organic Letters 11 (2009) 5262-5265.

113. C. Fernandes, E. Pereira, S. Faure, D.J. Aitken. Expedient preparation of all isomers of 2-aminocyclobutanecarboxylic acid in enantiomerically pure form. The Journal of Organic Chemistry 74 (2009) 3217-3220.

114. T. Nuijens, C. Cusan, J.A.W. Kruijtzer, D.T.S. Rijkers, R.M.J. Liskamp, P.J.L.M. Quaedflieg. Enzymatic Synthesis of $C$-Terminal Arylamides of Amino Acids and Peptides. The Journal of Organic Chemistry 74 (2009) 5145-5150. 
115. C. Selvam, N. Oueslati, I.A. Lemasson, I. Brabet, D. Rigault, T. Courtiol, S. Cesarini, N. Triballeau, H.-O. Bertrand, C. Goudet, J.-P. Pin, F.C. Acher. A virtual screening hit reveals new possibilities for developing group III metabotropic glutamate receptor agonists. Journal of Medicinal Chemistry 53 (2010) 2797-2813.

116. H. Yilmaz, G. Topal, R. Cakmak, H. Hosgoren. Resolution of ( \pm )- $\beta$ methylphenylethylamine by a novel chiral stationary phase for Pirkle-type column chromatography. Chirality 22 (2010) 252-257.

117. C.J. Bender. Theoretical models of chrage-transfer complexes. Chemical Society Reviews 15 (1986) 475-502.

118. F. Gutmann, C. Johnson, H. Keyzer, J. Molnar. Charge Transfer Complexes in Biological Systems, Marcel Dekker, Inc., New York, 1997.

119. M.L. Waters. Aromatic interactions in model systems. Current Opinion in Chemical Biology 6 (2002) 736-741.

120. W.B. Jennings, F.M. Farrell, J.F. Malone. Attractive intermolecular edge-to-face aromatic interactions in flexible organic molecules. Accounts of Chemical Research 34 (2001) 885-894.

121. W.H. Pirkle. The nonequivalence of physical properties of enantiomers in Optically active solvents. Differences in nuclear magnetic resonance spectra. I. Journal of the American Chemical Society 88 (1966) 1837-1837.

122. W.H. Pirkle, D.L. Sikkenga. Resolution of optical isomers by liquid chromoatography. Journal of Chromatography A 123 (1976) 400-404.

123. W.H. Pirkle, D.W. House, J.M. Finn. Broad spectrum resolution of optical isomers using chiral high-performance liquid chromatographic bonded phases. Journal of Chromatography A 192 (1980) 143-158.

124. W.H. Pirkle, J. Finn. Separation of enantiomers by liquid chromatographic methods. In Asymmetric synthesis. Analytical methods. (Eds. J.D. Morrison, J.W: Scott) Academic Press, New York, 1983, p. 87.

125. R. Thompson. A Practical guide to HPLC enantioseparations for pharmaceutical compounds. Journal of Liquid Chromatography \& Related Technologies 28 (2005) 1215-1231.

126. W.H. Pirkle, C.J. Welch, B. Lamm. Design, synthesis and evaluation of an improved enantioselective naproxen selector. The Journal of Organic Chemistry 57 (1992) 3854-3860.

127. M. Lammerhofer, W. Lindner. Quinine and quinidine derivatives as chiral selectors. Brush type chiral stationary phases for high performance liquid chromatography based on chincona carbamates and their applications as chiral anion exchanger. Journal of Chromatography A 741 (1966) 33-48.

128. M. Lammerhofer, W. Lindner. Liquid chromatographic enantiomer separation and chiral recognition by Cinchona Alcaloid-Derived Enantioselective Separation Materials. In Adavances in Chromatography (Eds. E. Grushka, N. Grinberg) CRC Press, Boca Raton, 2008, pp. 1-109.

129. S. Schefzig, W. Lindner, K.B. Lipkowitz, M. Jalaie. Enantiomeric discrimination by a quinine-based chiral stationary phase. A computational study. Chirality 12 (2000) 7-15. 
130. J. Clayden, D. Mitjans, L.H. Youssef. Lithium-Sulfoxide-Lithium Exchange for the Asymmetric Synthesis of Atropisomers under Thermodynamic Control. Journal of the American Chemical Society 124 (2002) 5266-5267.

131. W.F. Bailey, P. Beak, S.T. Kerrick, S. Ma, K.B. Wiberg. An Experimental and Computational Investigation of the Enantioselective Deprotonation of Bocpiperidine. Journal of the American Chemical Society 124 (2002) 1889-1896.

132. N.T. McDougal, S.E. Schaus. Asymmetric Morita-Baylis-Hillman Reactions Catalyzed by Chiral Brønsted Acids. Journal of the American Chemical Society 125 (2003) 12094-12095.

133. M.S. Taylor, E.N. Jacobsen. Enantioselective Michael Additions to $\alpha, \beta$-Unsaturated Imides Catalyzed by a Salen-Al Complex. Journal of the American Chemical Society 125 (2003) 11204-11205.

134. M.-J. Kim, Y.I. Chung, Y.K. Choi, H.K. Lee, D. Kim, J. Park. (S)-Selective Dynamic Kinetic Resolution of Secondary Alcohols by the Combination of Subtilisin and an Aminocyclopentadienylruthenium Complex as the Catalysts. Journal of the American Chemical Society 125 (2003) 11494-11495.

135. A. He, B. Yan, A. Thanavaro, C.D. Spilling, N.P. Rath. Synthesis of Nonracemic Allylic Hydroxy Phosphonates via Alkene Cross Metathesis. The Journal of Organic Chemistry 69 (2004) 8643-8651.

136. J.J. Ryoo, K.S. Heo, E.S. Choi, J.H. Park, W. Lee. Enantioseparation of tiropramide by HPLC. Chirality 16 (2004) S51-S54.

137. J.C.D. Le, B.L. Pagenkopf. Asymmetric Hydrogenation of o-Alkoxy-Substituted Arylenamides. The Journal of Organic Chemistry 69 (2004) 4177-4180.

138. P.V. Ramachandran, S. Madhi, L. Bland-Berry, M.V.R. Reddy, M.J. O'Donnell. Catalytic Enantioselective Synthesis of Glutamic Acid Derivatives via Tandem Conjugate Addition-Elimination of Activated Allylic Acetates under Chiral PTC Conditions. Journal of the American Chemical Society 127 (2005) 13450-13451.

139. M.P. Doyle, J.P. Morgan, J.C. Fettinger, P.Y. Zavalij, J.T. Colyer, D.J. Timmons, M.D. Carducci. "Matched/Mismatched" Diastereomeric Dirhodium(II) Carboxamidate Catalyst Pairs. Structure-Selectivity Correlations in Diazo Decomposition and Hetero-Diels-Alder Reactions. The Journal of Organic Chemistry 70 (2005) 52915301.

140. J. Huang, P. Zhang, H. Chen, T. Li. Preparation and Evaluation of Proline-Based Chrial Columns. Analytical Chemistry 77 (2005) 3301-3308.

141. A. Ting, S. Lou, S.E. Schaus. Highly diastereoselective asymmetric Mannich reactions of 1,3-dicarbonyls with acyl imines. Organic Letters 8 (2006) 2003-2006.

142. A.L. Simplicio, P. Matias, J.F. Gilmer, J.M. Clancy. Chiral separation and identification of $\beta$-aminoketones of pharmacological interest by high performance liquid chromatography and capillary electrophoresis. Journal of Chromatography A 1120 (2006) 89-93.

143. C.J. Welch, M. Biba, P. Sajonz. Fast methods of enantiopurity determination for the Soai reaction: Towards a general enantioenrichment detector?. Chirality 19 (2007) 34-43.

144. D. Liu, E. Canales, E.J. Corey. Chiral Oxazaborolidine-Aluminum Bromide Complexes Are Unusually Powerful and Effective Catalysts for Enantioselective 
Diels-Alder Reactions. Journal of the American Chemical Society 129 (2007) 14981499.

145. A.V. Malkov, S. Stoncius, K. Vrankova, M. Arndt, P. Kocovsky. Dynamic Kinetic Resolution in the Asymmetric Synthesis of $\beta$-Amino Acids by Organocatalytic Reduction of Enamines with Trichlorosilane. Chemistry - A European Journal 14 (2008) 8082-8085.

146. X. Lu, L. Deng. Asymmetric Aza-Michael Reactions of $\alpha, \beta$-Unsaturated Ketones with Bifunctional Organic Catalysts. Angewandte Chemie International Edition (English) 47 (2008) 7710-7713.

147. P.H. Fuller, J-W. Kim, S.R. Chemler. Copper Catalyzed Enantioselective Intramolecular Aminooxygenation of Alkenes. Journal of the American Chemical Society 130 (2008) 17638-17639.

148. C. Curti, A. Sartori, L. Battistini, G. Rassu, F. Zanardi, G. Casiraghi. Asymmetric, catalytic, vinylogous aldol reactions using pyrrole-based dienoxy silanes. Enantioselective synthesis of $\alpha, \beta$-unsaturated $\gamma$-butyrolactam synthons. Tetrahedron Letters 50 (2009) 3428-3431.

149. A.E. Nibbs, A.-L. Baize, R.M. Herter, K.A. Scheidt. Catalytic asymmetric alkylation of substituted isoflavanones. Organic Letters 11 (2009) 4010-4013.

150. R. Aneja, P. Luthra, S. Ahuja. High-performance liquid chromatography separation of enantiomers of mandelic acid and its analogs on a chiral stationary phase. Chirality 22 (2010) 479-485.

151. Z. Li, H.M.L. Davies. Enantioselective C-C Bond Formation by Rhodium-Catalyzed Tandem Ylide Formation/[2,3]-Sigmatropic Rearrangement between Donor/Acceptor Carbenoids and Allylic Alcohols. Journal of the American Chemical Society 132 (2010) 396-401.

152. A. Peter, E. Vekes, A. Arki, D. Tourwe, W. Lindner. Direct high-performance liquid chromatographic enantioseparation of $\alpha$-substituted proline analogues on a quinine-derived chiral anion-exchanger stationary phase. Journal of Separation Science 26 (2003) 1125-1132.

153. M. Lammerhofer, D. Hebenstreit, E. Gavioli, W. Lindner, A. Mucha, P. Kafarski, P. Wieczorek. High-performance liquid chromatographic enantiomer separation and determination of absolute configurations of phosphinic acid analogues of dipeptides and their $\alpha$-aminophosphinic acid precursors. Tetrahedron: Asymmetry 14 (2003) 2557-2565.

154. W. Bicker, M. Lammerhofer, W. Lindner. Direct high-performance liquid chromatographic method for enantioselective and diastereoselective determination of selected pyrethroic acids. Journal of Chromatography A $\mathbf{1 0 3 5}$ (2004) 37-46.

155. K. Gyimesi-Forras, J. Kokosi, G. Szasz, A. Gergely, W. Lindner. Liquid chromatographic enantiomer separations of novel quinazolone derivatives on quinine carbamate based chiral stationary phases using hydro-organic mobile phases. Journal of Chromatography A 1047 (2004) 59-67.

156. K. Gyimesi-Forras, A. Leitner, A. Akasaka, W. Lindner. Comparative study on the use of ortho-phthalaldehyde, naphthalene-2,3-dicarboxaldehyde and anthracene2,3-dicarboxaldehyde reagents for $\alpha$-amino acids followed by the enantiomer separation of the formed isoindolin-1-one derivatives using quinine-type chiral stationary phases. Journal of Chromatography A 1083 (2005) 80-88. 
157. K. Gyimesi-Forras, K. Akasaka, M. Lammerhofer, N.M. Maier, T. Fujita, M. Watanabe, N. Harada, W. Lindner. Enantiomer separation of a powerful chiral auxiliary, 2methoxy-2-(1-naphthyl)propionic acid by liquid chromatography using chiral anion exchanger-type stationary phases in polar-organic mode; investigation of molecular recognition aspects. Chirality 17 (2005) S134-S142.

158. X. Xiong, W.R.G. Baeyens, H.Y. Aboul-Enein, J.R. Delanghe, T. Tu, J. Ouyang. cComparison of performance of Chirobiotic T, T2 and TAG columns in the separation of $\beta^{2}$ - and $\beta^{3}$-homoamino acids. Talanta 71 (2007) 573-581.

159. Y. Tojo, K. Hamase, M. Nakata, A. Morikawa, M. Mita, Y. Ashida, W. Lindner, K. Zaitsu. Automated and simultaneous two-dimensional micro-high-performance liquid chromatographic determination of proline and hydroxyproline enantiomers in mammals. Journal of Chromatography B 875 (2008) 174-179.

160. V.A. Davankov. Ligand exchange chromatography of chiral compounds. In: Complexation chromatography (Ed. D. Cagniant) Marcel Dekker, New York, 1992, p. 197.

161. F. Helfferich. Ligand exchange: a novel separation technique. Nature 189 (1961) 1001-1002.

162. S.V. Rogozhin, V.A. Davankov. Ligand chromatography on asymmetric complexforming sorbent as a new method for resolution of racemates. Journal of the Chemical Society D: Chemical Communications (1971) 490.

163. A.M. Rizzi. Efficiency in chiral high performance ligand exchange chromatography. Influence of complexation process, flow rate and capacity factor. Journal of Chromatography A 542 (1991) 221-237.

164. M.H. Hyun, S.C. Han, C.W. Lee, Y.K. Lee. Preparation and application of a new ligand exchange chiral stationary phase for the liquid chromatographic resolution of $\alpha$ amino acid enantiomers. Journal of Chromatography A 950 (2002) 55-63.

165. H. Luesch, P.G. Williams, W.Y. Yoshida, R.E. Moore, V.J. Paul. Ulongamides A-F, New $\beta$-Amino Acid-Containing Cyclodepsipeptides from Palauan Collections of the Marine Cyanobacterium Lyngbya sp. Journal of Natural Products 65 (2002) 9961000.

166. P.G. Williams, W.Y. Yoshida, R.E. Moore, V.J. Paul. Tasiamide, a Cytotoxic Peptide from the Marine Cyanobacterium Symploca sp. Journal of Natural Products 65 (2002) 1336-1339.

167. H. Luesch, D. Hoffmann, J.M. Hevel, J.E. Becker, T. Golakoti, R.E. Moore. Biosynthesis of 4-Methylproline in Cyanobacteria: Cloning of nosE and nosF Genes and Biochemical Characterization of the Encoded Dehydrogenase and Reductase Activities. The Journal of Organic Chemistry 68 (2003) 83-91.

168. H. Pajouhesh, K. Curry, H. Palouhesh, M.H. Maresht, B. Patrick. Stereospecific synthesis and absolute configuration of the $(2 S, 3 S, 4 S)$-isomer of 2-methyl-2(carboxycyclopropyl)glycine (MCCG). Tetrahedron: Asymmetry 14 (2003) 593-596.

169. X. Huang, J. Wang, Q. Wang, B. Huang. Chiral Speciation and Determination of DLSelenomethionine Enantiomers on a Novel Chiral Ligand-Exchange Stationary Phase. Analytical Sciences 21 (2005) 253-257.

170. Y. Liu, H. Zou, J. Haginaka. Preparation and evaluation of a novel chiral stationary phase based on covalently bonded chitosan for ligand-exchange chromatography. Journal of Separation Science 29 (2006) 1440-1446. 
171. B. Natalini, R. Sardella, A. Macchiarulo, R. Pellicciari. $S$-Trityl- $(R)$-cysteine, a powerful chiral selector for the analytical and preparative ligand-exchange chromatography of amino acids. Journal of Separation Science 31 (2008) 696-704.

172. Vu, T.C., D.B. Brzozowski, R. Fox, J.D. Godfrey JR., R.L. Hanson, S.V. Kolotuchin, J.A. Mazzullo, R.N. Patel, J. Wang, K. Wong, J. Yu, J.J. Zhu, D.R. Magnin, D.J. Augeri, and L.G. Hamann, US Patent Application, v. 20090018311 (2009).

173. F.A. Carey. Organic Chemistry. The McGraw-Hill Companies Inc, New York, 1996.

174. A.L. Lehninger. Principles of biochemistry. Worth Publisher, Inc, New York, 1982.

175. M. Lederer. Adsorption chromatography. VI. Further studies on the separation of D-and L-tryprophan on cellulose with aqueous solvents. Journal of Chromatography A $\mathbf{5 1 0}$ (1990) 367-371.

176. M. Lederer. Adsorption chromatography. VII. Chiral separation on cellulose with aqueous solvents. Journal of Chromatography A 604 (1992) 55-62.

177. H.T.K. Xuan, M. Lederer, Adsorption chromatography. IX. Chiral separation with aqueous solvents and liquid-liquid systems. Journal of Chromatography A 635 (1993) 346-348.

178. T. Shibata, K. Mori, Y. Okamoto, Polysaccharide phases, in Chiral separation by HPLC. Appications to pharmaceutical compounds. (Ed. A.M. Krstulovic) Ellis Horwood, New York, 1989, p. 336.

179. Y. Okamoto, R. Aburatini, K. Hatada, Chromatographic chiral resolution. XIV. Cellulose tribenzoate derivatives as chiral stationary phases for high performance liquid chromatography. Journal of Chromatography A 389 (1987) 95-102.

180. E. Yashima, C. Yamamoto, Y. Okamoto. NMR studies of chiral discrimination relevant to liquid chromatographic enantioseparation by a cellulose phenyl carbamate derivative. Journal of the American Chemical Society 118 (1996) 40364048.

181. C.W. Amoss, N.M. Mayer, Separation of chiral compounds on Polysaccharide columns. In: Chiral separation methods for pharmaceutical and biotechnological products (Ed. S. Ahuja), John Wiley \& Sons, Inc., Hoboken, New Jersey, 2011, p. 57.

182. H. Ding, N. Grinberg, R. Thompson, D. Ellison. Enantiorecognition mechanism for derivatized cellulose under reversed phase conditions. Journal of Liquid Chromatography \& Related Technologies 23 (2000) 2641-2651.

183. R. Cirilli, R. Costi, R. Di Santo, R. Ferretti, F. La Torre, L. Angiolella, M. Micocci. Analytical and semipreparative enantiomeric separation of azole antifungal agents by high-performance liquid chromatography on polysaccharide-based chiral stationary phases: Application to in vitro biological studies. Journal of Chromatography A 942 (2002) 107-114.

184. K.W. Phinney, L.C. Sander. Preliminary evaluation of a standard reference material for chiral stationary phases used in liquid and supercritical fluid chromatography. Analytical and Bioanalytical Chemistry 372 (2002) 101-108.

185. E. Lipka-Belloli, C. Len, G. Mackenzie, G. Ronco, J.P. Bonte, C. Vaccher. Diastereomeric resolution of nucleoside analogues, new potential antiviral agents, using high-performance liquid chromatography on polysaccharide-type chiral stationary phases. Journal of Chromatography A 943 (2002) 91-100.

186. D.A. Evans, J. Wu. Enantioselective Rare-Earth Catalyzed Quinone Diels-Alder Reactions. Journal of the American Chemical Society 125 (2003) 10162-10163. 
187. N.S. Chowdari, D.B. Ramachary, C.F. Barbas. Organocatalytic Asymmetric Assembly Reactions: One-Pot Synthesis of Functionalized $\beta$-Amino Alcohols from Aldehydes, Ketones, and Azodicarboxylates. Organic Letters 5 (2003) 1685-1688.

188. S. Matsumura, Y. Maeda, T. Nishimura, S. Uemura. Palladium-Catalyzed Asymmetric Arylation, Vinylation, and Allenylation of tert-Cyclobutanols via Enantioselective C-C Bond Cleavage. Journal of the American Chemical Society 125 (2003) 88628869.

189. D.M. Hodgson, C.R. Maxwell, T.J. Miles, E. Paruch, I.R. Matthews, J. Witherington. Organolithium-induced enantioselective alkylative double ring-opening of epoxides: synthesis of enantioenriched unsaturated amino alcohols. Tetrahedron 60 (2004) 3611-3624.

190. E.N. Shapovalova, O.A. Shpigun, L.M. Nesterova, M.Y. Belov. Determination of the Optical Purity of Fungicides of the Triazole Series. Journal of Analytical Chemistry 59 (2004) 255-259.

191. B.H. Lipshutz, H. Shimizu. Copper(I)-Catalyzed Asymmetric Hydrosilylations of Imines at Ambient Temperatures. Angewandte Chemie International Edition (English) 43 (2004) 2228-2230.

192. Y. Yamashita, S. Kobayashi. Zirconium-Catalyzed Enantioselective [3+2] Cycloaddition of Hydrazones to Olefins Leading to Optically Active Pyrazolidine, Pyrazoline, and 1,3-Diamine Derivatives. Journal of the American Chemical Society 126 (2004) 11279-11282.

193. A. Hu, W. Lin. Ru-Catalyzed Asymmetric Hydrogenation of $\alpha$-Phthalimide Ketones and 1,3-Diaryl Diketones Using 4,4'-Substituted BINAPs. Organic Letters 7 (2005) 455-458.

194. P.C. B. Page, B.R. Buckley, H. Heany, A.J. Blacker. Asymmetric Epoxidation of cisAlkenes Mediated by Iminium Salts: Highly Enantioselective Synthesis of Levcromakalim. Organic Letters 7 (2005) 375-377.

195. D.A. Evans, K.R. Fandrick, H.J. Song. Enantioselective Friedel-Crafts Alkylations of $\alpha, \beta$-Unsaturated 2-Acyl Imidazoles batalyzed Bis(oxazolinyl)pyridine-Scandium(III) Triflate Complexes. Journal of the American Chemical Society 127 (2005) 8942-8943.

196. N. Matthijs, M. Maftouh, Y. Vander Heyden. Screening approach for chiral separation of pharmaceuticals: IV. Polar organic solvent chromatography. Journal of Chromatography A 1111 (2006) 48-61.

197. I. Coldham, S. Dufour, T.F.N. Haxell, J.J. Patel, G. Sanchez-Jimenez. Dynamic Thermodynamic and Dynamic Kinetic Resolution of 2-Lithiopyrrolidones. Journal of the American Chemical Society 128 (2006) 10943-10951.

198. D. Wiktelius, E.K. Larsson, K. Luthman. Chemoenzymatic synthesis of enantiomerically enriched $\alpha$-chiral 3-oxy-propionaldehydes by lipase-catalyzed kinetic resolution and desymmetrization. Tetrahedron: Asymmetry 17 (2006) 2088-2100.

199. G. Liu, X. Lu. Cationic Palladium Complex Catalyzed Highly Enantioselective Intramolecular Addition of Arylboronic Acids to Ketones. A Convenient Synthesis of Optically Active Cycloalkanols. Journal of the American Chemical Society 128 (2006) 16504-16505. 
200. Y. Jin, X.Y. Liu, L.L. Jing, W. He, X.L. Sun, S.Y. Zhang. Investigation on 1,4dichlorophthalazine-derivatized cinchona alkaloids-catalyzed asymmetric "interrupted" Feist-Bénary reaction. Chirality 19 ( 2007) 386-390.

201. H. Lebel, K. Huard. De Novo Synthesis of Troc-Protected Amines: Intermolecular Rhodium-Catalyzed $\mathrm{C}-\mathrm{H}$ Amination with $\mathrm{N}$-Tosyloxycarbamates. Organic Letters 9 (2007) 639-642.

202. S.Y. Wang, S.J. Ji, T.P. Loh. Cu(I) Tol-BINAP-Catalyzed Enantioselective Michael Reactions of Grignard Reagents and Unsaturated Esters. Journal of the American Chemical Society 129 (2007) 276-277.

203. A.V. Malkov, M. Figlus, S. Stoncius, P. Kocovsky. Organocatalysis with a Fluorous Tag: Asymmetric Reduction of Imines with Trichlorosilane Catalyzed by Amino Acid-Derived Formamides. The Journal of Organic Chemistry 72 (2007) 1315-1325.

204. J.-K. Jiang, K. Ghoreschi, F. Deflorian, Z. Chen, M. Perreira, M. Pesu, J. Smith, D.-T. Nguyen, E.H. Liu, W. Leister, S. Costanzi, J.J. O'Shea, C.J. Thomas. Examining the Chirality, Conformation and Selective Kinase Inhibition of 3-((3R,4R)-4-methyl-3(methyl(7H-pyrrolo[2,3- $d$ ]pyrimidin-4-yl)amino)piperidin-1-yl)-3-

oxopropanenitrile (CP-690,550). Journal of Medicinal Chemistry 51 (2008) 80128018.

205. M. Seto, J.L. Roizen, B.M. Stoltz. Catalytic Enantioselective Alkylation of Substituted Dioxanone Enol Ethers: Ready Access to C $(\alpha)$-Tetrasubstituted Hydroxyketones, Acids, and Esters. Angewandte Chemie International Edition (English) 47 (2008) 6873-6876.

206. D. Minato, Y. Nagasue, Y. Demizu, O. Onomura. Effecient Kinetic Resolution of Racemic Amino Aldehydes by Oxidation with $N$-Iodosuccinimide. Angewandte Chemie International Edition (English) 47 (2008) 9458-9461.

207. X.-L. Huang, X.-Y. Chen, S. Ye. Enantioselective Synthesis of Aza- $\beta$-lactams via NHCCatalyzed [2 + 2] Cycloaddition of Ketenes with Diazenediacarboxylates. The Journal of Organic Chemistry 74 (2009) 7585-7587.

208. M.K. Ghorai, D. Shukla, K. Das. Enantioselective Syntheses of Morpholines and Their Homologues via $\mathrm{S}_{\mathrm{N}} 2$-Type Ring Opening of Aziridines and Azetidines with Haloalcohols. The Journal of Organic Chemistry 74 (2009) 7013-7022.

209. X.-Y. Liu, C.-M. Che. Highly Enantioselective Synthesis of Chiral Secondary Amines by Gold(I)/Chiral Brønsted Acid Catalyzed Tandem Intermolecular Hydroamination and Transfer Hydrogenation Reactions. Organic Letters 11 (2009) 4204-4207.

210. S. Ma, S. Shen, H. Lee, M. Eriksson, X. Zeng, J. Xu, K. Fandrick, N. Yee, C. Senanayake, N. Grinberg. Mechanistic studies on the chiral recognition of polysaccharide-based chiral stationary phases using liquid chromatography and vibrational circular dichroism: Reversal of elution order of N-substituted alpha-methyl phenylalanine esters. Journal of Chromatography A 1216 (2009) 3784-3793.

211. D. Ding, C.-G. Zhao. Organocatalyzed synthesis of 2-amino-8-oxo-5,6,7,8tetrahydro-4H-chromene-3-carbonitriles. Tetrahedron Letters 51 (2010) 13221325.

212. B. Yang, M.J. Miller. Iminonitroso ene reactions: experimental studies on reactivity, regioselectivity and enantioselectivity. Tetrahedron Letters 51 (2010) 328-331.

213. N. Kanbayashi, K. Onitsuka. Enantioselective Synthesis of Allylic Esters via Asymmetric Allylic Substitution with Metal Carboxylates Using Planar-Chiral 
Cyclopentadienyl Ruthenium Catalysts. Journal of the American Chemical Society 132 (2010) 1206-1207.

214. Y. Bereznitski, R. Lobrutto, N. Variankaval, R. Thompson, K. Thopmpson, P. Sajonz, L.S. Crocker, J. Kowal, D. Cai, M. Journet, T. Wang, J. Wyvratt, N. Grinberg. Mechanistic aspects of chiral discriminatino on an Amylose tris(3,5dimethylphenyl)carbamate. Enantiomer 7 (2002) 305-315.

215. M. Matsushita, K. Yoshida, N. Yamamoto, P. Wirsching, R.A. Lerner, K.D. Janda. High-Throughput Screening by Using a Blue-Fluorescent Antibody Sensor. Angewandte Chemie International Edition (English) 42 (2003) 5984-5987.

216. H. Kanazawa, A. Okada, M. Higaki, H. Yokota, F. Mashige, K. Nakahara. Stereospecific analysis of omeprazole in human plasma as a probe for CYP2C19 phenotype. Journal of Pharmaceutical and Biomedical Analysis 30 (2003) 18171824.

217. S.P. Brown, M.P. Brochu, C.J. Sinz, D.W.C. MacMillan. The Direct and Enantioselective Organocatalytic $\alpha$-Oxidation of Aldehydes. Journal of the American Chemical Society 125 (2003) 10808-10809.

218. T. Ooi, M. Kameda, M. Taniguchi, K. Maruoka. Development of Highly Diastereoand Enantioselective Direct Asymmetric Aldol Reaction of a Glycinate Schiff Base with Aldehydes Catalyzed by Chiral Quaternary Ammonium Salts. Journal of the American Chemical Society 126 (2004) 9685-9694.

219. A. Cordova, H. Sunden, M. Engqvist, I. Ibrahem, J. Casas. The Direct Amino AcidCatalyzed Asymmetric Incorporation of Molecular Oxygen to Organic Compounds. Journal of the American Chemical Society 126 (2004) 8914-8915.

220. A.S. Demir, P. Ayhan, A.A. Igdir, A.N. Duygu. Enzyme catalyzed hydroxymethylation of aromatic aldehydes with formaldehyde. Synthesis of hydroxyacetophenones and (S)-benzoins. Tetrahedron 60 (2004) 6509-6512.

221. Q. Fan, L. Lin, J. Liu, Y. Huang, X. Feng, G. Zhang. Highly Enantioselective HeteroDiels-Alder Reaction of Brassard Diene with Aromatic Aldehydes. Organic Letters 6 (2004) 2185-2188.

222. T. Soeta, M. Kuriyama, K. Tomioka. Catalytic Asymmetric Conjugate Addition of Dialkylzinc Reagents to $\quad \beta$-Aryl- $\alpha, \beta$-unsaturated $\quad N$-2,4,6Triisopropylphenylsulfonylaldimines with Use of $N$-Boc-L-Val-Connected Amidophosphane-Copper(I) Catalyst. The Journal of Organic Chemistry 70 (2005) 297-300.

223. Y. Liu, K. Ding. Modular Monodentate Phosphoramidite Ligands for RhodiumCatalyzed Enantioselective Hydrogenation. Journal of the American Chemical Society 127 (2005) 10488-10489.

224. S. Lou, P.N. Moquist, S.E. Schaus. Asymmetric Allylboration of Ketones Catalyzed by Chiral Diols. Journal of the American Chemical Society 128 (2006) 12660-12661.

225. X.M. Deng, P. Cai, S. Ye, X.L. Sun, W.W. Liao, K. Li, Y. Tang, Y.D. Wu, L.X. Dai. Enantioselective Synthesis of Vinylcyclopropanes and Vinylepoxides Mediated by Camphor-Derived Sulfur Ylides: Rationale of Enantioselectivity, Scope, and Limitation. Journal of the American Chemical Society 128 (2006) 9730-9740.

226. Y. Fukuta, T. Mita, N. Fukuda, M. Kanai, M. Shibasaki. De Novo Synthesis of Tamiflu via a Catalytic Asymmetric Ring-Opening of meso-Aziridines with TMSN $\mathrm{T}_{3}$. Journal of the American Chemical Society 128 (2006) 6312-6313. 
227. Y. Wu, Y. Zhang, M. Yu, G. Zhao, S. Wang. Highly Efficient and Reusable Dendritic Catalysts Derived from $N$-Prolylsulfonamide for the Asymmetric Direct Aldol Reaction in Water. Organic Letters 8 (2006) 4417-4420.

228. S.G. Kim, T.H. Park, B.J. Kim. Efficient total synthesis of (+)-exo-, (-)-endobrevicomin and their derivatives via asymmetric organocatalysis and olefin crossmetathesis. Tetrahedron Letters 47 (2006) 6369-6372.

229. M. Lorin, R. Delepee, J.-C. Maurizot, J.P. Ribet, P. Morin. Sensitivity improvement of circular dichroism detection in HPLC by using a low-pass electronic noise filter: Application to the enantiomeric determination purity of a basic drug. Chirality 19 (2007) 106-113.

230. Y. Suto, M. Kanai, M. Shibasaki. Catalytic Enantioselective Mannich-type Reactions of Ketoimines. Journal of the American Chemical Society 129 (2007) 500-501.

231. C.A. Busacca, T. Bartholomeyzik, S. Cheekoori, N. Grinberg, H. Lee, S. Ma, A. Saha, S. Shen, C.H. Senanayake. On the Racemization of Chiral Imidazolines. The Journal of Organic Chemistry 73 (2008) 9756-9761.

232. R.R. Shaikh, A. Mazzanti, M. Petrini, G. Bartoli, P. Melchiorre. Proline-Catalyzed Asymmetric Formal $\alpha$-Alkylation of Aldehydes via Vinylogous Iminium Ion Intermediates Generated from Arylsulfonyl Indoles. Angewandte Chemie International Edition (English) 47 (2008) 8707-8710.

233. S.S. Chimni, S. Singh, D. Mahajan. Protonated $(S)$-prolinamide derivatives-water compatible organocatalysts for direct asymmetric aldol reaction. Tetrahedron: Asymmetry 19 (2008) 2276-2284.

234. T. Tsubogo, S. Saito, K. Seki, Y. Yamashita, S. Kobayashi. Development of Catalytic Asymmetric 1,4-Addition and [3 + 2] Cycloaddition Reactions Using Chiral Calcium Complexes. Journal of the American Chemical Society 130 (2008) 13321-13332.

235. D. Almasi, D.A. Alonso, E. Gomez-Bengoa, C. Najera. Chiral 2-Aminobenzimidazoles as Recoverable Organocatalysts for the Addition of 1,3-Dicarbonyl Compounds to Nitroalkenes. The Journal of Organic Chemistry 74 (2009) 6163-6168.

236. M.R. Vishnumaya, V.K. Singh. Highly Efficient Small Organic Molecules for Enantioselective Direct Aldol Reaction in Organic and Aqueous Media. The Journal of Organic Chemistry 74 (2009) 4289-4297.

237. H. Jiang, M.W. Paixao, D. Monge, K.A. Jorgensen. Acyl Phosphonates: Good Hydrogen Bond Acceptors and Ester/Amide Equivalents in Asymmetric Organocatalysis. Journal of the American Chemical Society 132 (2010) 2775-2783.

238. H.X. Guo, S. Wu, K. Nadeau, G.A. Moniz, S. Caille. Effects of solvent on chiral and enantiomeric separation of Koga bases using derivatized amylose chiral stationary phase. Chirality 22 (2010) 50-55.

239. A. Ghanem. True and false reversal of the elution order of barbiturates on a bonded cellulose-based chiral stationary phase.Journal of Chromatography A 1132 (2006) 329-332.

240. S. Caccamese, G. Scivoli, S. Bianca, J.M. Lopez-Romero, F.J. Ortiz-Lopez. Chiral highperformance liquid chromatographic separation and circular dichroism spectra of the enantiomers of cytotoxic aristocularine alkaloids. Journal of Chromatography $A$ 1129 (2006) 140-144.

241. G. Nadalini, F. Dondi, A. Massi, A. Dondoni, T. Zhang, A. Cavazzini. Highperformance liquid chromatographic separation of dihydropyrimidine racemates 
on polysaccharide-derived chiral stationary phases. Journal of Chromatography A 1126 (2006) 357-364.

242. J. Vachon, C. Lauper, K. Ditrich, J. Lacour. Enantioselective olefin epoxidation using novel biphenyl and binaphthyl azepines and azepinium salts. Tetrahedron: Asymmetry 17 (2006) 2334-2338.

243. A. Ghanem. Exploring solvent versatility in immobilized cellulose-based chiral stationary phase for the enantioselective liquid chromatographic resolution of racemates. Journal of Separation Science, 30 (2007) 1019-1028.

244. J.Y. Jin, W. Lee, J.H. Park, J.J. Ryoo. Liquid chromatographic enantiomer separation of N-phtaloyl protected a-amino acids on coated and immobilized chiral stationary phase derived from polysaccharide derivatives. Journal of Liquid Chromatography \& Related Technologies 30 (2007) 1-9.

245. P. Grundmann, W.-D. Fessner. One-Pot, Regioselective Synthesis of Substituted Arylglycines for Kinetic Resolution by Penicillin G Acylase. Advanced Synthesis and Catalysis 350 (2008) 1729-1735.

246. T. Zhang, D. Nguyen, P. Franco. Enantiomer resolution screening strategy using multiple immobilised polysaccharide-based chiral stationary phases. Journal of Chromatography A 1191 (2008) 214-222.

247. J.Y. Jin, S.K. Bae, W. Lee. Comparative studies between covalently immobilized and coated chiral stationary phases based on polysaccharide derivatives for enantiomer separation of $N$-protected $\alpha$-amino acids and their ester derivatives. Chirality 21 (2009) 871-877.

248. T. Saito, T. Kikuchi, H. Tanabe, J. Yahiro, T. Otani. Enantioselective synthesis of $\beta-$ lactams via the IndaBox-Cu(II)-catalyzed Kinugasa reaction. Tetrahedron Letters 50 (2009) 4969-4972.

249. A.V. Malkov, K. Vrankova, S. Stoncius, P. Kocovsky. Asymmetric Reduction of Imines with Trichlorosilane, Catalyzed by Sigamide, an Amino Acid-Derived Formamide: Scope and Limitations. The Journal of Organic Chemistry 74 (2009) 5839-5849.

250. A. Ghanem. Direct enantioselective HPLC monitoring of lipase-catalyzed kinetic resolution of flurbiprofen. Chirality 22 (2010) 597-603.

251. B.M. Trost, V.S. Chan, D. Yamamoto. Enantioselective ProPhenol-Catalyzed Addition of 1,3-Diynes to Aldehydes to Generate Synthetically Versatile Building Blocks and Diyne Natural Products. Journal of the American Chemical Society 132 (2010) 5186-5192.

252. A. Ghanem, H.Y. Aboul-Enein. On the solvent versatility in immobilized amylose tris(3,5-dimethylphenylcarbamate) chiral stationary phase in high performance liquid chromatography: Application to the asymmetric cyclopropanation of olefins. Analytica Chimica Acta 548 (2005) 26-32.

253. A. Ghanem, H.Y. Aboul-Enein. Comparison, applications, advantages, and limitations of immobilized and coated amylase tris-(3,5dimethylpheynlcarbamate) chiral stationary phases in HPLC. Journal of Liquid Chromatography \& Related Technologies 28 (2005) 2669-2680.

254. T. Zhang, C. Kientzy, P. Franco, A. Ohnishi, Y. Kagamihara, H. Kurosawa. Solvent versatility of immobilized 3,5-dimethylphenylcarbamate of amylose in enantiomeric separations by HPLC. Journal of Chromatography A 1075 (2005) 6575 . 
255. T. Kawasaki, K. Suzuki, E. Licandro, A. Bossi, S. Maiorana, K. Soai. Enantioselective synthesis induced by tetrathia-[7]-helicenes in conjunction with asymmetric autocatalysis. Tetrahedron: Asymmetry 17 (2006) 2050-2053.

256. H. Suga, T. Suzuki, K. Inoue, A. Kakehi. Asymmetric cycloaddition reactions between 2-benzopyrylium-4-olates and 3-(2-alkenoyl)-2-oxazolidinones in the presence of 2,6-bis(oxazolinyl)pyridine-lanthanoid complexes. Tetrahedron 62 (2006) 9218-9225.

257. P. Kasak, V.B. Arion, M. Widhalm. A chiral phosphepine-olefin rhodium complex as an efficient catalyst for the asymmetric conjugate addition. Tetrahedron: Asymmetry 17 (2006) 3084-3090.

258. A. Andersson, H. Nelander, K. Ohlen. Preparative chiral chromatography and chiroptical characterization of enantiomers of omeprazole and related benzimidazoles. Chirality 19 (2007) 706-715.

259. A. Ghanem, E. Al-Humaidi. Chiral recognition ability and solvent versatility of bonded amylose tris(3,5-dimethylphenylcarbamate) chiral stationary phase: Enantioselective liquid chromatographic resolution of racemic $\mathrm{N}$-alkylated barbiturates and thalidomide analogs. Chirality 19 (2007) 477-484.

260. B. Saito, H. Egami, T. Katsuki. Synthesis of an Optically Active Al(salalen) Complex and Its Application to Catalytic Hydrophosphonylation of Aldehydes and Aldimines. Journal of the American Chemical Society 129 (2007) 1978-1986.

261. R. Cirilli, R. Ferretti, E. De Santis, B. Gallinella, L. Zanitti, F. La Torre. Highperformance liquid chromatography separation of enantiomers of flavanone and 2'-hydroxychalcone under reversed-phase conditions. Journal of Chromatography A 1190 (2008) 95-101.

262. J. Shen, C.-H. Tan. Anthrone-derived NHPI analogues as catalysts in reactions using oxygen as an oxidant. Organic and Biomolecular Chemistry 6 (2008) 4096-4098.

263. C.M. Reisinger, X. Wang, B. List. Catalytic Asymmetric Hydroperoxidation of $\alpha, \beta-$ Unsaturated Ketones: An Approach to Enantiopure Peroxyhemiketals, Epoxides, and Aldols. Angewandte Chemie International Edition (English) 47 (2008) 81128115.

264. S. Shirakawa, T. Kimura, S.-I. Murata, S. Shimizu. Synthesis and Resolution of a Multifunctional Inherently Chiral Calix[4]arene with an ABCD Substitution Pattern at the Wide Rim: The Effect of a Multifunctional Structure in the Organocatalyst on Enantioselectivity in Asymmetric Reactions. The Journal of Organic Chemistry 74 (2009) 1288-1296.

265. S.L. Poe, A.R. Bogdan, B.P. Mason, J.L. Steinbacher, S.M. Opalka, D.T. McQuade. Use of Bifunctional Ureas to Increase the Rate of Proline-Catalyzed $\alpha$-Aminoxylations. The Journal of Organic Chemistry 74 (2009) 1574-1580.

266. A. Ciogli, W. Bicker, W. Lindner. Determination of enantiomerization barriers of hypericin and pseudohypericin by dynamic high-performance liquid chromatography on immobilized polysaccharide-type chiral stationary phases and off-column racemization experiments. Chirality 22 (2010) 463-471.

267. T. Hashimoto, Y. Maeda, M. Omote, H. Nakatsu, K. Maruoka. Catalytic Enantioselective 1,3-Dipolar Cycloaddition of $\mathrm{C}, \mathrm{N}$-Cyclic Azomethine Imines with $\alpha, \beta$-Unsaturated Aldehydes. Journal of the American Chemical Society 132 (2010) 4076-4077. 
268. H.Y. Aboul-Enein, I. Ali, Chiral separation by liquid chromatography and related Technologies, Marcel Dekker, Inc. New York, 2003, p. 21.

269. G. Fogassy, A. Tungler, A. Lévai, G. Toth. Enantioselective hydrogenation of exocyclic $\alpha, \beta$-unsaturated ketones: Part II. Hydrogenation in the presence of $(S)$ proline. Journal of Molecular Catalysis A: Chemical 179 (2002) 101-106.

270. M. Garzotti, M. Hamdan. Supercritical fluid chromatography coupled to electrospray mass spectrometry: a powerful tool for the analysis of chiral mixtures. Journal of Chromatography B $\mathbf{7 7 0}$ (2002) 53-61.

271. M.E. Andersson, D. Aslan, A. Clarke, J. Roeraade, G. Hagman. Evaluation of generic chiral liquid chromatography screens for pharmaceutical analysis. Journal of Chromatography A 1005 (2003) 83-101.

272. M.X. Wang, G.Q. Feng. Nitrile Biotransformation for Highly Enantioselective Synthesis of 3-Substituted 2,2-Dimethylcyclopropanecarboxylic Acids and Amides. The Journal of Organic Chemistry 68 (2003) 621-624.

273. Z. Tang, F. Jiang, X. Cui, L.-Z. Gong, A.-Q. Mi, Y.-Z. Jiang, Y.-D. Wu. Asymmetric Catalysis Special Feature Part II: Enantioselective direct aldol reactions catalyzed by L-prolinamide derivatives. Proceedings of the National Academy of Sciences of the USA 101 (2004) 5755-5760.

274. H. Guo, X. Wang, K. Ding. Assembled enantioselective catalysis for carbonyl-ene reactions. Tetrahedron Letters 45 (2004) 2009-2012.

275. N. Kato, S. Shimamura, S. Khan, F. Takeda, Y. Kikai, M. Hirama. Convergent approach to the maduropeptin chromophore: aryl ether formation of $(R)$-3-aryl-3hydroxypropanamide and cyclization of macrolactam. Tetrahedron 60 (2004) 3161-3172.

276. Q. Fan, L. Lin, J. Liu, Y. Huang, X. Feng. A Mild and Efficient Asymmetric HeteroDiels-Alder Reaction of the Brassard Diene with Aldehydes. European Journal of Organic Chemistry 2005 (2005) 3542-3552.

277. M. Nakajima, S. Kotani, T. Ishizuka, S. Hashimoto. Chiral phosphine oxide BINAPO as a catalyst for enantioselective allylation of aldehydes with allyltrichlorosilanes. Tetrahedron Letters 46 (2005) 157-159.

278. M. Marigo, T. Schulte, J. Franzen, K.A. Jorgensen. Asymmetric Multicomponent Domino Reactions and Highly Enantioselective Conjugated Addition of Thiols to $\alpha, \beta$-Unsaturated Aldehydes. Journal of the American Chemical Society 127 (2005) 15710-15711.

279. Q. Yang, G. Shang, W. Gao, J. Deng, X. Zhang. A highly enantioselective, PdTangPhos-catalyzed hydrogenation of N-Tosylimines. Angewandte Chemie International Edition (English) 45 (2006) 3822-3835.

280. J. Xu, Y. Guan, S. Yang, Y. Ng, G. Peh, C.H. Tan. Asymmetric Baylis-Hillman Reactions Promoted by Chiral Imidazolines. Chemistry - An Asian Journal 1 (2006) 724-729.

281. C. Chen, S.F. Zhu, X.Y. Wu, Q.L. Zhou. Preparation and application of chiral spiro nitrogen-containing ligands for cobalt-caralyzed asymmetric Michael addition. Tetrahedron: Asymmetry 17 (2006) 2761-2767.

282. S. Kotani, S. Hashimoto, M. Nakajima. Chiral phosphine oxide BINAPO as a Lewis base catalyst for asymmetric allylation and aldol reaction of trichlorosilyl compounds. Tetrahedron 63 (2007) 3122-3132. 
283. T.B. Poulsen, L. Bernardi, J. Aleman, J. Overgaard, K.A. Jorgensen. Organocatalytic Asymmetric Direct $\alpha$-Alkynylation of Cyclic $\beta$-Ketoesters. Journal of the American Chemical Society 129 (2007) 441-449.

284. N. Byrne, E. Hayes-Larson, W.-W. Liao, C.M. Kraml. Analysis and purification of alcohol-sensitive chiral compounds using 2,2,2-trifluoroethanol as a modifier in supercritical fluid chromatography. Journal of Chromatography B 875 (2008) 237242.

285. M. Tokizane, K. Sato, T. Ohta, Y. Ito. Asymmetric reduction of racemic 2isoxazolines. Tetrahedron: Asymmetry 19 (2008) 2519-2528.

286. G.-S. Liu, Q.-L. Dong, Y.-S. Yao, Z.-J. Yao. Expeditious total syntheses of camptothecin and 10-hydroxycamtothecin. Organic Letters 10 (2008) 5393-5396.

287. K. Murayama, T. Tanabe, Y. Ishikawa, K. Nakamura, S. Nishiyama. A synthetic study on gymnastatins $\mathrm{F}$ and $\mathrm{Q}$ : the tandem Michael and aldol reaction approach. Tetrahedron Letters 50 (2009) 3191-3194.

288. N. Tosa, A. Bende, R.A. Varga, A. Terec, I. Bratu, I. Grosu. H-Bond-Driven Supramolecular Architectures of the Syn and Anti Isomers of the Dioxime of Bicyclo[3.3.1]nonane-3,7-dione. The Journal of Organic Chemistry 74 (2009) 39443947.

289. P. Fang, X.-L. Hou. Asymmetric Copper-Catalyzed Propargylic Substitution Reaction of Propargylic Acetates with Enamines. Organic Letters 11 (2009) 4612-4615.

290. T. Kubota, N. Sawada, L. Zhou, C.J. Welch. Enantioseparation of benzazoles and benzanilides on polysaccharide-based chiral columns. Chirality 22 (2010) 382-388.

291. C. Wang, G. Yang, J. Zhuang, W. Zhang. From tropos to atropos: 5,5'-bridged 2,2'bis(diphenylphosphino)biphenyls as chiral ligands for highly enantioselective palladium-catalyzed hydrogenation of $\alpha$-phthalimide ketones. Tetrahedron Letters 51 (2010) 2044-2047.

292. Z. Weng, J. Li. Synthesis and antidepressant activity of optical isomers of 2-(4benzylpiperazin-1-yl)-1-(5-chloro-6-methoxynaphthalen-2-yl) propan-1-ol (SIPI5056). Bioorganic and Medicinal Chemistry Letters 20 (2010) 1256-1259.

293. A. Natarajan, K. Wang, V. Ramamurthy, J.R. Scheffer, B. Patrick. Control of Enantioselectivity in the Photochemical Conversion of $\alpha$-Oxoamides into $\beta$-Lactam Derivatives. Organic Letters 4 (2002) 1443-1446.

294. D.J. Spielvogel, S.L. Buchwald. Nickel-BINAP Catalyzed Enantioselective $\alpha$-Arylation of $\alpha$-Substituted $\gamma$-Butyrolactones. Journal of the American Chemical Society 124 (2002) 3500-3501.

295. C.Y. Chang, T.K. Yang. Asymmetric synthesis of ACE inhibitor Benazepril HCl via a bioreductive reaction. Tetrahedron: Asymmetry 14 (2003) 2239-2245.

296. K. Kuramochi, S. Nagata, H. Itaya, Y. Matsubarta, T. Sunoki, H. Uchiro, K.I. Takao, S. Kobayashi. A convergent total synthesis of epolactaene: an application of the bridgehead oxiranyl anion strategy. Tetrahedron 59 (2003) 9743-9758.

297. S. Ma, F. Yu, W. Gao. Studies on Pd(II)-Catalyzed Coupling-Cyclization of $\alpha$ - or $\beta$ Amino Allenes with Allylic Halides. The Journal of Organic Chemistry 68 (2003) 5943-5949.

298. Y. Yuasa, H. Tsuruta. Enantioselective synthesis of $(S)$-3-(4-thiazolyl)-2-tertbutoxycarbonylaminopropionic acid: A chiral building block for renin inhibitor. Heterocycles 63 (2004) 2385-2392. 
299. Z. Zhang, G. Yang, G. Liang, H. Liu, Y. Chen. Chiral separation of Tamsulosin isomers by HPLC using cellulose Tris (3,5-dimethhylphenylcarbamate) as a chiral stationary phase. Journal of Pharmaceutical and Biomedical Analysis 34 (2004) 689-693.

300. B.M. Trost, J. Xu. Palladium-Catalyzed Asymmetric Allylic $\alpha$-Alkylation of Acyclic Ketones. Journal of the American Chemical Society 127 (2005) 17180-17181.

301. Y.K. Ye, R.W. Stringham. The effect of acidic and basic additives on the enantioseparation of basic drugs using polysaccharide-based chiral stationary phases. Chirality 18 (2006) 519-530.

302. Y.X. Chang, L.M. Yuan, F. Zhao. Effect of Chiral Additives in the Preparation of Cellulose-Based Chiral Stationary Phases in HPLC, and Effect on Enantiomer Resolution. Chromatographia 64 (2006) 313-316.

303. K. Kato, C. Matsuba, T. Kusakabe, H. Takayama, S. Yamamura, T. Mochida, H. Akita, T.A. Peganova, N.V. Vologdin, O.V. Gusev. 2,2'-Isopropylidenebis[(4S,5R)-4,5-di(2naphthyl)-2-oxazoline] ligand for asymmetric cyclization-carbonylation of meso-2alkyl-2-propargylcyclohexane-1,3-diols. Tetrahedron 62 (2006) 9988-9999.

304. C. Roussel, N. Vanthuyne, J.L. Jobert, A. Loas, A.E. Tanase, D. Gherase. HPLC on chiral support with polarimetric detection: Application to conglomerate discovery. Chirality 19 (2007) 497-502.

305. B.M. Trost, J. Xu, M. Reichle. Enantioselective Synthesis of $\alpha$-Tertiary Hydroxyaldehydes by Palladium-Catalyzed Asymmetric Allylic Alkylation of Enolates. Journal of the American Chemical Society 129 (2007) 282-283.

306. B.M. Trost, J. Xu, T. Schmidt. Ligand Controlled Highly Regio- and Enantioselective Synthesis of $\alpha$-Acyloxyketones by Palladium-Catalyzed Allylic Alkylation of 1,2Enediol Carbonates. Journal of the American Chemical Society 130 (2008) 1185211853.

307. R. Csuk, B. Woeste. A chemoenzymatic approach to (+)-pilocarpine. Tetrahedron 64 (2008) 9384-9387.

308. C. Roussel, N. Vanthuyne, M. Bouchekara, A. Djafri, J. Elguero, I. Alkorta. Atropisomerism in the 2-Arylimino- $N$-(2-hydroxyphenyl)thiazoline Series: Influence of Hydrogen Bonding on the Racemization Process. The Journal of Organic Chemistry 73 (2008) 403-411.

309. J.-G. Kim, D.O. Jang. Trifluoroacetylation of amines with trifluoroacetic acid in the presence of trichloroacetonitrile and triphenylphosphine. Tetrahedron Letters $\mathbf{5 1}$ (2010) 683-685.

310. M.A. Andersson, R. Epple, V.V. Fokin, K.B. Sharpless. A New Approach to OsmiumCatalyzed Asymmetric Dihydroxylation and Aminohydroxylation of Olefins. Angewandte Chemie International Edition (English) 41 (2002) 472-475.

311. Y. Okumura, A. Ando, R.W. Stevens, M. Shimizu. Efficient and practical synthesis of both enantiomers of 3-phenylcyclopentanol derivatives. Tetrahedron 58 (2002) 8729-8736.

312. M. Ogasawara, K. Ueyama, T. Nagano, Y. Mizuhata, T. Hayashi. Palladium-Catalyzed Asymmetric Synthesis of Axially Chiral (Allenylmethyl)silanes and Chirality Transfer to Stereogenic Carbon Centers in $\mathrm{S}_{\mathrm{E}}{ }^{\prime}$ Reactions. Organic Letters 5 (2003) 217-219. 
313. F.J.M. de Santana, E.J. Cesarino, P.S. Bonato. New method for the chiral evaluation of mirtazapine in human plasma by liquid chromatography. Journal of Chromatography B 809 (2004) 351-356.

314. N. Aoyagi, S. Kawauchi, T. Izumi. Different recognitions of $(E)$ - and $(Z)-1,1^{\prime}-$ binaphthyl ketoximes using lipase-catalyzed reactions. Tetrahedron Letters 45 (2004) 5189-5192.

315. B.H. Kim, S.U. Lee. Enantiomer Separation of a Novel Aminothiazolecarboxamide Fungicide Using Polysaccharide-Derived Chiral Stationary Phases. Journal of Chromatography Science 43 (2005) 501-504.

316. R. Shintani, W.-L. Duan, T. Nagano, A. Okada, T. Hayashi. Chiral Phosphine-Olefin Bidentate Ligands in Asymmetric Catalysis: Rhodium-Catalyzed Asymmetric 1,4Addition of Aryl Boronic Acids to Maleimides. Angewandte Chemie International Edition (English) 44 (2005) 4611-4614.

317. N. Aoyagi, N. Ogawa, T. Izumi. Effects of reaction temperature and acyl group for lipase-catalyzed chiral binaphthol synthesis. Tetrahedron Letters 47 (2006) 47974801.

318. L. Cheng, L. Liu, D. Wang, Y.-J. Chen. Highly enantioselective and organocatalytic $\alpha-$ amination of 2-oxindoles. Organic Letters 11 (2009) 3874-3877.

319. T. Nishimura, J. Wang, M. Nagaosa, K. Okamoto, R. Shintani, F. Kwong, W. Yu, A.S.C. Chan, T. Hayashi. Rhodium-Catalyzed Asymmetric Addition of Arylboronic Acids to $\beta$-Phthaliminoacrylate Esters toward the Synthesis of $\beta$-Amino Acids. Journal of the American Chemical Society 132 (2010) 464-465.

320. H.Y. Aboul-Enein, I. Ali. Comparative study of the enantiomeric resolution of chiral antifungal drugs econazole, miconazole and sulconazole by HPLC on various cellulose chiral columns in normal phase mode. Journal of Pharmaceutical and Biomedical Analysis 27 (2002) 441-446.

321. J.H. Smitrovich, G.N. Boice, C. Qu, L. DiMichele, T.D. Nelson, M.A. Huffman, J. Murry, J. McNamara, P.J. Reider. Pseudoephedrine as a Chiral Auxiliary for Asymmetric Michael Reactions: Synthesis of 3-Aryl- $\delta$-lactones. Organic Letters 4 (2002) 19631966.

322. R. Kuwano, K.I. Uchida, Y. Ito. Asymmetric Allylation of Unsymmetrical 1,3Diketones Using a BINAP-Palladium Catalyst. Organic Letters 5 (2003) 2177-2179.

323. B. Zajc, R. Grahek, A. Kocijan, M.K. Lakshman, J. Kosmrlj, J. Lah. Evaluation of the Enantiomeric Resolution of 7,8-Dihydroxy-7,8-dihydrobenzo[a]- pyrene and Its 6Fluoro and 6-Bromo Derivatives on Polysaccharide-Derived Stationary Phase. The Journal of Organic Chemistry 68 (2003) 3291-3294.

324. T.D. Nelson, C.J. Welch, J.D. Rosen, J.H. Smitrovich, M.A. Huffman, J.M. McNamara, D.J. Mathre. Effective use of preparative chiral HPLC in a preclinical drug synthesis. Chirality 16 (2004) 609-613.

325. M. Bandini, P.G. Cozzi, P. Melchiorre, A. Umani-Ronchi. Kinetic Resolution of Epoxides by a C-C Bond-Forming Reaction: Highly Enantioselective Addition of Indoles to cis, trans, and meso Aromatic Epoxides Catalyzed by $[\mathrm{Cr}(\mathrm{salen})]$ Complexes. Angewandte Chemie International Edition (English) 43 (2004) 84-87.

326. M. Bandini, A. Garelli, M. Rovinetti, S. Tommasi, A. Umani-Ronchi. Catalytic enantioselective addition of indoles to arylnitroalkenes: An effective route to enantiomerically enriched tryptamine precursors. Chirality 17 (2005) 522-529. 
327. K. Inoue, Y. Makino, N. Itoh. Production of $(R)$-chiral alcohols by a hydrogentransfer bioreduction with NADH-dependent Leifsonia alcohol dehydrogenase (LSADH). Tetrahedron: Asymmetry 16 (2005) 2539-2549.

328. P.G. Cozzi, P. Kotrusz. Highly Enantioselective Addition of $\mathrm{Me}_{2} \mathrm{Zn}$ to Aldehydes Catalyzed by $\mathrm{ClCr}($ Salen). Journal of the American Chemical Society 128 (2006) 4940-4941.

329. L. Deng, H. Nakano, Y. Iwasaki. Direct separation of monoacylglycerol isomers by enantioselective high-performance liquid chromatography. Journal of Chromatography A 1198-1199 (2008) 67-72.

330. D. Leow, S. Lin, S.K. Chittimalla, X. Fu, C.-H. Tan. Enantioselective Protonation Catalyzed by a Chiral Bicyclic Guanidine Derivative. Angewandte Chemie International Edition (English) 47 (2008) 5641-5645.

331. V. Jurkauskas, S.L. Buchwald. Dynamic Kinetic Resolution via Asymmetric Conjugate Reduction: Enantio- and Diastereoselective Synthesis of 2,4-Dialkyl Cyclopentanones. Journal of the American Chemical Society 124 (2002) 2892-2893.

332. S. Ye, Z.Z. Huang, C.A. Xia, Y. Tang, L.X. Dai. A Novel Chiral Sulfonium Yilde: Highly Enantioselective Synthesis of Vinylcyclopropanes. Journal of the American Chemical Society 124 (2002) 2432-2433.

333. O. Azzolina, S. Collina, G. Brusotti, D. Rossi, A. Callegari, L. Linati, A. Barbieri, V. Ghislandi. Chemical and biological profile of racemic and optically active dialkylaminoalkylnaphthalenes with analgesic activity. Tetrahedron: Asymmetry 13 (2002) 1073-1081.

334. A. Kamal, M. Sandbhor, A.A. Shaik, V. Sravanthi. One-pot synthesis and resolution of chiral allylic alcohols. Tetrahedron: Asymmetry 14 (2003) 2839-2844.

335. M. Benaglia, M. Cinquini, F. Cozzi, A. Puglisi, G. Celentano. Poly(ethylene-glycol)supported proline: a recyclable aminocatalyst for the enantioselective synthesis of $\gamma$-nitroketones by conjugate addition. Journal of Molecular Catalysis A: Chemical (2003) 204-205.

336. C.A. Sandoval, T. Ohkuma, K. Muniz, R. Noyori. Mechanism of Asymmetric Hydrogenation of Ketones Catalyzed by BINAP/1,2-Diamine-Ruthenium(II) Complexes. Journal of the American Chemical Society 125 (2003) 13490-13503.

337. V. Pironti, S. Nicolis, E. Monzani, S. Colonna, L. Casella. Nitrite increases the enantioselectivity of sulfoxidation catalyzed by myoglobin derivatives in the presence of hydrogen peroxide. Tetrahedron 60 (2004) 8153-8160.

338. Y.G. Li, Q.S. Tian, J. Zhao, Y. Feng, M.J. Li, T.P. You. Asymmetric pinacol coupling of aromatic aldehydes caralyzed by a new titanium-Schiff base complex. Tetrahedron: Asymmetry 15 (2004) 1707-1710.

339. K. Micskei, C. Hajdu, L.A. Wessjohann, L. Mercs, A. Kiss-Szikszai, T. Patonay. Enentioselective reduction of prochiral ketones by chromium(II) amino acid complexes. Tetrahedron: Asymmetry 15 (2004) 1735-1744.

340. J.C. Kizirian, N. Cabello, L. Pinchard, J.C. Caille, A. Alexakis. Enantioselective addition of methyllithium to aromatic imines catalyzed by $C_{2}$ symmetric tertiary diamines. Tetrahedron 61 (2005) 8939-8946.

341. R.B. Bedford, M. Betham, M.E. Blake, A. Garces, S.L. Millar, S. Prashar. Asymmetric styrene dimerisation using mixed palladium-indium catalysts. Tetrahedron $\mathbf{6 1}$ (2005) 9799-9807. 
342. H.F. Duan, J.H. Xie, W.J. Shi, Q. Zhang, Q.L. Zhou. Enantioselective RhodiumCatalyzed Addition of Arylboronic Acids to Aldehydes Using Chiral Spiro Monophosphite Ligands. Organic Letters 8 (2006) 1479-1481.

343. J.V. Naubron, L. Giordano, F. Fotiadu, T. Burgi, N. Vanthuyne, C. Roussel, G. Buono. Chromatographic Resolution, Solution and Crystal Phase Conformations, and Absolute Configuration of tert-Butyl(dimethylamino)phenylphosphine-Borane Complex. The Journal of Organic Chemistry 71 (2006) 5586-5593.

344. S.S. Kim, S.H. Lee, J.M. Kwak. Enantioselective cyanosilylation of ketones catalyzed by $\mathrm{Mn}$ (salen)/ $\mathrm{Ph}_{3} \mathrm{PO}$. Tetrahedron: Asymmetry 17 (2006) 1165-1169.

345. S. Liu, C. Wolf. Chiral Amplification Based on Enantioselective Dual-Phase Distribution of a Scalemic Bisoxazolidine Catalyst. Organic Letters 9 (2007) 29652968.

346. H.K. Luo, H.Y. Yang, T.X. Jie, O.S. Chiew, H. Schumann, L.B. Khim, C. Lim. Watertolerant enantioselective carbonyl-ene reactions with palladium(II) and platinum(II) Lewis acid catalysts bearing BINAP. Journal of Molecular Catalysis A: Chemical 261 (2007) 112-119.

347. Y. Kobayashi, K. Soetrisno, K. Kodama, K. Saigo. Enantioselective inclusion of chiral alkyl aryl sulfoxides in a supramolecular helical channel consisting of an enantiopure 1,2-amino alcohol and an achiral carboxylic acid. Tetrahedron: Asymmetry 19 (2008) 295-301.

348. X. Liao, Z. Weng, J.F. Hartwig. Enantioselective $\alpha$-Arylation of Ketones with Aryl Triflates Catalyzed by Difluorphos Complexes of Palladium and Nickel. Journal of the American Chemical Society 130 (2008) 195-200.

349. Y. Sohtome, N. Takemura, R. Takagi, Y. Hashimoto, K. Nagasawa. Thioureacatalyzed Morita-Baylis-Hillman reaction. Tetrahedron 64 (2008) 9423-9429.

350. S. Facchetti, I. Cavallini, T. Funaioli, F. Marchetti, A. Iuliano. Tropos Ligands in Asymmetric Rhodium(I)-Catalyzed Addition of Arylboronic Acids to Enones: How a Tunable Coordination Gives Different Reaction Products. Organometallics 28 (2009) 4150-4158.

351. M. Szaleniec, A. Dudzik, M. Pawul, B. Kozik. Quantitative structure enantioselective retention relationship for high-performance liquid chromatography chiral separation of 1-phenylethanol derivatives. Journal of Chromatography A 1216 (2009) 6224-6235.

352. L.L. Machado, G. de Gonzalo, T.L.G. Lemos, M.C. de Mattos, M.C.F. de Oliveira, V. Gotor-Fernández, V. Gotor. Enantioselective acetylation or racemic alcohols by Manihot esculenta and Passiflora edulis preparations. Journal of Molecular Catalysis B: Enzymatic. 60 (2009) 157-162.

353. Y.J. Zhang, J.H. Yang, S.H. Kim, M.J. Krische. anti-Diastereo- and Enantioselective Carbonyl (Hydroxymethyl)allylation from the Alcohol or Aldehyde Oxidation Level: Allyl Carbonates as Allylmetal Surrogates. Journal of the American Chemical Society 132 (2010) 4562-4563.

354. T. Seiser, N. Cramer. Rhodium-Catalyzed C-C Bond Cleavage: Construction of Acyclic Methyl Substituted Quaternary Stereogenic Centers. Journal of the American Chemical Society 132 (2010) 5340-5341.

355. F. Meyer, A. Laaziri, A.M. Papini, J. Uziel, S. Jugé. Efficient synthesis of $\beta$-halogeno protected L-alanines and their $\beta$-phosphonium derivatives. Tetrahedron: Asymmetry 14 (2003) 2229-2238. 
356. S.I. Ueji, T. Taniguchi, T. Okamoto, K. Watanabe, Y. Ebara, H. Ohta. Flexibility of Lipase Brought About by Solvent Effects Controls Its Enantioselectivity in Organic Media. Bulletin of the Chemical Society of Japan 76 (2003) 399-403.

357. C. Bauduin, D. Moulin, E.B. Kaloun, C. Darcel, S. Juge. Highly Enantiomerically Enriched Chlorophosphine Boranes: Synthesis and Applications as P-Chirogenic Electrophilic Blocks. The Journal of Organic Chemistry 68 (2003) 4293-4301.

358. M.X. Wang, Y. Wu. Nitrile biotransformations for the synthesis of enantiomerically enriched Baylis-Hillman aducts. Organic and Biomolecular Chemistry 1 (2003) 535540 .

359. S. Mori, H. Yumoto, R. Matsumi, T. Nishigaki, Y. Ebara, S. Ueji. A method to greatly improve the enantioselectivity of lipase-catalyzed hydrolysis using sodium dodecyl sulfate (SDS) as an additive. Tetrahedron: Asymmetry 16 (2005) 3698-3702.

360. H.A. Wetli, E. Francotte. Automated screening platform with isochronal-parallel analysis and conditioning for rapid method development of chiral separation. Journal of Separation Science 30 (2007) 1255-1261.

361. Y. Hayashi, T. Itoh, S. Aratake, H. Ishikawa. A Diarylprolinol in an Asymmetric, Catalytic, and Direct Crossed-Aldol Reaction of Acetaldehyde. Angewandte Chemie International Edition (English) 47 (2008) 2082-2084.

362. D. Hazelard, H. Ishikawa, D. Hashizume, H. Koshino, Y. Hayashi. Proline-Mediated Enantioselective Construction of Tetrahydropyrans via a Domino Aldol/Acetalization Reaction. Organic Letters 10 (2008) 1445-1448.

363. H.A. Kennedy, S. Vietrich, H. Weinmann, D.E.A. Brittain. Synthesis of 7a-Substituted Hajos-Wiechert Ketone Analogues. The Journal of Organic Chemistry 73 (2008) 5151-5154.

364. S. Zhu, S. Yu, D. Ma. Highly Efficient Catalytic System for Enantioselective Michael Addition of Aldehydes to Nitroalkenes in Water. Angewandte Chemie International Edition (English) 47 (2008) 545-548.

365. R. Ferretti, B. Gallinella, F. La Torre, L. Zanitti, L. Turchetto, A. Mosca, R. Cirilli. Direct high-performance liquid chromatography enantioseparation of terazosin on an immobilised polysaccharide-based chiral stationary phase under polar organic and reversed-phase conditions. Journal of Chromatography A 1216 (2009) 53855390.

366. Y. Wang, G. Arsenault, N. Riddell, R. McCrindle, A. McAlees, J.W. Martin. Perfluorooctane Sulfonate (PFOS) Precursors Can Be Metabolized Enantioselectively: Principle for a New PFOS Source Tracking Tool. Environmental Science and Technology 43 (2009) 8283-8289.

367. J.S. Yadav, C.S. Reddy. Stereoselective synthesis of amphidinolide T1. Organic Letters 11 (2009) 1705-1708.

368. T. Zhang, D. Nguyen, P. Franco. Reversed-phase screening strategies for liquid chromatography on polysaccharide-derived chiral stationary phases. Journal of Chromatography A 1217 (2010) 1048-1055.

369. Z. Zheng, B.L. Perkins, B. Ni. Diarylprolinol Silyl Ether Salts as New, Efficient, Water-Soluble, and Recyclable Organocatalysts for the Asymmetric Michael Addition on Water. Journal of the American Chemical Society 132 (2010) 50-51. 
370. B.-F. Shi, Y.-H. Zhang, J.K. Lam, D.-H. Wang, J.-Q. Yu. Pd(II)-Catalyzed Enantioselective C-H Olefination of Diphenylacetic Acids. Journal of the American Chemical Society 132 (2010) 460-461.

371. S. Ishikawa, F. Noguchi, H. Uno, A. Kamimura. Intramolecular Pauson-Khand reaction of optically active aza-Baylis-Hillman adducts. Tetrahedron Letters $\mathbf{5 1}$ (2010) 2329-2331.

372. A. Nakamura, S. Lectard, D. Hashizume, Y. Hamashima, M. Sodeoka. Diastereo- and Enantioselective Conjugate Addition of $\alpha$-Ketoesters to Nitroalkenes Catalyzed by a Chiral $\mathrm{Ni}(\mathrm{OAc})_{2}$ Complex under Mild Conditions. Journal of the American Chemical Society 132 (2010) 4036-4037.

373. D. Guieysse, C. Salagnad, P. Monsan, M. Remaud-Simeon. Lipase-catalysed enentioselective transesterification toward esters of 2-bromo-tolylacetic acids. Tetrahedron: Asymmetry 14 (2003) 317-323.

374. H. Jin, Z.Y. Li, X.W. Dong. Enantioselective hydrolysis of various substituted styrene oxides with Aspergillus Niger CGMCC 0496. Organic and Biomolecular Chemistry 2 (2004) 408-414.

375. G. Zhong, Y. Yu. Enantioselective Synthesis of Allylic Alcohols by the Sequential Aminoxylation-Olefination Reactions of Aldehydes under Ambient Conditions. Organic Letters 6 (2004) 1637-1639.

376. R. Kino, K. Daikai, T. Kawanami, H. Furuno, J. Inanaga. Remarkable effect of tris(4fluorophenyl)phosphine oxide on the stabilization of chiral lanthanum complex catalysts. A new and practical protocol for the highly enantioselective epoxidation of conjugated enones. Organic and Biomolecular Chemistry 2 (2004) 1822-1824.

377. K. Matsui, S. Takizawa, H. Sasai. Enantioselective Morita-Baylis-Hillman (MBH) reaction promoted by a heterobimetallic complex with a Lewis base. Tetrahedron Letters 46 (2005) 1943-1946.

378. F. Foubelo, B. Moreno, T. Soler, M. Yus. Reductive ring opening of dihydrodibenzothiepine and dihydrodinaphtho-oxepine and -thiepine. Tetrahedron 61 (2005) 9082-9096.

379. M. Shi, J.W. Shi. Chiral thiophosphoramide and selenophosphoramide ligands in the $\mathrm{Cu}(\mathrm{I})$-promoted catalytic enantioselective 1,3-dipolar cycloaddition reactions of azomethine ylides and pyrrole-2,5-dione derivatives. Tetrahedron: Asymmetry 18 (2007) 645-650.

380. C. Wang, X. Wu, L. Zhou, J. Sun. A Highly Enantioselective Organocatalytic Method for Reduction of Aromatic $N$-Alkyl Ketimines. Chemistry - A European Journal 14 (2008) 8789-8792.

381. E. Lipka, C. Vaccher, J.P. Bonte. Enantioseparation of benzoxazolinone aminoalcohols and their aminoketone precursors, potential adrenergic ligands, by analytical and preparative liquid chromatography on amylose chiral stationary phases and characterization of the enantiomers. Chirality 21 (2009) 769-776.

382. P. Krumlinde, K. Bogar, J.-E. Bäckvall. Synthesis of a Neonicotinoide Pesticide Derivative via Chemoenzymatic Dynamic Kinetic Resolution. The Journal of Organic Chemistry 74 (2009) 7407-7410.

383. X. Jiang, Y. Zhang, X. Liu, G. Zhang, L. Lai, L. Wu, J. Zhang, R. Wang. Enantio- and Diastereoselective Asymmetric Addition of 1,3-Dicarbonyl Compounds to Nitroalkenes in a Doubly Stereocontrolled Manner Catalyzed by Bifunctional 
Rosin-Derived Amine Thiourea Catalysts. The Journal of Organic Chemistry 74 (2009) 5562-5567.

384. F. Dong, X. Liu, Y. Zheng, Q. Cao, C. Li. Stereoselective degradation of fungicide triadimenol in cucumber plants. Chirality 22 (2010) 292-298.

385. R. Yazaki, N. Kumagai, M. Shibasaki. Direct Catalytic Asymmetric Addition of Allyl Cyanide to Ketones via Soft Lewis Acid/Hard Brønsted Base/Hard Lewis Base Catalysis. Journal of the American Chemical Society 132 (2010) 5522-5531.

386. D.L. Boger. Vancomycin, Teicoplanin and Ramoplanin Synthetic and mechanistic studies. Medicinal Research Reviews 21 (2001) 356-381.

387. K.H. Ekborg-Ott, L. Youbang, D.W. Armstrong. High enantioselective HPLC separations using the covalent bonded macrocyclic antibiotic, Ristocetin A, Chiral stationary phase. Chirality 10 (1998) 434-483.

388. P.J. Loll, P.H. Axelsen. The structural biology of molecular recognition by vancomycin. Annual Review of Biophysics and Biomolecular Structure 29 (2000) 265-289.

389. Y. Liu, A.W. Lantz, D.W. Armstrong. High efficiency liquid and super-/subcritical fluid-based enantiomeric separation: an overview. Journal of Liquid Chromatography \& Related Technologies 27 (2005) 1121-1178.

390. G. Boatto, M. Nieddu, M.V. Faedda, P. De Caprariis. Enantiomeric separation by HPLC of 1,4-dihydropyridines with vancomycin as chiral selector. Chirality 15 (2003) 494-497.

391. K. Pihlainen, R. Kostiainen. Effect of the eluent on enantiomer separation of controlled drugs by liquid chromatography-ultraviolet absorbance detectionelectrospray ionisation tandem mass spectrometry using vancomycin and native $\beta$ cyclodextrin chiral stationary phases. Journal of Chromatography A 1033 (2004) 91-99.

392. R. Patel, L. Chu, V. Nanduri, J. Li, A. Kotnis, W. Parker, M. Liu, R. Mueller. Enantioselective microbial reduction of 6-oxo-8-[4-[4-(2-pyrimidinyl)-1piperazinyl]butyl]-8-azaspiro[4.5]decane-7,9-dione. Tetrahedron: Asymmetry 16 (2005) 2778-2783.

393. R. Berkecz, R. Torok, I. Ilisz, E. Forro, F. Fulop, D.W. Armstrong, A. Peter. LC Enantioseparation of $\beta$-Lactam and $\beta$-Amino Acid Stereoisomers and a Comparison of Macrocyclic Glycopeptide- and $\beta$-Cyclodextrin-Based Columns. Chromatographia 63 (2006) S37-S43.

394. Y. Zhang, C. Holliman, D. Tang, D. Fast, S.B. Michael. Development and validation of a direct enantiomeric separation of pregabalin to support isolated perfused rat kidney studies. Journal of Chromatography B 875 (2008) 148-153.

395. C.G. Evans, J.E. Gestwicki. Enantioselective Organocatalytic Hantzsch Synthesis of Polyhydroquinolines. Organic Letters 11 (2009) 2957-2959.

396. Y. Liu, R.V. Rozhkov, R.C. Larock, T.L. Xiao, D.W. Armstrong. Fast Super/Subcritical Fluid Chromatography Enantiomeric Separations of Dihydrofurocoumarin Derivatives with Macrocyclic Glycopeptide Stationary Phases. Chromatographia 58 (2003) 775-779.

397. P. Busca, F. Paradisi, E. Moynihan, A.R. Maguire, P.C. Engel. Enantioselective synthesis of non-natural amino acids using phenylalanine dehydrogenases 
modified by site-directed mutagenesis. Organic and Biomolecular Chemistry 2 (2004) 2684-2691.

398. C.G. Avila-Ortiz, G. Reyes-Rangel, E. Juaristi. Preparation of both enantiomers of $\beta^{2}$ (3,4-dihydroxybenzyl)- $\beta$-alanine, higher homologues of Dopa. Tetrahedron $\mathbf{6 1}$ (2005) 8372-8381.

399. K. Vedha-Peters, M. Gunawardana, J.D. Rozzell, S.J. Novick. Creation of a BroadRange and Highly Stereoselective D-Amino Acid Dehydrogenase for the One-Step Synthesis of D-Amino Acids. Journal of the American Chemical Society 128 (2006) 10923-10929.

400. I. Ilisz, S. Ballet, K. Van Rompaey, R. De Wachter, D. Tourwé, D.W. Armstrong, A. Péter. High-performance liquid chromatographic separation of stereoisomers of $\mathrm{N}$ phthaloyl-protected amino acids and dipeptidomimetics. Journal of Separation Science 30 (2007) 1881-1887.

401. Z. Pataj, I. Ilisz, R. Berkecz, A. Misicka, D. Tymecka, F. Fulop, D.W. Armstrong, A. Peter. Comparison of performance of Chirobiotic T, T2 and TAG columns in the separation of $\beta^{2}$ - and $\beta^{3}$-homoamino acids. Journal of Separation Science 31 (2008) 3688-3697.

402. Z. Pataj, R. Berkecz, I. Ilisz, A. Misicka, D. Tymecka, F. Fülöp, D.W. Armstrong, A. Peter. High-performance liquid chromatographic chiral separation of $\beta^{2}$ homoamino acids. Chirality 21 (2009) 787-798.

403. X. Zhang, Y. Bao, K. Huang, K.L. Barnett-Rundlett, D.W. Armstrong. Evaluation of dalbavancin as chiral selector for HPLC and comparison with teicoplanin-based chiral stationary phases. Chirality 22 (2010) 495-513.

404. A. Peter, E. Vekes, D.W. Armstrong, D. Tourwe. Enantioseparation by HPLC of imino acids on macrocyclic glycopeptide stationary phases and as their $(S)$ - N-(4Nitrophenoxycarbonyl)phenylalanine methoxyethyl ester derivatives. Chromatographia 56 (2002) S41-S47.

405. A. Peter, E. Vekes, D.W. Armstrong. Effects of temperature on retention of chiral compounds on a ristocetin A chiral stationary phase. Journal of Chromatography A 958 (2002) 89-107.

406. S.M. Staroverov, M.A. Kuznetsov, P.N. Nesterenko, G.G. Vasiarov, G.S. Katrukha, G.B. Fedorova. New chiral stationary phase with macrocyclic glycopeptide antibiotic eremomycin chemically bonded to silica. Journal of Chromatography $A \mathbf{1 1 0 8}$ (2006) 263-267.

407. R. Berkecz, I. Ilisz, G. Benedek, F. Fulop, D.W. Armstrong, A. Peter. Highperformance liquid chromatographic enantioseparation of 2-aminomono- and dihydroxycyclopentanecarboxylic and 2-aminodihydroxycyclohexanecarboxylic acids on macrocyclic glycopeptide-based phases. Journal of Chromatography A 1216 (2009) 927-932.

408. H.J. Bohm, G. Klebe. What can we learn from molecular recognition in proteinligand complexes for the design of new drugs? Angewandte Chemie International Edition (English) 35 (1996) 2588-2614.

409. A.W. Adamson, A.P. Gast. Physical chemistry of surfaces. John Wiley \& Sons, Inc., New York, 1997.

410. V. Sundaresan, R. Abrol. Towards a general model for protein-substrate stereoselectivity. Protein Science 11 (2002) 1330-1339. 
411. R. Thompson, V. Prasad, N. Grinberg, D. Ellison, J. Wyvratt. Mechanistic aspects of the stereospecific interactions of immobilized $\alpha 1$-acid glycoprotein. Journal of Liquid Chromatography \& Related Technologies 24 (2001) 813-825.

412. R. Ledger. Nonaromatic hydroxylation of bupivacaine during continuous epidural infusion in man. Journal of Biochemical and Biophysical Methods 57 (2003) 105114.

413. M.E. Rodriguez Rosas, S. Patel, I.W. Wainer. Determination of the enantiomers of ketamine and norketamine in human plasma by enantioselective liquid chromatography-mass spectrometry. Journal of Chromatography B 794 (2003) 99108.

414. D. Whittington, P. Sheffels, E.D. Kharasch. Brainstem carbachol injections in the urethane anesthetized rat produce hippocampal theta rhythm and cortical desynchronization: a comparison of pedunculopontine tegmental versus nucleus pontis oralis injections. Journal of Chromatography B 809 (2004) 313-321.

415. J. Prabhakaran, V.J. Majo, J.J. Mann, J.S.D. Kumar. Chiral synthesis of (2S,3S)-2-(2morpholin-2-yl-2-phenylmethoxy)phenol. Chirality 16 (2004) 168-173.

416. M.E. Rodriguez-Rosas, J.G. Medrano, D.H. Epstein, E.T. Moolch, K.L. Preston, I.W. Wainer. Determination of total and free concentrations of the enantiomers of methadone and its metabolite (2-ethylidene-1,5-dimethyl-3,3-diphenylpyrrolidine) in human plasma by enantioselective liquid chromatography with mass spectrometric detection. Journal of Chromatography A 1073 (2005) 237-248.

417. A. Garcia-Arieta, F. Abad-Santos, M.A. Rodriguez-Martinez, Y. Varas-Polo, J. Novalbos, N. Laparidis, S. Gallego-Sandin, K. Orfanidis, J. Torrado. An eutomer/distomer ratio near unity does not justify non-enantiospecific assay methods in bioequivalence studies. Chirality 17 (2005) 470-475.

418. T. Benincori, G. Celentano, T. Pilati, A. Ponti, S. Rizzo, F. Sannicolo. Configurationally Stable Molecular Propellers: First Resolution of Residual Enantiomers. Angewandte Chemie International Edition (English) 45 (2006) 6193-6196.

419. Y. Zhang, K. Hidajat, A.J. Ray. Enantio-separation of racemic pindolol on $\alpha_{1}$-acid glycoprotein chiral stationary phase by SMB and Varicol. Chemical Engineering Science 62 (2007) 1364-1375.

420. O. Illa, M. Arshad, A. Ros, E.M. McGarrigle, V.K. Aggarwal. Practical and Highly Selective Sulfur Ylide Mediated Asymmetric Epoxidations and Aziridinations Using an Inexpensive, Readily Available Chiral Sulfide. Applications to the Synthesis of Quinine and Quinidine. Journal of the American Chemical Society 132 (2010) 18281830.

421. M.X. Wang, G. Lu, G.J. Ji, Z.T. Huang, O. Meth-Cohn, J. Colby. Enantioselective biotransformations of racemic $\alpha$-substituted phenylacetonitriles and phenylacetamides using Rhodococcus sp. AJ270. Tetrahedron: Asymmetry 11 (2000) 11231135.

422. K. Harada, Q. Yuan, M. Nakayama, A. Sugii. Effects of organic modifiers on the chiral recognition by different types of silica-immobilized bovine serum albumin. Journal of Chromatography A $\mathbf{7 4 0}$ (1996) 207-213.

423. W.H. Lee, K.J. Kim, M.G. Kim, S.B. Lee. Enzymatic resolution of racemic ibuprofen esters: Effects of organic cosolvents and temperature. Journal of Fermentation and Bioengeneering 80 (1995) 613-615. 
424. E. Brandsteterova, K. Marcincinova, J. Lehotay, A. Zbojova, J. Halko. HPLC analysis of optical isomers of leucovorin and methotrexate using achiral-chiral system. Neoplasma 40 (1993) 241-245.

425. R.J. Mullin, D.S. Duch. Preparation of a chiral matrix Resolution of $(6 \mathrm{R}, \$)-\mathrm{N} 5$ formyltetrahydrofolate. Journal of Chromatography A 555 (1991) 254-259.

426. J. Haginaka, H. Takehira. Separation of enantiomers on a chiral stationary phase based on ovoglycoprotein: II. Comparison of chiral recognition properties with crude ovomucoid. Journal of Chromatography A 777 (1997) 241-247.

427. M. Suzuki, Y. Yanagawa, H. Iwasaki, H. Kanda, K. Yanagihara, H. Matsumoto, Y. Ohara, Y. Yazaki, R. Sakoda. First systematic chiral syntheses of two pairs of enantiomers with 3,5-dihydroxyheptenoic acid chain, associated with a potent synthetic statin NK-104. Bioorganic and Medicinal Chemistry Letters 9 (1999) 2977-2982.

428. J.S. Albert, D. Aharony, D. Andisik, H. Barthlow, P.R. Bernstein, R.A. Bialecki, R. Dedinas, B.T. Dembofsky, D. Hill, K. Kirkland, G.M. Koether, B.J. Kosmider, C. Ohnmacht, W. Palmer, W. Potts, W. Rumsey, L. Shen, A. Shenvi, S. Sherwood, P.J. Warwick, K. Russell. Design, synthesis and SAR of Tachykinin antagonists: modulation of balance in $\mathrm{NK}_{1} / \mathrm{NK}_{2}$ receptor antagonist activity. Journal of Medicinal Chemistry 45 (2002) 3972-3983.

429. D. Ohman, B. Norlander, C. Peterson, F. Bengtsson. Simultaneous determination of reboxetine and $O$-desethylreboxetine enantiomers using enantioselective reversed-phase high-performance liquid chromatography. Journal of Chromatography $A$ 947 (2002) 247-254.

430. F. Pellati, S. Benvenuti, M. Melegari. Enantioselective LC analysis of synephrine in natural products on a protein-based chiral stationary phase. Journal of Pharmaceutical and Biomedical Analysis 37 (2005) 839-849. 